Florida International University

FIU Digital Commons

$7-7-2020$

\title{
Disaster Aid, Non-Governmental Organizations (NGOs), and Development: A Critical Analysis of the Post 2010-Disaster Aid In Haiti
}

Jean Max Charles

Florida International University, jchar077@fiu.edu

Follow this and additional works at: https://digitalcommons.fiu.edu/etd

Part of the Sociology Commons

\section{Recommended Citation}

Charles, Jean Max, "Disaster Aid, Non-Governmental Organizations (NGOs), and Development: A Critical Analysis of the Post 2010-Disaster Aid In Haiti" (2020). FIU Electronic Theses and Dissertations. 4456. https://digitalcommons.fiu.edu/etd/4456

This work is brought to you for free and open access by the University Graduate School at FIU Digital Commons. It has been accepted for inclusion in FIU Electronic Theses and Dissertations by an authorized administrator of FIU Digital Commons. For more information, please contact dcc@fiu.edu. 


\section{FLORIDA INTERNATIONAL UNIVERSITY}

Miami, Florida

DISASTER AID, NON-GOVERNMENTAL ORGANIZATIONS (NGOS)s, AND

DEVELOPMENT: A CRITICAL ANALYSIS OF THE 2010 POST-DISASTER AID IN

HAITI

A dissertation submitted in partial fulfillment of

the requirements for the degree of

DOCTOR OF PHILOSOPHY

in

GLOBAL SOCIOCULTURAL STUDIES

by

Jean Max Charles 
To: Dean John F Stack, Jr.

Steven J. Green School of International and Public Affairs

This dissertation, written by Jean Max Charles, and entitled Disaster Aid, Non-

Governmental Organizations (NGOs), and Development: A Critical Analysis of the Post2010 Disaster Aid in Haiti, having been approved in respect to style and intellectual content, is referred to you for judgment.

We have read this dissertation and recommend that it be approved.

$\begin{array}{r}\hline \text { Benjamin Smith } \\ \hline \text { Qing Lai } \\ \hline \text { Ana M. Bidegain } \\ \hline \text { Percy C. Hintzen, Major Professor }\end{array}$

Date of Defense: July 7, 2020

The dissertation of Jean Max Charles is approved.

Dean John F Stack, Jr.

Steven J. Green School of International and Public Affairs

Andrés G. Gil

Vice President for Research and Economic Development and Dean of the University Graduate School

Florida International University, 2020 


\section{ACKNOWLEDGMENTS}

I want to express my sincere gratitude to my dissertation committee members Dr. Percy Hintzen, Dr. Smith Benjamin, Dr. Ana Bidegain, and Dr. Lai Qing. It has especially been a privilege for me to work under the guidance of professor Percy Hintzen, from whom I continue to learn. The journey was difficult, but the results vindicate the efforts. Dr. Bidegain offered relevant comments on the research project, and I am thankful for her input. A special thanks to Dr. Smith, who granted me a teaching assistantship at the time I needed it the most. I am grateful to the Fulbright U.S. Scholar Program for selecting me as a Fulbright Scholar for Haiti (2019-2020). This grant helped me tremendously as I completed the dissertation. I am also grateful to the Graduate and Professional Student Committee (GPSC) for a travel grant during my fieldwork in Haiti.

A special thanks to Rosalie Schurman, my former doctorate classmate. She worked on the project from its inception. She proofread, offered many important comments, and helped me to refine the work. I am also grateful to Samantha Bean and my friend, Nadège Joassaint-Meyer, who diligently worked to refine the final document. Thanks to Maria Barbero, also my doctorate classmate, for her advice and suggestions. I also want to thank the team who conducted the survey in Haiti. I am especially indebted to Abnel Désamours and Pierre Anthony Garraud. The survey could not have been possible without the support, guidance, and expertise of Dr. Qing. I will be forever grateful to you. A special thanks to all my interviewees, the community organizations, and the NGOs who welcomed me and shared with me a wealth of information.

I am also indebted to all my family and friends who supported me throughout this project; especially my mother, Martha, my brothers Pèdre, Edward, Woody, and Hémeck, 
and my dear friend Oliver Thompson. To Johnathon Shetrit, my 15-year-old computer genius friend who formatted the work and the tables, I owe many thanks.

My wife Emilie and my two sons Max and Berkley have been of an extraordinary source of encouragement. This dissertation would not have been possible without their support. They have my love as well as my sincere thanks. 


\begin{abstract}
OF THE DISSERTATION
DISASTER AID, NON-GOVERNMENTAL ORGANIZATIONS (NGOs), AND

DEVELOPMENT: A CRITICAL ANALYSIS OF THE POST-DISASTER AID IN
\end{abstract}

HAITI

by

Jean Max Charles

Florida International University, 2020

Florida, Miami

Professor Percy C. Hintzen, Major Professor

This dissertation investigates both the effectiveness and the limitations of NonGovernmental Organizations (NGOs) aid as it relates to efforts to provide sustainable development outcomes in the wake of disasters. Focusing on the case of Haiti, and the billions of dollars of disaster aid that the country received through NGOs for relief and reconstruction of the country in the wake of the 2010 magnitude 7.0 earthquake, this dissertation explores ways in which the delivery and management of disaster aid can be organized to produce long-term sustainable results. My research is formulated around the argument that, to produce long-term outcomes, disaster aid and relief must make development a centerpiece of its intervention in order to reduce future vulnerability and build resilient communities. I argue that disjunctures in the post-revolutionary governance of Haiti created conditions of precarity, vulnerability, and preempted possibilities for resilience. The explanation rests in the policies and practices of powerful domestic and foreign actors with vested interests in maintaining conditions of underdevelopment. This explains the failure of the country to effectively respond to extreme natural events such as 
earthquakes and hurricanes, thereby transforming them into pervasive natural disasters. Using a mixed method approach that combines institutional ethnography of three NGOs, semi-structured interviews, focus groups, and a survey of 889 households in Port-auPrince, I document the failure of the post-disaster recovery. I argue that to create the conditions for structural transformation following a disaster, NGOs need to work with local governments in the face of an ineffective state. They need to do so in ways that empower the subaltern in the communities, and they need to build in resilience into their response. I make a general case that when authority is devolved to the local level, communities can escape the forms of disjuncture that create precarity and vulnerability operative at the national level of governance. This creates possibilities for genuine development transformation that bring with them resilience to natural events that produce disasters. 


\section{TABLE OF CONTENTS}

CHAPTER

PAGE

Chapter One: Introduction, Methods, Theoretical Framework, and Background ..............1

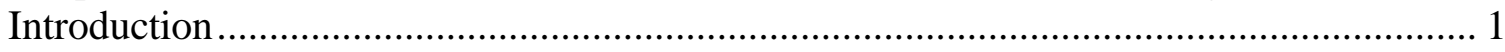

Research Objectives and Expected Impact ............................................................ 3

Methods and Research Design ......................................................................... 5

Institutional Ethnography and Archival Research .................................................. 5

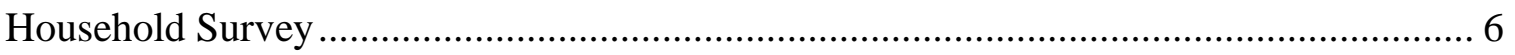

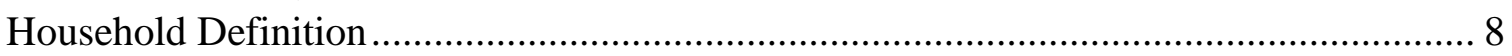

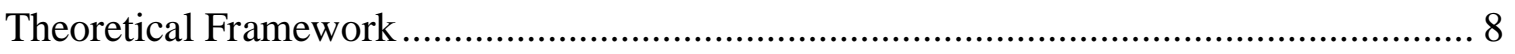

Neoliberalism and Haiti Vulnerability to Disaster.................................................... 8

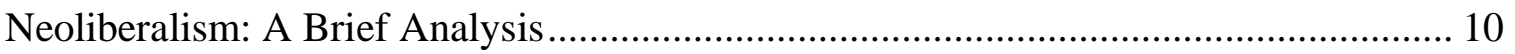

Neoliberal Policies, NGOs, and the Implications on the State ..................................... 13

Neoliberalism: When the "Un-usable" Becomes "Usable" ........................................... 15

Haiti: Post-Revolutionary History and Underdevelopment ........................................... 19

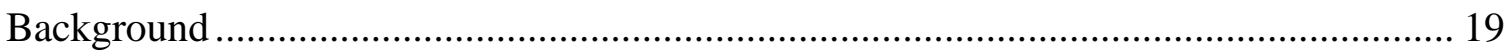

International Factor: The Legacy of The Past........................................................... 21

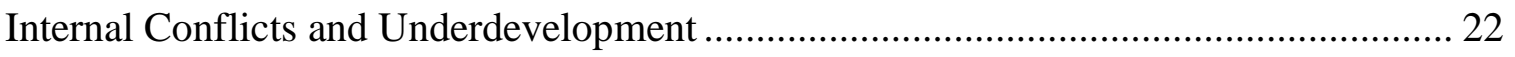

The Case of Port-au-Prince: Population Density and Unplanned Growth ...................... 25

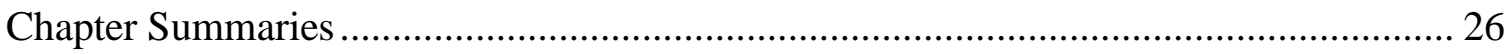

Chapter Two: Disasters Relief, NGOs, and Development: A Scholarly Focus................29

Disaster Relief: Context and Evolution ............................................................... 30

Living Dangerously: Climate Change and the Rise of Natural Disasters ....................... 30

The Changing Relationship Between Disaster and Development ................................. 31

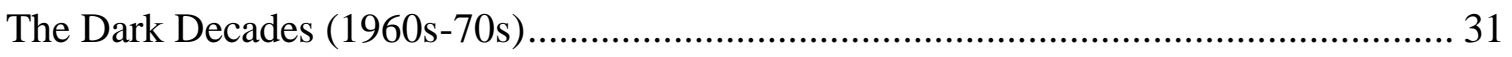

Emergence of Disaster Behavior and Crisis Management (1970s) ............................... 33

Paradigm Shift in Disaster Studies (1980s-90s) ........................................................... 34

Disaster, Climate Change, and Development: A Global Concern .................................. 36

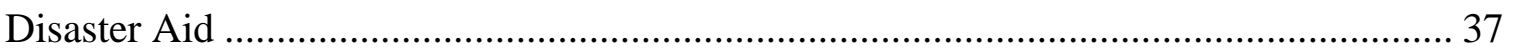

NGOs, Classification, and Potential Contribution to Development .............................. 41

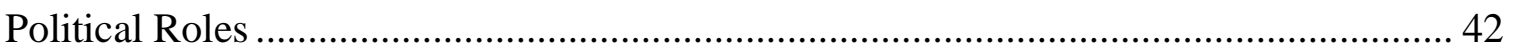

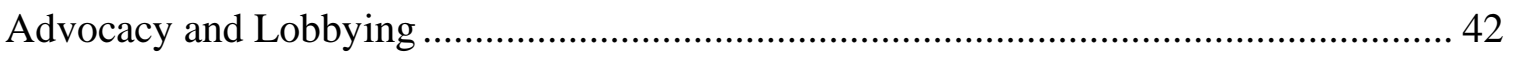

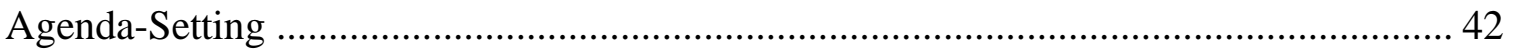

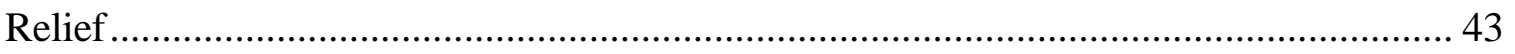

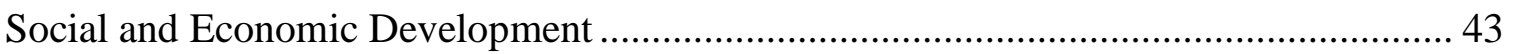

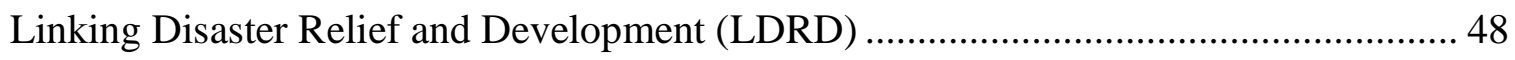

Theorizing Resilience in a Post-disaster Context .................................................. 51 


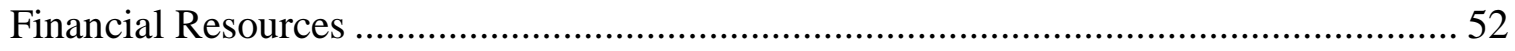

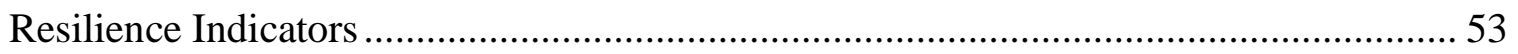

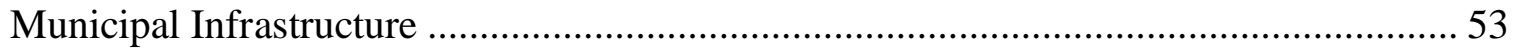

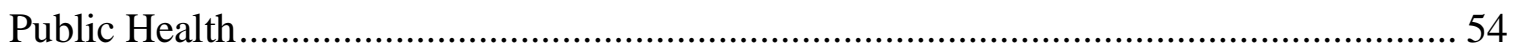

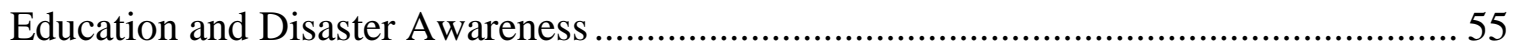

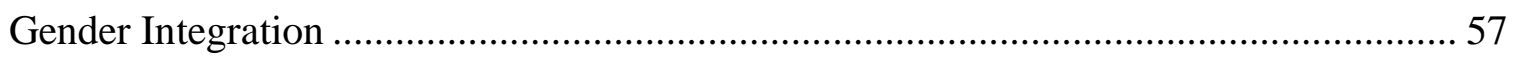

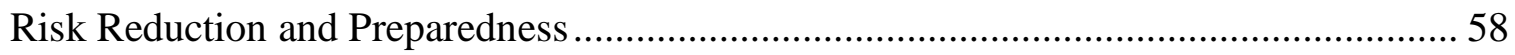

Building Resilience Through Disaster Relief: A Development Goal ............................... 59

Toward a New Development Perspective: The Role of NGOs …………........................ 60

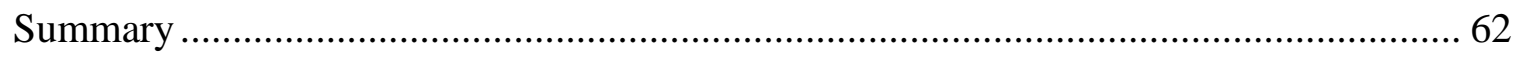

Chapter Three: The Parallel State: Neoliberalism in Haiti and the Reliance on NGOs ....64

The 1980s: The Beginning of Depeasantization process in Haiti ....................................... 64

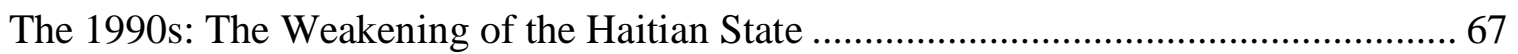

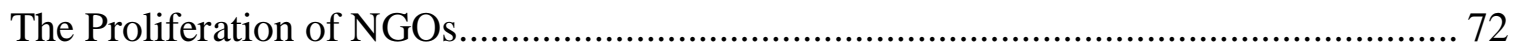

The First wave and the Increase Presence of NGOs in Haiti.......................................... 73

The Second Wave and The Shift to A Complete Reliance on NGOs................................ 74

NGOs in Haiti: The Construction of a Parallel State ..................................................... 76

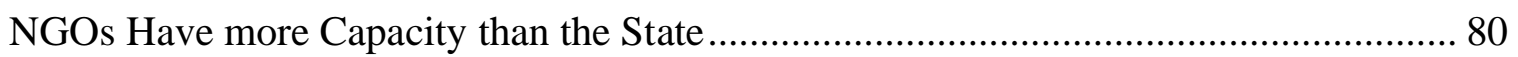

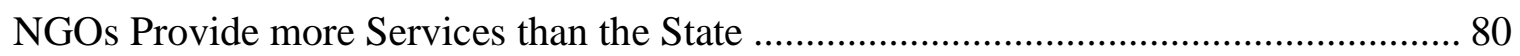

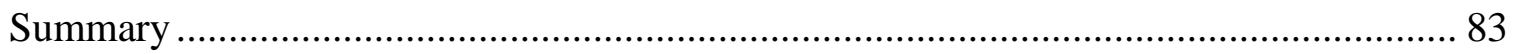

Chapter Four: Haiti Before the Earthquake: The Vulnerability to Disaster .......................85

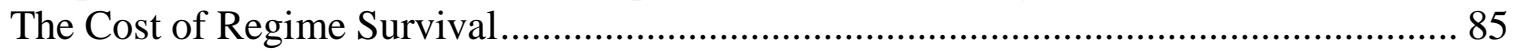

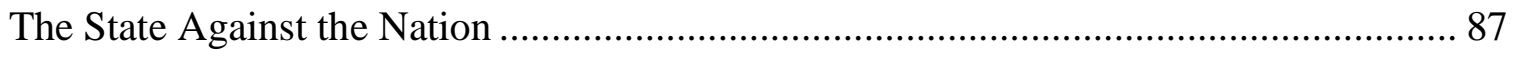

Weak Economy, Structural Poverty, and Vulnerable Population .................................... 101

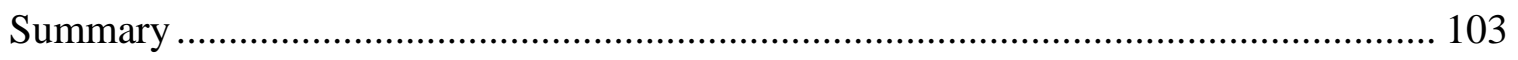

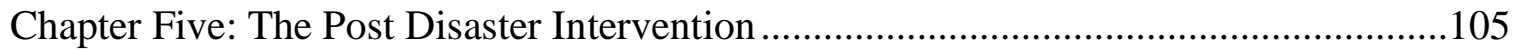

The International Donors Conference......................................................................... 108

International Donors Conference: Towards a New Future for Haiti, March 31, 2010 ... 111

The UN Secretary Ban Ki-moon's Opening Statement:............................................. 112

The Resilience Survey: Findings and Analysis ………………………..................... 115

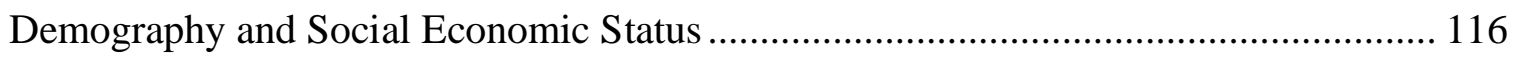

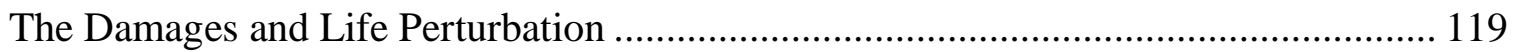

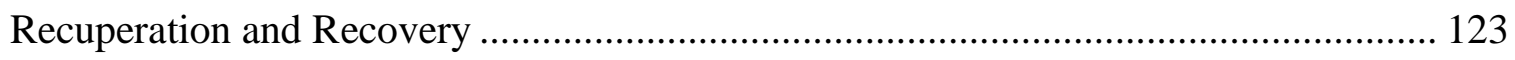

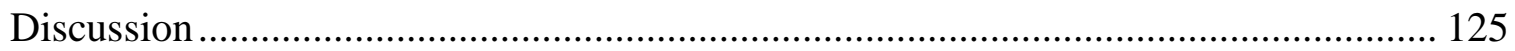

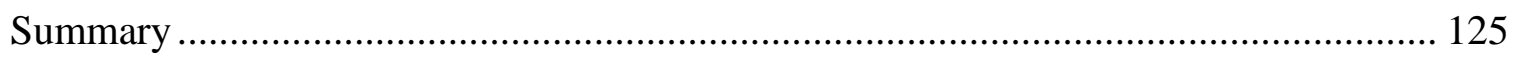

Chapter Six: NGOs and Disaster Aid: Towards a New Approach ..................................127

Functional Limit of NGO Intervention in Haiti ........................................................... 127 
Reinforcing Local NGOs and the Collaboration with Local Governments ................... 129

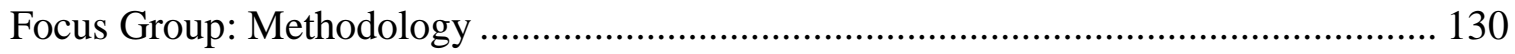

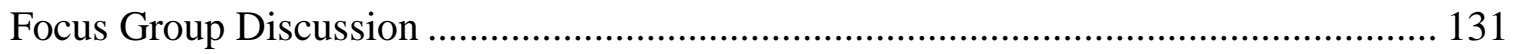

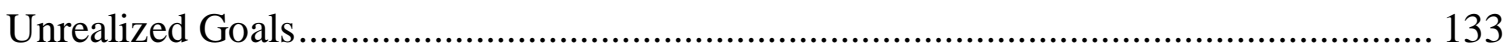

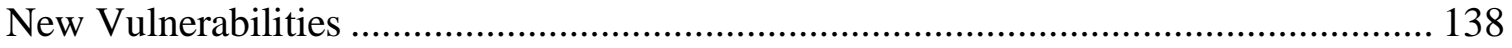

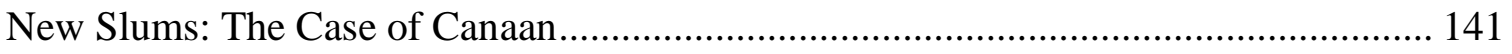

Ringing the Bell: Public Health and the Next Disaster in Haiti ................................... 144

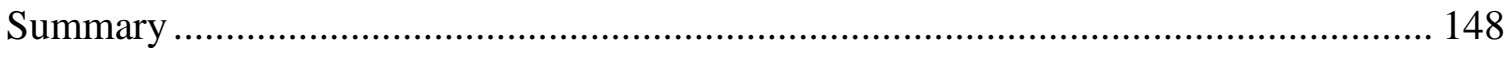

Chapter Seven: Unending Relief and Increased Vulnerabilities ..................................150

Inadequate efforts to Increase Capacities and Reduce Vulnerabilities .......................... 151

Increase funding for Development Agencies........................................................ 156

Building Resilience into Projects ..................................................................... 160

Lack of Collaboration Between Aid Agencies/NGOs and Local Governments ............. 161

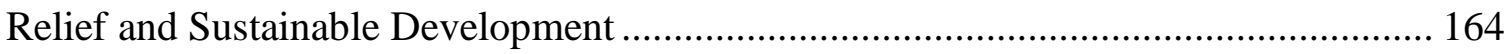

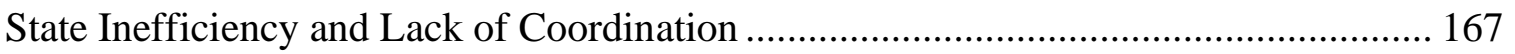

Between Frustration and Hope......................................................................... 172

Case Study One: Income Generation Activities (IGA) .............................................. 174

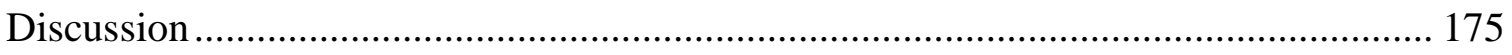

Case Study Two: Disaster Prevention and Preparedness........................................... 177

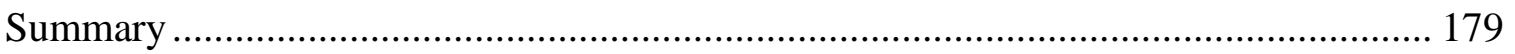

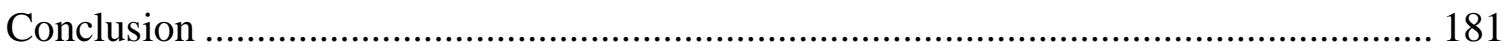

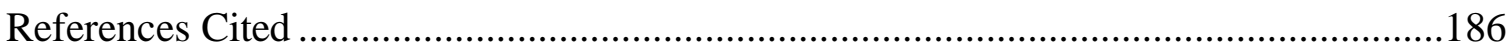

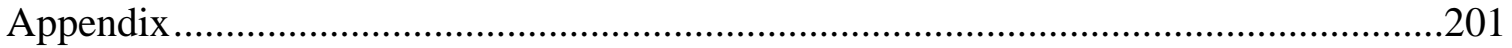

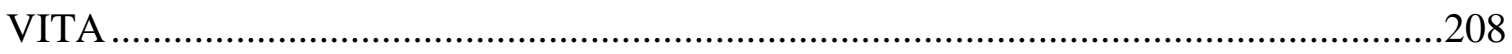




\section{LIST OF TABLES}

TABLE

PAGE

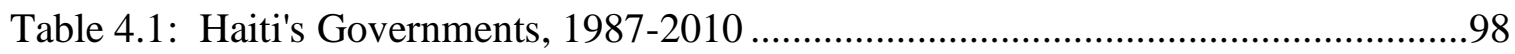

Table 4.2: Summary of the Last three Disasters in Haiti Before the 2010 Earthquake ...102

Table 5.1: Sample Description by Commune .............................................................117

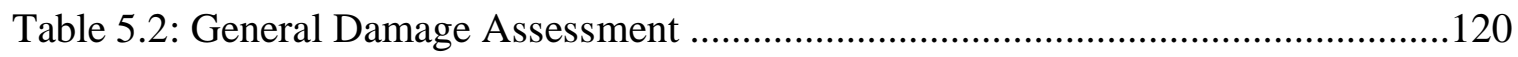

Table 5.3: Long-term Health Perturbances ........................................................... 121

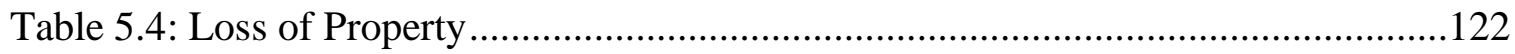

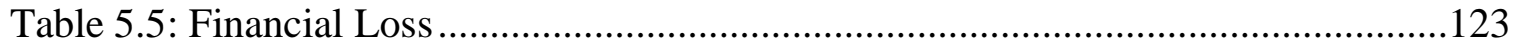

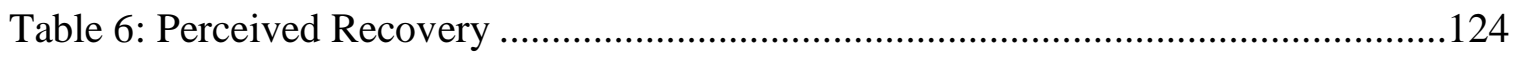

Table 7.1: List of NGOs, Field Intervention, and Philosophy ....................................151 


\section{LIST OF FIGURES}

FIGURE

PAGE

Figure 5.1: The National Palace in Port-au-Prince. ........................................................106

Figure 5.2: International Donors' Conference, Toward a New Future for Haiti. ............109

Figure 5.3: Money Raised and Disbursed to Haiti Between 2010- 2012 ......................110

Figure 5.4: Map of Port-au-Prince with the location of the three communes surveyed. .116

Figure 6.1: Palais de Justice (Justice Palace) before the earthquake

Figure 6.2: Palais de Justice (Justice Palace) in Haiti after the earthquake.

Figure 6.4: The model of the New Parliament building. 136

Figure 6.7: Photo exposing the risk of a landslide in Canaan. .143

Figure 6.8: Action Plan for Urban Restructuration of Canaan. 144

Figure 6.9: Ady Dumé, 38, street medications vendor. 146

Figure 7.1: Drainage filled with debris and trash near Cité Soleil. 160

Figure 7.2: Homes built by GOAL in Turgeau, Port-au-Prince 163

Figure 7.3: School of Eglise Baptiste de Salem. .173

Figure 7.4: Shoe Shop of a Compassion International IGA program beneficiary. .176 


\section{LIST OF ABBREVIATIONS AND ACRONYMS}

\begin{tabular}{ll} 
ALNAP & $\begin{array}{l}\text { Active Learning Network for Accountability and Performance in } \\
\text { Human Action }\end{array}$ \\
BRAC & Bangladesh Rural Advancement Committee \\
CIDA & Caribbean Catastrophe Risk Insurance Facility \\
CARE & Canadian International Development Agency \\
CRS & Cooperative for American Relief Everywhere \\
COOPI & Catholic Relief Service \\
CNSA & Cooperation International \\
DDR & National Coordination of Food Security \\
EERP & Disaster Risk Reduction \\
ECHO & Emergency Economic Recovery Program \\
ECVMAS & European Commission Humanitarian Aid \\
EERP & Enquêtes sur les Conditions de Vie des Ménages Après le Séisme \\
EPI & Economic Recovery Program \\
EU & Expanded Program on Immunization \\
FAO & European Union \\
FUNCOL & Fund and Agriculture Organization of the United States \\
GDP & Foundation of Colombian Communities \\
GOH & Gross Domestic Product \\
IDB & Haitian Institute of Statistics and Informatics \\
\hline
\end{tabular}




\begin{tabular}{|c|c|}
\hline IFS & International Financial Institutions \\
\hline IMF & International Monetary Funds \\
\hline INGO & International Non-Governmental Organizations \\
\hline INS & Immigration and Naturalization Service \\
\hline ISDR & International Strategy for Disaster Reduction \\
\hline IPCC & Panel on Climate Change \\
\hline KRIFAH & Kri Fanm \\
\hline LRRD & Linking Relief, Rehabilitation and Development \\
\hline NGO & Non-Governmental Organizations \\
\hline OCHA & Office for the Coordination of Humanitarian Affairs \\
\hline ODSETAD & $\begin{array}{l}\text { Organization for Development and Technical Support for Haitian } \\
\text { Artisans }\end{array}$ \\
\hline OECD & Organization for Economic Cooperation and Development \\
\hline OFDA & Office of the United States Foreign Disaster Assistance \\
\hline OSGSA & Office of the Secretary General's Special Advisor \\
\hline RFPC & Group Professional Women in construction \\
\hline SAP & Structural Adjustment Policy \\
\hline SDE & Primary Unit Selection \\
\hline SDG & Sustainable Development Goals \\
\hline UN & United Nations \\
\hline UNDP & United Nations Development Program \\
\hline UNFPA & United Nations Population Fund \\
\hline UNICEF & United Nations Children's Funds \\
\hline
\end{tabular}


USAID

VWH
United States Agency for International Development

Voice of Women in Haiti 


\section{Chapter One: Introduction, Methods, Theoretical Framework, and Background}

\section{Introduction}

This dissertation investigates both the effectiveness and the limitations of NonGovernmental Organization (NGO) aid as it relates to efforts to provide sustainable development outcomes in the wake of disasters. Focusing on the case of Haiti, and the billions of dollars of disaster aid that the country received through NGOs for relief and reconstruction of the country in the wake of the 2010 magnitude 7.0 earthquake, this dissertation explores ways in which the delivery and management of disaster aid can be organized to produce long-term results and limit the possibility of future disasters.

In January 2010, a massive 7.0 magnitude earthquake struck Haiti. According to the Haitian government, more than 220,000 people lost their lives, 300,000 were injured, and 1.3 million became homeless $(\mathrm{GOH}, 2010)$. The earthquake also severely damaged the country's infrastructure; an estimated 60 percent of the country's public services were destroyed, including 80 percent of schools and 50 percent of hospitals $(\mathrm{GOH}, 2010)$. In the wake of the earthquake, there was an outpouring of global support as the international community immediately assisted the devastated country. At the International Donors Conference Toward a New Future for Haiti, held two months after the catastrophe, donors pledged $\$ 9$ billion USD for the country's recovery and reconstruction (UN, 2010). The Haitian government, known for its ineffectiveness, was excluded from access to and management of these funds (Pierre Louis, 2012; Zanotti, 2011). Thus, the money was disbursed directly to NGOs. 
The decision to disburse relief and reconstruction aid through NGOs proved ineffective. A decade after the earthquake, Haiti is still struggling desperately. According to a household survey (ECVMAS, 2012), about 2/3 of Haitians live under the national poverty line, earning a daily income of less than 2.4 U.S. Dollars (USD), and 25 percent live under the national extreme poverty line of 1.23 USD per day. The Secretary-General's 2017 report on the United Nations Stabilization Mission in Haiti stressed that 2.35 million (of 10.4 million) people in Haiti are in need of immediate assistance, while more than 143,110 are estimated to be suffering from acute malnutrition. The World Bank reported in 2017 that Haiti is still vulnerable to natural disasters, with more than 90 percent of the population at risk.

Yet, compared with year 2000 statistics, the World Bank has reported modest improvements in the social and economic conditions in Haiti (Singh \& Barton-Dock, 2015). According to the World Bank in 2012, poverty declined from 31 percent to 24 percent between 2000 and 2012. Extreme poverty also fell from 21 percent to 12 percent in urban areas. However, findings (Singh \& Barton-Dock, 2015) indicate that this improvement was largely a result of increased remittances from abroad, from 42 percent in 2000 to 69 percent in 2012. Also, income inequality has remained stagnant since 2001. The richest 20 percent are still earning more than 64 percent of the total income of the country (Singh \& Barton-Dock, 2015).

Given the poor results of Haiti's post-disaster aid, it is clear that disaster aid does not always produce positive outcomes and long-term transformation. Numerous scholars (Anderson and Woodrow, 1989; Delica-Willison \& Willison, 2004; Hilhorst \& Bankoff, 2004) have argued that even well-intentioned relief can create unforeseen vulnerabilities 
and make socioeconomic conditions even worse. My research is formulated around the argument that, to produce long-term outcomes, disaster aid and relief must make development a centerpiece of its intervention in order to reduce future vulnerability and build resilient communities. My dissertation aims to answer three main questions: 1) Do NGOs have the capabilities to conduct disaster relief in ways that can produce sustainable development outcomes? 2) How must disaster aid be provided and managed to lower people's vulnerabilities to disaster and increase their capacities? 3) To what extent was disaster resilience built into the post-quake NGO-provided relief in Haiti?

\section{Research Objectives and Expected Impact}

This dissertation intends to investigate the effectiveness of disaster relief in the wake of the January 2010 earthquake in Haiti. In a broader perspective, it aims to analyze the role of NGOs in disaster relief and management, and the possibility of their involvement in producing sustainable development outcomes. It is useful for this research to situate my theoretical understanding of the concept of development, map how relief could build resilient communities as part of development goals, and assess the role of NGOs in this process. The dissertation comes with the prospect of breaking new grounds by linking longterm development goals with building resilience to disasters.

This dissertation advances several fields of inquiry, including the sociology of development, disaster and resilience studies, the study of NGOs, disaster management and preparedness, and political economy. It contributes to rapidly expanding literature that links disaster relief and development. In its engagement with the fraught issue of development and resilience, the study also contributes to a new practical paradigm; it 
articulates a locally centered strategy combined with the assistance of NGOs and showcases the potential efficacy of this combination to realize developmental goals. The study promotes the idea of building resilient communities as the primary goal of development projects in disaster-prone areas. This research will also extend to NGOs' dayto-day operations in the wake of disaster, viewing such organizations as engines of development, as opposed to perennial relief management organizations.

This research will also make significant contributions to understanding the ways in which NGOs can successfully deliver and implement disaster aid in the context of a weakened state. Building on the lessons learned from past interventions of NGOs, this research investigates both the limits and possibilities of NGO-provided aid. It also frames what successful delivery of disaster aid entails, and thus focuses on gaining a better understanding of the relationship between disaster aid and development. Drawing on the argument that disasters occur because of lack of development, this research argues that successful delivery of disaster aid must be development-oriented. This requires reducing vulnerabilities, increasing capacities, and building resilient communities. Finally, this is transformative research that can have immediate and significant policy implications as related to NGOs in Haiti, the way aid has been delivered and implemented, and the pursuit of ongoing development goals. The research will allow the international community to make better investments in disaster relief and aid in developing countries, and to save funds in the future by pursuing the creation of disaster-resilient communities as a fundamental development goal. 


\section{Methods and Research Design}

This study focuses on Carrefour, the commune of Port-au-Prince, and Delmas. Data for this research was gathered through institutional ethnography, archival documents, semistructured interviews, and a household survey. I collected the data in three phases over a period of ten months, from August 2018 to May 2019.

\section{Institutional Ethnography and Archival Research}

I investigated three NGOs and conducted documentary archival research. The three NGOs - Compassion International, Cooperation International (COOPI), and GOAL, an Irish $\mathrm{NGO}$ - are working in the areas most affected by the earthquake: Port-au-Prince, Carrefour, and Delmas. During this period, I participated in field activities with NGO workers, interviewed beneficiaries, and visited projects on the ground. This phase was a great opportunity not only for me to meet people, but also to collect important documents for my research. Specifically, I collected a wealth of documents on project proposals, implementation reports, project evaluations, and budgets.

\section{Semi-structured Interviews and Focus Groups}

I conducted semi-structured interviews with top NGO directors and other relevant leaders. I interviewed international NGO consultants and high-ranking NGO officials, two of whom worked as country directors of international NGOs in Haiti. Most of my contacts with NGOs were facilitated by the Cadre de Liaison Inter-Organizations (CLIO) (Inter- 
Organization Liaison Framework), an association of organizations created in 2005 that tries to coordinate the activities of sixty-six Haitian and foreign organizations.

I also interviewed local NGOs and religious voluntary organizations. Particularly, in the guesthouse where I stayed during my fieldwork, I met with charitable organization leaders from Canada and the U.S. who frequently delivered aid to Haiti post-earthquake. I interviewed mayors of different municipalities and other high-profile local and national government officials, university professors and international charity organizations.1

I conducted focus group discussions to complement the data gathered from the institutional ethnography and individual interviews. The CLIO also facilitated the contacts with the community organizations. I organized the focus groups in order to collect grassroots opinions of the NGOs' intervention after the earthquake, as well as to critically evaluate the intervention's level of success in the eyes of the community. I met with three community organizations, two of which were geared toward women - Kri Fanm Haiti (KRIFAH) and Sauve Fanm (Save the Women). The other group discussion was conducted with a very well-known community organization: Organisation for Development et Encadrement Technique des Artisans d'Haiti (ODSETAD) (Organization for Social Development and Technical Support of Haitian Artisans).

\section{Household Survey}

I surveyed 889 households in three cities: Port-au-Prince, Carrefour, and Delmas. The objective of the survey was to measure the "perceived level of resilience" of the population

1 They are voluntary organizations from the U.S. and Canada. They are not registered in Haiti as NGOs 
and was conducted by a team of eleven individuals trained in research and data collection. The team was led by two economist-statisticians, formerly of the Coordination Nationale de la Sécurité Alimentaire (CNSA, or National Coordination for Food Security) in Haiti.

To select the households, the survey utilized the Expanded Program on Immunization (EPI) sampling method adopted by the World Health Organization (WHO). The EPI is a cluster-sampling method that is often used to assess health and basic needs in communities affected by disasters (Malilay, Flanders, Brogan, and Flanders, 1996). The EPI method has been revisited and widely used in many post-disaster context surveys Chao, Li-Wei et al. (2012). Eighty clusters, a number based on the Primary Unit Selection (SDE) procedure established by the Haiti Institute of Statistics (HIS), were chosen with a probability proportionate to their size, and ten households were surveyed in each of the selected clusters.

Primary Unit Selection Procedure (SDE)

The Haiti Institute of Statistics (HIS) has a computer file containing the list of SDEs (Primary Unit Selection Procedures) for the three municipalities covered by the study. In this file, each SDE appears with all its identifiers (region, department, and identification code), household size, population, and type of area (urban, rural). The boundaries of each SDE are clearly identifiable on maps created to facilitate surveyors' deployment. The eighty clusters were drawn with a probability proportionate to household size. 


\section{Household Definition}

I define "household" as any residential family unit that eats together regularly. If there are multiple groups living in the same structure, we considered all who share meals as one household. If there are separate families in one shelter that all eat apart from one another, each was counted as an individual household. For apartment buildings, each apartment was considered a household. For structures with several levels, we considered any level that had a separate family as a household. For example, a structure with three levels and three different families living on each level would be counted as three households.

This survey allowed me to measure the "perceived level of resilience" of Haiti's population. As with most descriptive surveys, I employed it to make inferences from people's responses, which indicated whether disaster relief has produced resilience.

\section{Theoretical Framework}

The theoretical framework that guides this research draws on neoliberalism and the consequences of its implementation.

\section{Neoliberalism and Haiti Vulnerability to Disaster}

According to the World Bank report Haiti: Toward a New Narrative (Singh \& BartonDock; 2015):

The Haitian population is one of the most exposed in the world to natural disasters: hurricanes, floods and earthquakes. Haiti has a higher number of disasters per km2 than the average of the Caribbean countries... disasters tend to affect 
disproportionately the poorest and the marginal populations settling in flood zones and coastal areas, in particular in the case of tropical storms where almost 50 percent of damages and losses to the productive sectors have been concentrated in the agricultural sector (Singh \& Barton-Dock; 2015; p.21).

Among the Caribbean countries, Haiti is the most vulnerable to hazards. The losses and damages resulting from natural disasters in Haiti are far greater than those in many of the other Caribbean countries. From 1971- 2014, Haiti has experienced 137 natural disasters (the 2010 earthquake excluded), which resulted in 23,427 deaths and an average GDP loss of 1.776 percent (Singh \& Barton-Dock 2015, p. 22). During the same period, there have been fewer casualties due to natural disasters in the Dominican Republic, Jamaica, Nicaragua, Honduras, El Salvador, Guatemala, Costa Rica, and Panama combined (OFDA/CRED). Haiti's high vulnerability to natural disasters is not, however, inherent to the country's geography - it is not an intrinsic feature of its natural and geographical conditions. Thus, it is imperative to compare Haiti and the Dominican Republic - the two countries share the same island. Haiti has had twice as many natural disasters from 1971 to 2014 as the Dominican Republic. According to the World Bank Haiti's greater vulnerability to disasters is reflected in the consequences of these events (deforestation, floods, etc.) in terms of both human and economic losses. These reflect the inadequacy of drainage, large populations settling in flood zones, and the lack of sound building codes (Singh \& Barton-Dock, 2015, p. 22).

While this argument is justified, I argue that the high vulnerability must be analyzed in a political-economic context. It is a result of failed neoliberal development policies implemented in Haiti in the 1980s (Dupuy, 1997, 2005; Schuller, 2009, 2012). The 
implementation of such policies had two serious political-economic implications: the weakening of the state and a complete reliance on NGOs (Ferguson, 2006). As Schuller notes regarding the 2010 earthquake in Haiti:

The earthquake exposed the weakness of the state... The state has no ability to prevent the disaster or coordinate the relief efforts. The government had been weakened since the mid-1990s by donor's policies of giving their aid directly to NGOs. Even before the earthquake, more than 80 percent of the health clinics and 90 percent of schools were private, run by individuals, missions, and NGOs particularly the large food distribution agencies like World Vision, CARE (Cooperative for American Relief Everywhere), or Catholic Relief Services became parallel states, even marking off territory into their area (Schuller, 2012, p.6).

I will analyze the political implications of neoliberalism in Haiti in Chapter Three. However, it is important here to outline a brief history of neoliberalism.

\section{Neoliberalism: A Brief Analysis}

Neoliberalism, as a development model, involves the restructuring of domestic economies to expand their markets. It rests on the assumptions of neoclassical economics, which eclipsed the interventionist state model (Ferguson, 2006; Robinson, 2014). Neoliberalization de-emphasizes the social goals of national development while emphasizing participation in the world economy through tariff reduction, export promotion, financial deregulation, and relaxation of foreign investment rules (McMichael, 2008). These policies reformulate development to be that of a global project. Neoliberal ideas may be traced from 
the beginning of the twentieth century, through Karl Polanyi's analysis of the free market mechanism (Polanyi, 1957), although neoliberalism ideas were adopted in the wake of classical economics theorists such as Adam Smith and David Ricardo. It was through economists such as Milton Friedman and Gary Berker that they became fully articulated in the 1960s as a dominant economic school of thought. Politically, neoliberalism came to the forefront of Western economic doctrine through Ronald Reagan and Margaret Thatcher in the 1980s. Both leaders saw government as an obstacle to economic freedom, not a solution. Thatcher in England and Reagan in the U.S. attacked what they called "big government" and the welfare state. Their policies focused on restructuring public sector activities by increasing the role of corporations and the private sector in order to achieve greater economic efficiency (Ong, 1999, 2006).

In the 1980s, neoliberalism began to be exported to the Third World as a set of instruments for development. Neoliberal policies were collectively referenced as the Washington Consensus, a term first used in 1989 by the economist John Williamson "to refer to the policy reforms imposed when debtor countries in Latin America were called on to 'set their houses in order' and submit to strong conditionality" (Peet \& Hartwick 2009, p.84). Those policy reforms mainly included: 1) fiscal discipline, 2) reducing public expenditures, 3) tax reform, 4) financial liberalization, 5) unified and competitive exchange rates, 6) trade liberalization, 7) openness to direct foreign investment, 8) privatization, 9) deregulation, and 10) secure property rights (Peet \& Hartwick, 2009, p. 95). The policies were intended to be used as conditions for lending money to Third World countries. The International Financial Institutions (IFIs) applied neoliberal policies under the appellation of "structural adjustment reforms". 
Structural adjustment, then, describes a package of policies associated with loans to developing countries by the International Monetary Fund (IMF), the World Bank, donor governments, and regional financial institutions. It consists of policies and practices directed toward the control of inflation (stabilization), a reduction of government intervention in favor of the market (liberalization), and the privatization of the public sector institutions to "improve the technical efficiency of production" (Clark, 1991; Escobar, 1995; Goldin, 2016). Based on its conditions, a state adopting such reforms would be compelled to limit its involvement in national state-centered economic development, cease or reduce its regulatory intervention in the private sector, and considerably reduce social entitlements as well as healthcare and education expenditures (Degnbol-Martinussen \& Enberg-Pedersen, 2005; Dupuy, 2005; Goldin, 2016).

These structural adjustment policies have increased corporate profitability. Debt service payments on loans carrying high interest rates in the early 1980s helped to fuel several years of record earnings by international banks (Rahnema \& Bawtree, 1997). However, the social and economic costs of debt-servicing regimes on the third world population proved to be disastrous. The structural adjustment programs were accompanied by high unemployment rates, while fueling an increase in the cost of necessary goods and services. As Escobar points out, "the burden of Structural Adjustment policies, although affecting drastically the middle and popular classes as a whole, has fallen harder on the poor, especially the poor women," (Escobar, 1995, p.176). The repercussions were felt in the creation of conditions that led to Third World reliance on NGOs, and they completely modified the architecture of power and governance in countries pursuing neoliberal programs. 


\section{Neoliberal Policies, NGOs, and the Implications on the State}

During the 1990s, neoliberalism reached its zenith as markets became increasingly globalized. It came to be understood that growth and development could occur only through engagement with the globalized economy. Open markets, trade liberalization, and privatization of public goods and services transformed development into a private enterprise (McMichael, 2008), which promised the betterment of people's conditions (Hintzen, 2018). The post-World War II focus on national development to target improvement in conditions of national populations became overshadowed by this emphasis on participation in the globalized economy. This reality was particularly evident in the application of new policies by the United States and the International Financial Institutions. Development funding was diverted away from governments, and toward NGOs. Consequently, the 1990s saw a sevenfold increase in NGOs' official aid funding, from one billion dollars in 1970 to seven billion dollars in 1990 (Ahmed and Potter, 2006). As NGO funding began to increase significantly, so did their global presence. From around six thousand NGOs in 1990, their numbers increased to an estimated sixty thousand by 1998 (Reagan, 2003, p. 3). The shift in aid funding to NGOs increased their relevance and influence, and simultaneously weakened the governments of developing countries (Dupuy, 1997, 2005; Ferguson, 2006; Etienne, 1997; Schuller, 2009, 2012).

Various scholars have focused on different aspects of the shift to NGOs. Anthropologist Michel-Rolph Trouillot analyzed the displacement of state functions and practices, mainly to supra-governmental organizations and NGOs. He framed this as indicative of the emergence of a "fragmented globality that questions the effectiveness of the national state as primary site for economic exchange, political struggle, or cultural 
negotiation" (Trouillot, 2001 p.130). Similarly, James Ferguson pointed to the emergence of a "new sort of governance" in the wake of neoliberal policies that provoked a "rolling back" of the state. Consequently he writes, "at the same time, swarms of new nongovernmental organizations (NGOs), taking advantage of the shift in donor's policies that moved funding for projects away from mistrusted bureaucracies and into what were understood as more 'direct' or 'grassroots' channels of implementation," (Ferguson, 2006, p. 38). Referring specifically to the case of Africa, Ferguson argued that "the new sort of governance" was supposed to be "both more democratic and more economically efficient" (Ferguson, 2006, p. 38). However, this "rolling back of the state has provoked or exacerbated a far-reaching political crisis. As more and more of the functions of the state have been effectively 'outsourced' to NGOs, state capacity has deteriorated rapidly" (Ferguson, 2006, p.38). The state became nothing more than a "shadow state, "which transforms the formal institutions of government into little more than empty shells (Ferguson, 2006, p.39).

With this rolling back of the national state came an increase in poverty and scarcity in the global south. Famine in Sudan and Somalia killed millions of people in the 1990s. Across Ethiopia, Somalia, and Kenya, droughts and hunger swept away vast populations and livelihoods. And, faced with such disasters, populations in the global south relied increasingly more on NGOs for social services that once used to be provided by the state. In 2008, Riddell wrote:

The last 25 years have witnessed a phenomenal growth in the contribution of NGOs to the overall aid effort. NGOs run many times more development projects and programs than those funded by official aid agencies, and by 2004 , the total value of 
NGO-funded activities was almost $\$ 24$ billion, equivalent to over 30 percent of overseas development aid (ODA). In some countries, NGOs (including churchbased agencies) are responsible for 10 percent of health and education services - in a few countries, such as Haiti, probably in excess of 50 percent. In Bangladesh, one NGO on its own, the Bangladesh Rural Advancement Committee (BRAC), provides basic curative and preventive health services to more than 97 million people, out of a total population of 143 million (Riddell, 2008, p. 260).

\section{Neoliberalism: When the "Un-usable" Becomes "Usable"}

Ferguson (2006) demonstrated that with globalization, the Africa that was particularly ignored by the global capital has become transformed. He notes that global capital now identifies a "usable" and an "unusable" Africa. The "usable Africa" refers to African territories with an abundance of natural resources., while the "unusable Africa" constitutes the rest of the continent and its poor people. Ferguson finds that global capital hops over the "unusable" Africa and lands on the "usable Africa".

This argument of "usable" and "unusable" areas, while quite solid, does not always encompass the reality of neoliberalism in the global South, or even the reality of Africa. Aiwa Ong (2006) argues that neoliberalism operates as an exception. As such, neoliberalism has the capacity to transform and mutate markets and populations in ways that are beneficial to the capitalist economy. Ong demonstrates how, for example, a variety of neoliberal strategies has been developing and re-engineering political spaces and populations in the East and Southeast Asian states to the benefit of market capitalism. Hence, even in the "unusable" parts of the world, neoliberalism has the capacity to form 
engagements that allow the market to function and extract profits. This is made possible through forms of "exception," where global capital is granted exceptional authority and autonomy in areas of the country where people and resources are "excepted" from forms of state regulation. My argument is that neoliberalism creates conditions where non-usable populations are forced into global production and - to some extent - consumption.

Neoliberalism creates conditions where the state no longer caters to certain parts of the country and has instead abrogated its jurisdictional authority either to control by global capital or to depend on NGOs. In countries that heavily rely on NGOs, they tend to bridge the gap created by the withdrawal of the state (Schuller, 2009). They assume the functions of the government in catering to the needs of the population. Concurrently, populations often come to rely on their own economic initiatives. They do so by developing an informal economy or resorting to subsistence, accepting migration as segmented informal labor, and even growing illegal drugs within their territories.

The goal of neoliberalism is to reduce state control of global economic processes, and to create conditions for the insertion of its people and resources into these processes (Hintzen 2018; Ong, 1999; 2006; Robinson, 2014). Therefore, neoliberalism obliges usable labor to depend on the global economy and marginalizes non-usable labor because it does not have "effective demand." Once this occurs, the marginalized are constrained into the global economic circuits, which NGOs facilitate (Hintzen, 2018). This process does not undermine the fact that local populations continue to revert to subsistence production as an alternative (Hintzen, 2018). However, for the most part, non-usable labor and populations are forced into global production and - indirectly - global consumption. In the case of West Africa, for example, non-usable populations are forced into exploitable labor (mineral 
production of diamond, Coltan, etc.) in order to dramatically reduce production costs by forcing labor to engage in its own subsistence (Ferguson, 2006). NGOs facilitate this process by providing food, healthcare, and subsidized housing to those populations, which ensures sustainability and reproduction of the system without the need for transfers from the state or capital.

My argument so far is that in the global capitalist market, nothing is wasted, but all is transformed; "unusable" populations are transformed into "usable" populations through the services provided by NGOs. Indeed, if we look at NGOs from a market-driven perspective, we will understand that they facilitate a massive transfer of goods, expenditures, and technology to Third World populations. All equipment - the expensive SUVs, supplies, generators, etc. - that NGOs use to reach these remote areas, set up offices, and conduct daily operations are primarily supplied by Northern countries. In this way, NGOs represent a very important conduit between the global capitalism market and the Third Word.

Because of NGOs, the "unusable" populations of the Third World have access to global consumer goods that otherwise would not be possible. One may argue that the transfer of goods and technology to the Third World is not the primary function of NGOs. They only indirectly serve this purpose, a fact that I do not overlook in my research.

In the age of globalization, flexibility remains one of the main characteristics of market capitalism. In The Condition of Postmodernity (1989), David Harvey identifies late capitalism as a "regime of flexible accumulation." In terms of capital, flexibility refers to the ability to move capital both in terms of production location and financial assets as well as the production of different goods and services. In terms of labor, flexibility refers to the 
ability to migrate and do different types of jobs. In short, capital moves around the world, as do people. We have witnessed that more people are traveling internationally for better jobs and greater access to economic gains. Ong particularly places this flexibility in a cultural logic of the global capitalism system. As she puts it:

In their quest to accumulate capital and social prestige in the global arena, subjects emphasize, and are regulated by, practices favoring flexibility, mobility, and repositioning in relation to the markets, governments, and cultural regimes. These logics and practices are produced within particular structures of meaning about family, gender, nationality, class mobility, and social power (Ong, 1999, p.6).

The practice of "flexibility, mobility, and repositioning" (Ong, 1999) is on the rise in the Third World due to the presence of NGOs. In the countries where northern NGOs operate on a large-scale, such as in Haiti and Kenya, one can notice not only a movement of capital, goods, and technology but also of people and technocrats. These people move because, even as NGO workers, they are central actors in the global economy. Indeed, most of the NGOs' directors and high-ranking personnel come from Western countries. Thus, they are critical to the maintenance of global capitalism by reducing the need for transfer of revenues from profit into welfare, hence contributing to super profits and low taxes. In the case of Haiti, particularly after the 2010 earthquake, NGO presence - in addition to other bilateral and multilateral agencies - have led to an escalation in the number of expatriates in the country (Hintzen, 2019) who saw in post-earthquake rehabilitation an opportunity for economic gain, but also for prestige and power.

My research on NGOs in Haiti following the 2010 earthquake began with an observation of the transnational flow of people and money. Later, my focus shifted to 
investigating both the effectiveness and limitations of NGOs to deliver disaster relief in a way that can produce sustainable development outcomes based on the study of Haiti. NGOs are critical to neoliberal transnational capital. They also contribute to economic leakage and limit backward and forward linkages, since their wages are either earned in or returned to their home countries or used for foreign breakdown.

\section{Haiti: Post-Revolutionary History and Underdevelopment}

Haiti is often referred as the poorest country in the Western hemisphere. It is important before we go further to uncover the roots of its underdevelopment, which is the main condition of the country's vulnerability to disasters.

\section{Background}

Port-au-Prince has a long history of naturally catalyzed disasters that began during the colonial period. In 1751, two years after it was founded, two cyclones and two earthquakes hit Port-au-Prince. These events destroyed most of the city's buildings. In November of 1770, the city was hit by one of the strongest earthquakes in the island's history. The earthquake produced a tsunami that leveled the capital, causing two hundred deaths. Scherer J. (1912), in Great Earthquakes in the Island of Haiti, attributes the relatively low death toll to a rumbling sound that preceded the quake, which allowed people enough time to flee their houses before the shaking started. The earthquake struck twice within four 
minutes. In its wake, an ordinance was passed to ban construction forms deemed vulnerable to natural disasters (Joseph, 2008; O’Loughlin, Karen F. \& Lander, James, F., 2003).

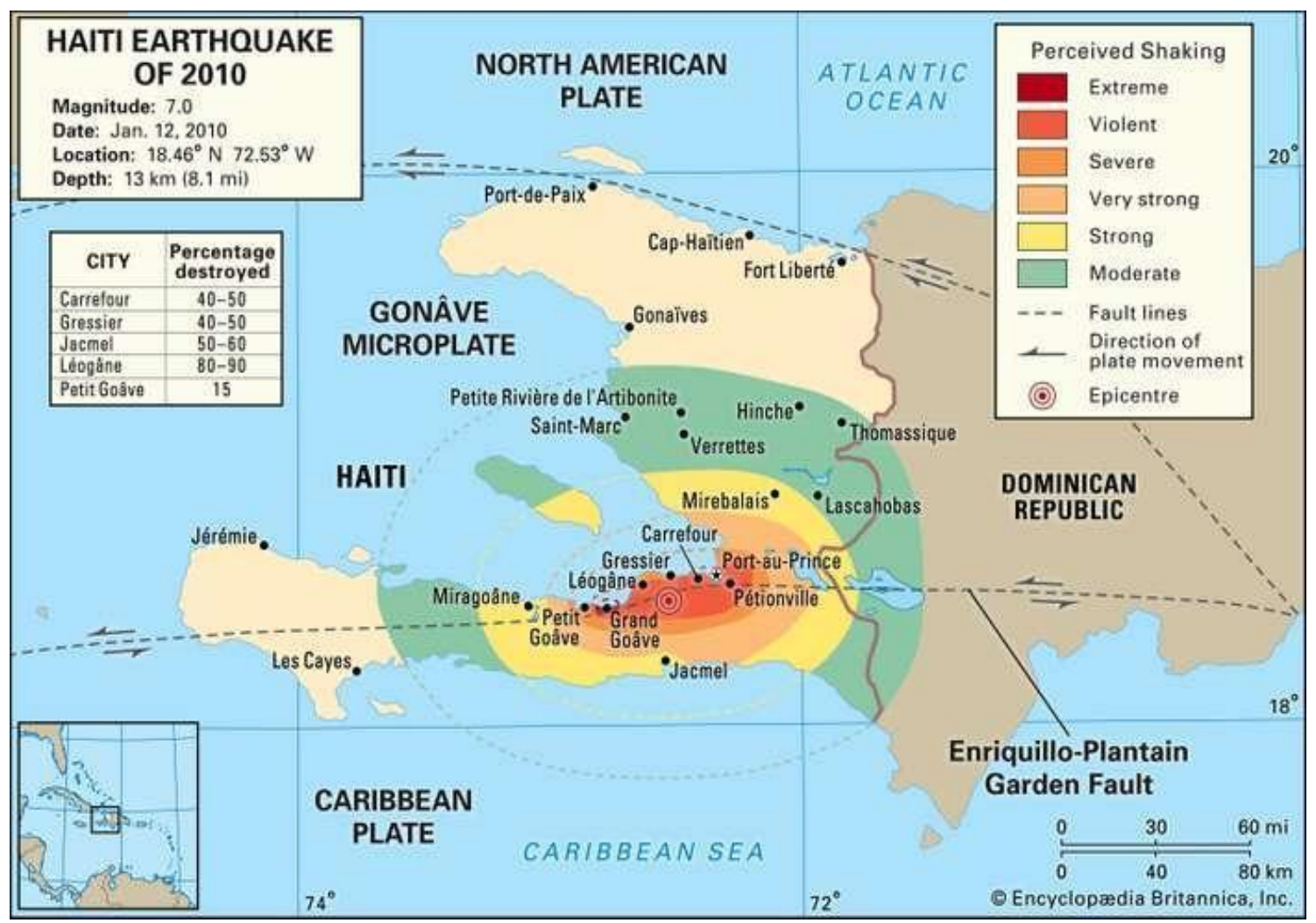

Figure 1.2: Map Haiti depicting the intensity of shaking and degree of damage incurred by the January 12, 2010 earthquake. Source: Encyclopedia Britannica, Inc.

Throughout the 19th and the 20th centuries, different forms of catastrophes have hit Port-au-Prince, many of which have caused severe damage and human casualties. In addition to earthquakes, the most common are cyclones, tropical storms, and floods. However, over the last 30 years, Port-au-Prince's vulnerability to natural disaster has seemed to increase. For example, the low death toll in 1770 was attributed to a public understanding of tsunami warning signs, and also perhaps a low population density combined with the way homes were constructed. It also seems that the government was in 
a position to implement effective measures, such as the ordinance for construction of lowrisk homes. This is no longer the case. To understand Port-au-Prince's current high vulnerability to natural hazards, we first need to situate the city within a larger context of a country with a past that is inextricably entangled with external hostilities, organized international racial conspiracy, and long-lasting political instability. Secondly, we must analyze the local factors that contribute to Port-au-Prince's vulnerability, particularly internal migration and unplanned growth.

International Factor: The Legacy of The Past

After Haiti's independence in 1804, which created the first Black independent nation in the Western hemisphere, the country was politically and economically isolated. In the year following the Haitian revolution, France - with the help of the U.S. and allied European powers - orchestrated a diplomatic quarantine of the new Black Republic (Farmer, 2006). In fact, the country's independence produced such a fear of revolutionary contagion that white colonizers in Europe and the U.S. felt compelled to take action to avoid potential replication. As a result, Haiti was ostracized and isolated for most of the 19th century, which had serious and long-lasting economic consequences for the young nation.

This isolation was imposed on Haiti by frightened white world, and Haiti became a test case, first, for those arguing about emancipation and then, after the end of slavery, for those arguing about the capacity of blacks for self-government. Great Britain was one of the few nations that had diplomatic relations with Haiti, and it was from the writings of English racists and abolitionists that Haiti began to garner widespread bad press (Lawless, 1992, p. 56). 
In addition to the international racial conspiracy against Haiti, in 1825 France imposed a heavy indemnity on the country. This was to compensate for the financial loss French colonizers and slaves' owners had suffered during the Revolution. Afraid of an eventual French power grab, the Haitian government agreed to pay this indemnity. It took Haiti almost the entire 19th century to pay the 'independence debt,' which consequently led to the country's bankruptcy. However, it would be disingenuous to attribute Haiti's overall vulnerability to natural disasters to international causes since national factors, combined with local factors in Port-au-Prince, played critical roles in the 2010 earthquake.

\section{Internal Conflicts and Underdevelopment}

Internal conflicts are also quite responsible for Haiti's failure. The Haitian Revolution was made possible through an alliance between Blacks and Mulattoes. This alliance was inherently fragile, since the mulattoes also had a vested interest in maintaining slavery. Once they succeeded in their Revolution, the two factions began to fight over control of the new country. The question of the color line has thus, for centuries, augmented deepseated divisions and class struggles in the country. Moreover, Haiti, as the first Black independent country, had no prior example to build on. Organizing a people accustomed to slavery was a challenging task for the country's first leaders. As a result of these internal factors, more than two hundred years after the Revolution, Haiti continues to struggle with the after-effects of slavery and colonization.

Deep-seated social divisions and political instability have undermined the country's capacity to build a nation. If a nation is perceived as an 'imagined community' - a sociallyconstructed community imagined by people that view themselves as part of the same group 
despite their differences (Ferguson, 1983) - then Haiti, as a nation, was never fully “imagined." Rather, Haiti is a state that operates under a mechanism where political power is a means to gain wealth, and the state serves the egoistic interests of few. The country's fundamental problem is that the state is against the nation.

While I will analyze this premise at length in chapter five, I must remark here that Haiti has been continually ranked among the most corrupt countries in the world by the International Corruption Index. Successive World Bank reports have attributed the causes of underdevelopment in Haiti to poor governance, political instability, long-lasting corruption, and the misuse of public funds (Dupuy, 1996; 2005). Particularly, in 1996 the Bank's report said:

Haiti has never had a tradition of governance aimed at providing services to the population or creating an environment conducive to sustainable growth. Instead, a small elite has supported a 'predatory state' that makes only negligible investments in human resources and basic infrastructure (World Bank, 2002, p. 3).

The economic elite in Haiti is composed of a few families who have dominated the country's economy for the last fifty years. With the complicity of the state, and through phony contracts, they control the ports and other important segments of the economy. This has resulted in the monopoly of key industries, distorted competition, and twisted business practices (Singh \& Barton-Dock, 2015). Basic needs and "most important food products in the Haitian consumption basket are sold in concentrated markets, and a preliminary analysis indicates that the prices of these products are on average about 30-60 percent higher in Haiti than in other countries from the region" (Singh \& Barton-Dock, 2015, p. 2). 
The elite's economic control is entangled in the control of the state. They bribe political leaders and government officials. In return, they receive economic advantages, lucrative government contracts, preferential treatment, and access to diverse financial and economic benefits. This quid pro quo culture is so prevalent in Haiti that the provision of government jobs has become one of the most lucrative endeavors in the country. A high position in government is the quickest and easiest way to gain access to the wealthy, and to get rich through selling services and squandering public funds. An old Haitian proverb says, "stealing from the state is not stealing." As a result, the country produces more millionaires per capita than any other in the Western hemisphere (Pierre Louis, 2011). As a minority of the population is getting rich through political corruption and non-transparent business practices, the vast majority lives in deplorable conditions.

In the years preceding the 2010 earthquake, 76 percent of the population (more than 4.4 million people) were living on less than two USD per day, and 56 percent fell below the extreme poverty line of less than one dollar per day. Eighty percent of the population earned only 32 percent of the country's income. Only thirty percent of public healthcare services were provided by the government, and 72 percent of the population barely had access to healthcare (International Crisis Group, 2009). Less than two years before the disastrous earthquake, in August and September of 2008, four tropical storms and hurricanes hit the country. Eight hundred people were killed and nearly one million affected, with extensive damage to the infrastructure and agriculture. This, in turn, exacerbated food shortages, increased the cost of living, and caused widespread disruption and suffering (International Crisis Group, 2009). 


\section{The Case of Port-au-Prince: Population Density and Unplanned Growth}

Compared to Port-au-Prince, rural areas were neglected, and thus economic and social conditions were even more dire in these areas. Migration to urban spaces, particularly Portau-Prince, constituted the only way out for abandoned peasants; 13,000 people from rural areas migrated annually to Port-au-Prince, swelling the city's slums (World Bank, 1998). In 1982, the population in Port-au-Prince was estimated to be 720,000 (World Bank, 1998); this reached 2.3 million in 2009 , which represented a density of 65,000 people per square mile (World Population, 2020).

With the massive migration to Port-au-Prince, the quality of urban life has significantly deteriorated. As the World Bank states, "the rapid and unplanned growth of the low-income population in urban areas has created high-density settlements and exerted extreme pressure on the scarce basic services and limited infrastructure of the cities" (World Bank, 1998, p. 9). Road conditions worsened, and the already-limited drainage canals filled with waste and garbage, which increased the occurrence of floods. In addition, construction in unsafe zones became normal. With a state that enforces no building codes or public safety laws, people have built unsafe structures and now live in unsanitary, overcrowded, and dangerous conditions. Such conditions render Port-au-Prince extremely vulnerable to catastrophic natural disasters, and this explains the massive damages resulting from the January 2010 earthquake. 


\section{Chapter Summaries}

My dissertation is divided into seven chapters. In Chapter two I briefly theorize the issue of climate change and the rise of natural disasters since the 1960s. Then, I address the changing relationship between disaster aid and development. To illustrate this changing relationship, I analyze the historical evolution of disaster, as a concept, since the 1950s. I demonstrate how a change of thinking in disaster studies during the 1980s and 1990s has brought the concept of development into the disaster discourse. I also critically examine disaster aid. I unpack the humanitarian, moral, political, and economic arguments that underpin disaster aid. I conclude the chapter with the Hyogo Conference on Disaster Reduction's call for disaster aid to be delivered and implemented in ways that can promote development and reduce vulnerability to future disasters. The remainder of the chapter focuses particularly on development. I survey three developmental approaches. I analyze Amartya Sen's approach that equates development to freedom. I examine Hintzen's approach, which is both a continuity and a critique of Sen's approach. While Hintzen shares the idea of development as freedom, he poses the systematic conditions for that freedom to flourish, which is possible only under the conditions of democracy and good governance. I also examine Anderson and Woodrow's approach, which views development as the process by which capacities are increased, and vulnerabilities decreased.

Chapter three critically examines the political and economic factors that led to Haiti's reliance on NGOs. This chapter is fundamental to my research, as it investigates how neoliberalism destroyed the Haitian economy and created a heavy reliance on NGOs. I argue in this chapter that neoliberalism has been implemented in Haiti in two phases: The 
first phase corresponds to the beginning of the implementation during the 1980s, the second articulates a full implementation of neoliberal policies in Haiti.

Chapter four analyzes the political, economic, and demographic conditions of the country before the 2010 earthquake. I use Trouillot's framework of the 'state against the nation' to make sense of the case of Haiti. Trouillot has demonstrated that, under the Duvalier regime, the state was used as an instrument against the nation. While Trouillot's framework was initially applied in the context of Duvalier's regime, I argue in this chapter that in the post-Duvalier era, the state continues to be used as a weapon against the nation.

Chapter five focuses on relief intervention efforts in the wake of the 2010 earthquake. I emphasize the language used in an International Donors' Conference around terms such as "build back better, recovery and rebuilding," and "new Haiti. I explore an action plan under the direction of the Haitian government to point out the divergences between the language used and what was put into practice. In this chapter, I also present and analyze the results of the survey conducted to determine the perceived effectiveness of NGO intervention. I measure this against objectives presented in an International Donors' Conference held in New York and the action plan developed under the direction of the Haitian government.

Chapter six examines the failure of the post-disaster intervention to address existing vulnerabilities and realize development transformation. As evidence of this failure, I highlight the fact that even the major government buildings are still not yet rebuilt, ten years after the earthquake. I also demonstrate that this failure exacerbated existing vulnerabilities and created new ones. As an alternative, I argue for an effective collaboration with NGOs and local government and organizations. 
In Chapter Seven, I argue for a need to link relief, rehabilitation, and reconstruction. I demonstrate that in order for a post-disaster intervention to realize development transformation and produce resilience to disaster, rehabilitation and reconstruction need to occur simultaneously. I concluded the chapter with a positive note by highlighting the case of two NGO projects that demonstrate good practices toward building resilient communities. 


\section{Chapter Two: Disasters Relief, NGOs, and Development: A Scholarly Focus}

My research is located at the intersection of three broad bodies of scholarly focus: disaster aid/relief, NGOs, and development. Before critically analyzing these three approaches, it is important to note that the literature on disaster research has - until now - been fragmented among disciplinary and analytic frameworks. While sociologists tend to focus on organizational behavior during disasters, geographers posit the problem of place, and political scientists address risk assessment policies and practices. However, my research draws on the political economy perspective that has dominated the discourse on disasters since the 1980s. By specifically analyzing natural disasters in the Third World, this perspective identifies the root causes of disasters as they relate more to social and economic conditions than to natural phenomena (Blaikie, 1994; Blaikie et al. 1994; Cannon, 1994; Handyman \& Handyman; Hewitt, 1983; 1997; Hilhorst, 2004; Hilhorst \& Bankoff, 2004; 2006; Lavell, 1994; Oliver-Smith, 2003). Through this perspective, disasters are understood as a product of social processes that create unequal exposure to hazard and risk, leaving some people more vulnerable to disasters than others (Hilhorts \& Bankoff, 2004). Poverty, social exclusion, chronic malnutrition, and lack of effective development constitute some of the primary roots of disasters (Blaikie et al. 1994; Hewitt, 1997). The fact that those conditions are more present in developing countries explains the frequency of disasters in such areas (Hilhorst, 2004; Ward \& Shively, 2017).

Building on that premise, the main argument of my research is that, to build disaster resilience in developing countries, disaster relief/aid must make development a centerpiece of its intervention in order to reduce vulnerability in the future, and to be delivered in a manner that furthers this goal. 


\section{Disaster Relief: Context and Evolution}

The concept of 'disaster' refers to a "serious disruption of the functioning of a community or a society causing widespread human, material, economic or environmental losses which exceed the ability of the affected community or society to cope using its own resources," (UN, 2004; p. 17). In the wake of a disaster, we often witness an outpouring of assistance given to the people affected. This assistance is generally referred to as "humanitarian aid," "emergency relief," "disaster aid," or simply "relief." The agencies providing aid are commonly known as "humanitarian agencies." Among these, the United Nation agencies and NGOs are the largest and most visible (Riddell, 2007). Thus, grappling with how best to deliver disaster relief requires first that we address the problem of disasters.

\section{Living Dangerously: Climate Change and the Rise of Natural Disasters}

We are living in a time of deep uncertainty, largely due to climate change. Climate change, particularly as it causes rising temperatures and changing rainfall patterns, will affect human livelihood over the next century, and increase both the frequency and magnitude of weather-related hazards (Schipper \& Pelling, 2006). The United Nations Intergovernmental Panel on Climate Change (IPCC) reports that since the late nineteenth century, the average global surface temperature has increased by 0.6 degrees centigrade. It is projected that the average surface air temperature will increase between 1.4 and 5.8 degrees centigrade by 2100 . It is also projected that average global sea levels will rise between 0.09 meters to 0.88 meters by 2100 (Dore and Etkin, 2003). While it is difficult to foresee what impacts these changes will have, it is certain that climate change represents 
a threat to the environment and to humanity, as evidenced by the increasing frequency of natural disasters. We are, therefore, living dangerously (Reid, 2014). Whether in the United States, China, Europe or the Caribbean, increasing numbers of lives are lost every year as a result of catastrophic climate extremes.

However, it is widely recognized that the impacts of climate change have had dramatically disparate levels of destruction in different places. The Johannesburg Declaration on Sustainable Development notes that "the adverse effects of climate change are already evident, natural disasters are more frequent and more devastating, and developing countries more vulnerable." Whether analyzing disaster frequency in developed or developing countries, it is important to situate the debate within the context of economic development.

\section{The Changing Relationship Between Disaster and Development}

Academically and practically, the relationship between disaster and development has been shifting over the recent decades. In this section, I will illustrate how the two have been linked, especially since the 1960s.

\section{The Dark Decades (1960s-70s)}

I call the 1960 s and 70 s the dark decades. It was a period when no valuable work to link disaster and development was attempted. Disasters were seen as neither related to nor exacerbated by underdevelopment. Instead, disasters were attributed to the environment and nature (Bolt, 1978). They were viewed as a consequence of "extremes in geophysical 
processes" (Hewitt, 1983, p.4). Because disasters were attributed to the environment and nature, they were treated as something outside of society (Hewitt, 1983). In this regard, Hewitt writes:

The geography of disaster is an archipelago of isolated misfortunes. Each is seen as localized disorganization of space, projected upon the extensive map of human geography in a more or less random way due to independent events in the geographical realms of atmosphere, hydrosphere, and lithosphere. More specifically, each disaster is an unplanned hole or rupture in the fabric of productive and orderly human relations with habitat or 'natural resources,' (Hewitt, 1945, p. 13).

In this environmentally deterministic view, terms such as "misfortune," "act of God" (Fisher, III, 1998), "unusual events" (Toblin, 1977), and "accidents" (Haddon, Suchman, \& Klein, 1964) were used to explain disasters. By describing disaster in this way, the environmental determinists created a discourse that reduced disasters to unmanaged, unexpected, and unprecedented phenomena. This discourse did not allow for the possibility that humans might preemptively mitigate the impact of disasters. The approach of environmental determinism led researchers, naturally, to focus on appropriate reactions to disasters and effective emergency measures after the disaster has occurred. Consequently, researchers and scholars failed to focus on factors that produced disasters, but instead on disaster response. 


\section{Emergence of Disaster Behavior and Crisis Management (1970s)}

During the 1970s, social scientists focused on the socioeconomic and behavioral impacts of disasters. They formulated what came to be known as the behavioral school. They began to look at how people and institutions respond to disasters. A key figure of this period was Enric H. Quarantelli, the founder of the Disaster Research Center, the first social research center on disaster in the United States (Fisher III, 1998). Other scholars, such as Thomas E. Drabek and Russell R. Dynes, were also part of the behavioral school on disasters. These scholars explored disaster as a social problem. Their focus was on the behavior of individuals and organizations toward mitigating damage, and their responses to actual disasters and potential threats posed by their occurrence (Fisher III, 1998).

Sociologists brought new insights to disaster studies during the decade of the 1970s. Nevertheless, Kenneth Hewitt, a neo-Marxist political geographer, found that the sociological approach reinforced what he called the "geophysicalist dominant view" of disasters (Hewitt 1983). Hewitt criticized the sociologists' argument that simply indicated that a greater number of people are vulnerable to natural disasters mostly because they are located in dangerous areas (Hoffman and Oliver-Smith, 2002). Hewitt critiqued disaster sociologists such as Enrico Quarantelli and Russell Dynes for voicing the need for disaster research. He also emphasized human behaviors to address the pre-existing conditions such as overpopulation, risk areas, and accidental features of places and societies. Hewitt called those efforts "window dressing, dealing with issues that do not penetrate beyond conceptual preambles," (Hewitt, p. 16 1983). He argued that the dominant view placed disaster outside the structural order and contemporary social developments that pervade 
everyday life and cause disasters in the first place (Hewitt, 1983, p. 25). Hewitt called for a break with the past.

\section{Paradigm Shift in Disaster Studies (1980s-90s)}

The publication of Interpretations of Calamity in 1983, edited by Kenneth Hewitt, led to a shift in the approach to disasters. In a critique of the then dominant approach to disasters that he believed was insensitive to human development and social inequalities, Hewitt wrote in the introduction to the volume:

The dominant view then belongs to a historically special culture that seeks to interpret the world through its underpinnings in material phenomena and mechanism. Disaster remains a difficult, perhaps a decisive, test of such explanations. It is a deliberate problem for prevailing interpretations of nature and human development and the way they are appropriated by technical institutions Disaster, taken literally, however, suggests revolutionary change (p.18).

Thus, Hewitt called for a fundamental change - what scholars such as Thomas Kuhn (1962) called a "paradigm shift" - in the way we thought about and understood disasters. Of the factors that contributed to Hewitt's decision to call for a shift in disaster research, we can consider two in particular:

1) Since the $1960 \mathrm{~s}$, there has been a considerable increase in natural disasters (Pelling, 2003; Janse and Flier, 2014; Grove, 2010). This increase proportionally affects developing countries, which underscores a relationship between disaster and underdevelopment. Indeed, Pelling (2002, 2003) reports that the number of natural disasters reported per annum has doubled since the 1960s. During the 1980s and 90s, 
scholars have observed a disproportionate occurrence of disasters in developing countries. For example, it was observed that during the 1990s, 96 percent of the annual average number of persons killed and 99 percent of people affected by hazards resided outside the United States, Canada, and Europe (Walker and Walter, 2000, pp.173-175). This disproportionate occurrence underlines the argument that disasters were not merely a consequence of geographic position, but rather of demographic and economic differences, thus highlighting the fact that inhabitants of developing countries are more likely to die from disasters (Bankoff, 2004).

2) We must also consider the uneven impacts of disaster: As disasters increase in the developing world, the most vulnerable are the most affected. Following the 1976 earthquake in Guatemala, Marxist disaster scholars began to take a closer look at the relationship between social and economic conditions as related to disasters, as it was evident that low income and indigenous people were struck harder by the earthquake (Blaikie, 1994; Wisner, 2003). More and more disaster scholars began to study disaster through a political-economic lens. It became clear that social power and material conditions had a profound effect on the social distribution of risk (Blaikie, 1994; Wisner 1993; 1996, 1998). Indeed, numerous disasters occurred mostly as a result of inequality, population displacement, and other material conditions that particularly affected the poor. Ben Wisner cites many examples that support this argument. Among them is the case of Hurricane Mitchell, which killed 30,000 people in Honduras and Nicaragua in 1998 (Wisner, 2003). He argues that the impact of the hurricane is a consequence of the displacement of the population by agri-businesses, which forced them to live in unsafe conditions. 
Considering the structural factors that shape the social and economic distribution of risk, Terry Cannon made an important and critical distinction between hazards and disasters. He argued that while hazards are natural phenomena, disasters are not. Instead, disasters are symptomatic of social processes that generate unequal exposure to risk, which make some people more vulnerable than others (Cannon, 1994, p. 14-19). By analyzing disasters through the lens of vulnerability, we can also gain insight into the relationship between disaster and development. The African NGO Periferi defines vulnerability as a "set of prevailing or consequential conditions composed of physical, socio-economic, and/or political factors that adversely affect the ability to respond to events," (Holloway, quoted in Delica-Willison \& Willison, 2003, p.148). Those factors impact the social and economic conditions in underdeveloped communities. Blaikie et al. strengthened this argument by pointing out that "vulnerability is deeply rooted, and fundamental solutions involve political change, radical reform of the international economic system, and the development of public policy to protect rather than exploit people and nature" (Blaikie et al., 1994, p. 233).

\section{Disaster, Climate Change, and Development: A Global Concern}

The 21 st century began with increased global concerns about climate change as the number of disasters and related economic losses continue to increase. For example, between 1990 and 1999, there were a total of 82 major disasters. The resulting economic losses totaled 535 billion USD (UN, 2004, p. 45). This shows that climate-related natural hazards have the potential to hinder or even reverse years of development gains and make development goals even more difficult to achieve in underdeveloped areas (Dilley et al. 2005; Grove, 
2010; Schipper \& Pelling, 2006). Considering the scope of danger that climate change may represent to development, the $\mathrm{UN}$ has adopted several resolutions intended to address the connection between disaster and development.

One example is The UN Millennium Development Goals, adopted in 2000, which recommended that national governments incorporate disaster risk reductions into national development policies. The 2005 Hyogo Framework for Action argued that a priority for action should be to use "knowledge, innovation, and education to build a culture of safety and resilience at all levels." The 2015 Sendai for Disaster Risk Reduction also placed resilience at the center of disaster risk reduction. These are based on the idea that resilience is "the capacity of a system, community or society potentially exposed to hazards to adapt, by resisting or changing in order to reach and maintain an acceptable level of functioning and structure," (UN 2004 p. 16). What I argue in this research is that an effective delivery of disaster aid must take into account a development strategy that fosters a culture of resilience as a necessary condition, which I will discuss later in this chapter.

\section{Disaster Aid}

According to Roger Riddell, disaster aid is "aid provided to help those whose lives are profoundly affected by, and whose livelihoods are immediately at risk as a result of natural or man-made disasters," (Riddell, 2007, p. 311). Natural disasters include earthquakes, floods, hurricanes, tsunamis, droughts, famines, and the like, while man-made disasters mostly refer to victims of wars and other situations of severe political, economic, and social breakdowns. The aid provided to help people affected by disasters (natural or man-made) is often referred to as humanitarian aid or assistance, relief, or emergency relief. Disaster 
aid is largely provided by four main agencies: government official donors such as the United States, multilateral agencies, humanitarian agencies such as United Nations agencies, and NGOs. The purpose of humanitarian aid is to save lives, alleviate suffering, and enable people who are suffering to maintain their dignity during and after a disaster (OECD, 2004a).

The literature on disaster aid has paid a great deal of attention to natural disasters due to the fact that natural disasters have increased since the 1960s, as explained earlier (O'Byrne, 2013; Schipper \& Pelling, 2006; Riddell, 2007). Riddell stresses that "the total number of [annual] disasters reported since the mid-1950s rose from fewer than 80 in the mid-1960s to more than 200 by the end of the 1970 s. This number rose further to 300 , by the start of the 1990 s, to over 700 by the turn of the century, and to almost 850 by 2005 ," (Riddell, 2007). Just as the number of disasters has risen, the damages and loss of human lives resulting from such disasters are also skyrocketing.

It has been demonstrated that damage is often unevenly distributed, specifically as it relates to the loss of human lives. Disaster mortality is far greater in poor countries. O'Byrne (2013), in his article Dealing with Disasters in an Age of Globalized Sentiment: Testing the Boundaries of the Cosmopolitan Ideal? offers an informative list of natural disasters that have occurred in recent years, along with the damages they have caused. This list includes the earthquake that ravaged part of New Zealand in February 2011 and killed 181 people. In Haiti, a massive earthquake in January 2010 took the lives of approximately 230,000 and severely destroyed the capital city of Port-au Prince. On February 27, 2010, an earthquake killed around 500 people in Chile and caused 3,000 casualties. In Afghanistan, 172 people were killed in February of the same year as a result of 36 
avalanches. Wildfires killed about 56,000 people in Russia in 2010, preceded by another 173 wildfire-related deaths in 2009. In China, 69,000 people were killed as a result of an earthquake in 2009, and 146,000 people lost their lives in Burma during the same year. In the United States, Hurricane Katrina took the lives of 1,836 people in 2005.

This list is far from exhaustive, but it nevertheless demonstrates the consistency of disasters, their potential for immense destruction, and where the human casualties often occur. Furthermore, the United Nations Development Program (UNDP, 2004) reports that only eleven percent of the people exposed to droughts, windstorms, floods, and earthquakes live in low-income countries. Nevertheless, those countries represent 53 percent of people who lost their lives as a result of those types of natural disasters. The World Bank (2004) also notes that when taking account of damages in terms of gross domestic products (GDP), poor countries' economic losses far exceed those of rich countries. As the number of disasters and level of damages rise, the international community has responded to correspondingly increasing appeals for disaster aid. Complete data is not available to assess the degree to which the international community has responded to disaster in the developing countries. However, it is estimated that in 2004, the total humanitarian aid amounted to 12.4 billion USD. When including private donations, the amount is estimated to have reached 15 billion USD (Riddell, 2007). Anderson and Lee reported (2015) that Indonesia alone received 7.7 billion USD over a four-year period in the wake of the 2004 Tsunami. This leads us to ask: What is the logic behind funneling so much money to disaster aid?

There is a problem in the rationale behind the allocation of disaster aid. A moral argument is often evoked to justify humanitarian assistance (Degnbol-Martinussen and 
Engberg-Pedersen, 2003). Based on this moral argument, a person who is well-off has an obligation to help those who are suffering and have poor access to resources. O'Byrne (2013) locates his moral argument within the framework of the 'cosmopolitan ideal.' This is derived from the capitalist ethic and linked to a form of cultural capital that makes the citizens of the West reflect on their global responsibility. It is made possible by the global media, which has transformed tragedies into global events (O'Byrne, 2013). However, this moral argument fails to recognize that most humanitarian aid is institutional (bilateral, multilateral, and NGO-based - even though the latter may depend on private personal contributions). In addition, I believe that individual responsibility cannot solve problems that demand institutional responses.

Disaster aid is the result of a much more complex reality. Degnbol-Martinussen and Engberg-Pedersen (2003) show that donors are often motivated by self-interest, as they argue that assistance to poor countries will benefit rich countries in the long-term. Aid, then, is built into the structural order that produces underdevelopment in the first place and contributes to the factors that cause disasters because it feeds donors' interests. My argument so far is that the way aid is given and allocated prevents its efficacy. Therefore, disaster aid needs to be allocated in new ways that can address the structural realities that produce disasters.

In addition to addressing structural problems that produce disasters, humanitarian aid needs to be given in an impartial and respectful way. Riddell, in his book: Does Foreign Aid Really Help? (Riddell, 2007, p. 312), stresses four principles that must guide the allocation of humanitarian aid, and that underscore the idea of respect and impartiality: 
1. The principle of impartiality: According to this principle, humanitarian aid should be provided solely on the basis of need, and thus without discrimination on the grounds of race, religion, gender, age, nationality, ethnicity, or political affiliation.

2. The principle of neutrality: Assistance is channeled to all civilians in need, and not to favor one side or the other in a conflict or a war.

3. The principle of independence: To ensure the neutrality of aid, it is broadly accepted that aid should be provided independently.

4. The principle of unconditionality: It is universally accepted that aid provided on the basis of need requires nothing back from the population to whom the assistance is being provided.

Such an argument about allocating aid in ways that can address social and economic causes of disaster is not necessarily new. Particularly, the 2005 Hyogo Conference on Disaster Risk Reduction called for disaster aid to be delivered and implemented in ways that could promote development, reduce vulnerability, and increase resilience to future disasters. This begs the question as to what form of development can produce resilience. If development policy produces disaster and prevents resilience, then how can these policies be reformulated? Before addressing those questions, let's briefly talk about NGOs.

\section{NGOs, Classification, and Potential Contribution to Development}

NGOs are "private organizations that pursue activities to relieve suffering, promote the interest of the poor, protect the environment, provide basic social services, or undertake community development," (World Bank, 1995, p.7). Scholars have attempted to classify them into several categories according to their work. In this paper, I use the work of Ahmed 
and Potter (2006), who categorize NGOs according to their role in international politics. These two scholars group them according to three roles: political, relief, and social and economic (p.37).

\section{Political Roles}

Many NGOs aim to challenge the political, social, and economic structures that breed poverty and inequality. Although NGOs are generally known as nonpolitical organizations, Ahmed and Potter (2006) report that many NGOs, both Northern and Southern, have begun to define themselves by their political, rather than economic, objectives. They engage in advocacy, lobbying, and agenda-setting activities.

\section{Advocacy and Lobbying}

The NGOs that engage in advocacy and lobbying are, according to Keck and Sikkink, those that "plead the cause of others or defend a cause or proposition. Advocacy captures what is unique about these transnational networks: they are organized to promote causes, principled ideas, and norms, and they often involve individuals advocating policy changes that can easily link to a rationalist understanding of their interests," (Keck and Sikkink, 2008, p.9).

Agenda-Setting

This category describes NGOs that address specific social issues, such as women's equality, environmentalism, or indigenous rights, and that put these issues on the political 
agenda. Many social ills have been addressed because of the work of NGOs. For example, women's rights and environmental protection have been on political agendas primarily because of the work of NGOs. Greenpeace and Consumer International are both examples of agenda-setting organizations.

\section{Relief}

According to Ahmed and Potter (2006), NGOs' role for most of the 20th century was that of charity and relief. This trend started with Christian missionary organizations that strove to address both spiritual and material poverty. Degnbol-Marinussen and Engberg-Pedersen (2005), in tracing the origin of NGOs, argue that most grew out of relief activities. For example, Red Cross, Red Crescent, Médecins sans Frontières (Doctors without Borders), and Oxfam were all born out of relief efforts. Oxfam, one of the most widely known NGOs, was originally created with the purpose of providing relief to wartime Greece. Many of these organizations later became development oriented.

\section{Social and Economic Development}

The involvement of NGOs in development has emerged from the reality that relief and charity work address short-term needs rather than long-term development problems (Ahmed \& Potter; Anderson \& Woodrow, 1989; Degnbol-Marinussen and EngbergPedersen, 2005; Pelling, 2004; Sirleaf, E. J., 1993). Another essential element that explains this involvement is the mandate of the U.S. Congress to use U.S. bilateral aid in a way that focuses more on the needs of the very poor in developing countries. In 1973, the United 
States Congress declared that foreign aid was to "be carried out to the maximum extent possible by the private sector, particularly those institutions which already have ties in the developing areas, such as educational institutions, cooperatives, credit unions, and voluntary agencies," (Ahmed and Potter, p. 41). Oxfam, CARE, World Vision, and ECHO are all in the development category; they focus increasingly on integrated services, microfinance, capacity-building, entrepreneurship, health, and other development projects (Degnbol-Marinussen and Engberg-Pedersen, 2005; Riddell, 2007; Smillie, 1997).

Other scholars have used other categories to distinguish NGOs, such as northern and southern NGOs, international NGOs (INGOs), transnational NGOs, and local NGOs. The latter refers to small national NGOs that receive funding from larger northern NGOs.

Until 1980, there was a clear separation between humanitarian assistance and development. Development programs were mostly carried out by the World Bank, the UN Development Program (UNDP), FAO, WHO, bilateral donors, and other developmentfocused organizations (Degnbol-Martinyssen and Engberg-Pedersen, 2003). By the end of the 1980s, some NGOs began to shift their focus toward development as a way to soften the adverse consequences of structural adjustment programs. This shift in NGO focus responded also to a shift in the architecture of international aid due to the neoliberal policies that began to be implemented in the 1980s. The NGOs that have become directly involved in development are generally known as development NGOs. Some examples of development NGOs are Oxfam, Lutheran World Federation, CARE, and World Vision. Their efforts involve services that focus on economic, social, and environmental sustainability, local participation, empowerment, ownership, and micro-credit. The projects associated with such focus have been known, whether truly effective or not, for 
their capacity to lift people out of poverty through service delivery and income-generating projects (Riddell, 2007).

During the last three decades, development NGOs grew in size, relevance, and outreach. Riddell (2007) estimates that the number of people directly benefiting from development NGOs was well over 600 million in the early 2000s. Today, this number could be far higher. With the shift of official aid funding from governments to NGOs, it is argued that poor people in developing countries receive more assistance from NGOs' programs and projects than those funded directly by official aid (Galway et al., 2012; Riddell, 2007). In 2006, NGOs received more than 2 billion USD in official development aid (Galway et al., 2012). However, their contribution to development remains debatable. It has not been empirically proven that development goals can be reached only through implementation of projects. Underdevelopment is a structural problem that needs to be addressed by appropriate policies, which start by tackling the underlying structural conditions that keep people in poverty.

Development is a complicated endeavor that requires a complex and multifaceted approach, which NGO projects alone cannot address. A main concern I have with development NGO projects is related to their sustainability. NGOs are wedded to neoliberal capitalist agendas that promote privatization, and thus cause a drastic reduction of the role of the state, and a strong confidence in the market. Pursuing this agenda makes their projects less about sustainability and more about filling the gaps left by the market (Schuller, 2009; Galway et al., 2012). Studies have demonstrated how difficult it is for such projects to be sustained without consistent external support (Oakley et al., Riddell et al., 
1999; Riddell, 2007). Recounting an evaluation of the financial sustainability of NGOs, Riddell writes:

The bulk of NGOs evaluation material, which looks at the issue of sustainability, has concluded that most NGO projects are not financially sustainable without the continued injection of external funds. It is not surprising that the poorer the beneficiaries, the less likely they are to be able to pay for the services, training, and goods provided to them. Indeed, the prospects for financial sustainability of projects examined in the donor-funded study of Finished NGOs- supported projects were judged to be so poor that it was suggested that many development projects were aptly called welfare projects as they consisted predominantly of helping poor people gain access to goods and services that they were unable to pay for themselves. (Riddell, 2007, p. 281).

Alternatively, agenda-setting NGOs and local NGOs may attain more sustainable results, as they are advocating for systemic policy changes. For example, studies support the notion that the work of human rights organizations has often led to changes in the law to protect land rights when lands have been appropriated (Roche, 1999; Landman and Abraham, 2004).

Other successes have been attained in this area of agenda-setting. FUNCOL, a Colombian NGO, successfully worked for land rights for indigenous people (Carroll, 1992). In Ghana, NGOs successfully promoted breastfeeding as an alternative to commercial milk powder (Chapman, 2002). After the end of apartheid in South Africa, many NGOs showed a direct link between their activities and the end of apartheid. These 
results, which arise out of NGOs that are not primarily development-oriented, are more likely to increase capacity and produce development outcomes.

There is considerable evidence to assess the development impact and long-term structural change created by advocacy NGOs that focus on groups such as women and indigenous people. In Columbia, for example, NGOs such as Water for the People have been advocating during the last few decades for local community engagement in water issues. With the help of Water for the People, local NGOs in Cochabamba such Agua Sustentable (Sustainable Water) and Fundación Abril (April Foundation) implemented the eco-toilet project, through which they have designed new toilets using local material and resources. This allows them to lower the cost of toilets from 420 to 250 bolivars (West, 2014). Today, in many parts of Cochabamba, local cooperatives and other community-led groups manage their own water resources. The result has been a major improvement in access to water and sanitation in Cochabamba, as Madeline West (2014) has noted in her thesis on Community Water and Sanitation Alternatives in Peri-Urban Cochabamba: Progressive Politics or Neoliberal Utopia.

At the local level, NGOs can also be crucial in increasing capacity and reducing people's vulnerability. In her study on NGOs in Haiti following the 2010 earthquake, Zanotti (2012) made a compelling argument about the effectiveness of local NGOs. In her ethnography of twelve NGOs in Haiti - ten northern and two local - she concluded that the immediate impact of local NGOs on Haitian people's lives was more apparent than that of the larger northern NGOs.

Even at the local level, differences in NGOs' actions can be seen based on their funding source. For instance, Mark Schuller, an American anthropologist who conducted 
his dissertation research in Haiti, makes a distinctive observation between two local NGOs. They are of similar size, longevity, and in the same line of intervention, but with different donors. One NGO, Sove Lavi, (Save Lives) receives funding from USAID, and the other local NGO, Fanm Tet Ansanm, (Women United) receives most funding from private NGOs donors. Schuller (2012) remarks that "whereas Sove Lavi repeatedly brushed aside member concerns in favor of top-down mandates, triggering local conflicts, Tet Ansam enjoyed relatively high levels of autonomy and member participation," (Schuller, p. 9). Schuller also concludes that according to donors, "Fanm Tet Ansam performed beyond expectations," (Schuller, 2012, p. 47) and that its interventions are more likely to bring long-term outcomes.

\section{Linking Disaster Relief and Development (LDRD)}

The link between relief and development gained greater importance at the end of the 1980s and into the 1990s. Particularly, because of the sharply rising trend in natural disasters during the 90s, funding has become increasingly directed toward relief (Buchanan-Smith and Maxwell, 1994). In Africa and Asia, for example, relief efforts were spurred by growing numbers of emergencies in those regions due to an increase in natural disasters and a food security crisis (Christoplos, 2006; O'Byrne, 2013; Shipper \& Pelling, 2006). As a result, governments and donors increased their relief-assistance budgets. BuchananSmith and Maxwell (1994) report that in southern Africa, relief budgets increased in the 1980s and 1990s. In Ethiopia, for example, the cost of relief was estimated to be 36 percent of the national GDP when the country was hit by famine. Furthermore, every donor with an extensive portfolio also sank more money into relief, such as Britain's ODA, which 
increased its relief budget from two percent in 1982 to twelve percent in 1992. The logic behind this increase was that when relief and development are implemented together effectively, it could provide people with secure livelihoods and safety nets capable of mitigating the frequency and impact of hazards. At the same time, it can ease the process of disaster rehabilitation (Buchanan-Smith and Maxwell, 1994). Throughout the 90s, the discourse linking relief and development promoted a linear one-way transition from relief to development. This approach was known as the continuum model (Buchanan-Smith and Maxwell, 1994; Christoplos, 2006; Mosel and Levine, 2014; Ramet, 2012).

Linking relief and development through the continuum model proved to be very difficult because of the potential for relief to damage development efforts and increase people's vulnerabilities (Anderson and Woodrow, 1998; Janse and Flier, 2014; Ramet, 2012). It became clear that in order for relief to reduce people's vulnerability, new instruments and approaches needed to be implemented. Scholars and aid agencies began to explore the contiguum approach that emphasized a "simultaneous and complementary use of different aid instruments" (Ramet, 2012, p. 4). This model advocated for relief, rehabilitation, and development to happen simultaneously. As a result, new concepts were invented, such as "sustainable recovery," "development-oriented relief," "disaster prevention and preparedness," and the like (Buchanan -Smith and Maxwell, 1994; Ramet, 2012). These were tools intended to, at least rhetorically, reshape the delivery of aid in an attempt to bridge the gap between the acute reaction to disaster and the long-term necessity of vulnerability reduction.

The contiguum approach proved also to be very complicated to put into practice. Part of this complication was due to the fact that disaster relief and development aid 
operated under two different umbrellas. In addition, there are fundamental differences between humanitarian assistance and development aid. They have different sets of goals and objectives. They also have different mandates, are governed by different principles, and operate under different conditions and timeframes (Ramet, 2012).

Also, concerns were being raised about the "grey zone," the funding gap between humanitarian assistance and development aid (Christoplos, 2006; Mosel and Levine, 2014). The long-term efforts aimed at reducing vulnerabilities and promoting development are often underfunded. In the case of post-earthquake intervention in Haiti, for example, Valerie Ramet (2012), in her Policy Briefing to the European Parliament's Committee on Development, diagnosed a serious gap between EU emergency efforts in Haiti and its postemergency intervention. She reported that the reconstruction was inadequately funded (Ramet, 2012 p. 7).

In order to enhance LRRD, Ramet (2012) suggests a "better understanding between humanitarian and development actors, more funding and a reinforcement of existing coordination arrangements," (p. 10). Bringing together humanitarian and development actors is an essential part of the resilience discourse (Mosel and Levine, 2014; Otto and Weingärtner, 2013). A focus on resilience argues for relief and rehabilitation to be integrated in ways that can produce long-term development outcomes. Following the simultaneous treatment approach, the argument of my research is that for disaster aid to reduce vulnerability and produce long-term outcomes, it needs to make development a centerpiece of its intervention by focusing on resilience. Development, in this context, must target the most vulnerable. 


\section{Theorizing Resilience in a Post-disaster Context}

The concept of resilience became prominent in the UN's reports after the Hyogo World Conference on Disaster Risk Reduction. The Conference was held less than a month after the Indian Ocean tsunami that spurred the creation of the Hyogo Framework for Action, which makes building disaster-resilient communities a development goal. In the Framework for Action, the argument was made that "disasters could be substantially reduced if people are well-informed and motivated towards a culture of disaster prevention and resilience," (UN, 'Report,' p. 14).

Building resilient communities requires a determination as to what makes that community vulnerable. As I argued earlier, vulnerability is caused - in addition to other factors - by poverty, income inequality, lack of employment, viable infrastructure, and effective public safety policy. I define resilience as the social, economic, and environmental factors that allow a community to withstand natural events and to quickly recuperate when they occur. Such factors include appropriate municipal infrastructure, protection of the environment, robust public health care system, gender integration, increased financial capacities, promotion of education and disaster awareness, and policies to reduce risk, prepare for, and respond to disasters. Resilience is not the absence of vulnerability. While vulnerability implies the incapacity of a community to withstand the

effects of natural events or man-made hazards, resilience relates to the capacity for a community to mitigate, and then quickly recover from the effects of an event. This nuance between resilience and vulnerability departs from John Twigg's approach that views resilience and vulnerability as "opposite sides of the same coin," which implies the more vulnerable is a community, the less resilient it is and vice versa (Twigg, 2009, p.3). Instead, 
I argue that vulnerability and resilience may be two sides of the same coin, in the sense that less vulnerable communities are more resilient. In this way, in the face of vulnerabilities, resilience relates to the capacity to recover quickly. So, one does not indicate the other; but less vulnerability makes communities and people more resilient. Thus, resilience can function through capabilities for effective responses to disasters even under conditions of vulnerability.

\section{Financial Resources}

Therefore, building resilient communities largely depends on implementing policies and practices that enable vulnerable communities to withstand a disaster and facilitate recovery. Based on that consideration, a community that appears to be vulnerable may be more resilient than one that appears to be resilient in the first place. A comparison between Cuba and the United States proves that Cuba is much more resilient than the United States (for example, it is able to move the population out of harm's way) even though it may be more vulnerable in some respects (Lizarralde et al., 2014). As evidenced, in September 2004, a tropical storm killed more than fifty people in the United States, while Cuba had no deaths. Hurricane Charley, still in 2004, caused the deaths of thirty people in Florida, but killed only four people in Cuba. Hurricane Katrina killed more than 1800 people in the USA, but no one was killed in Cuba, although the Hurricane destroyed 20,000 homes in the latter country (Lizarralde et al.; Smith, 2007).

Cuba's demonstrated resilience led the UNDP to propose Cuba as a "model" for disaster management and resilience in the Caribbean. "At the heart of the model is the promotion of local level decision-making that relies on coordinated early warning systems, 
risk and vulnerability studies, communications systems, effective database management and mapping, GIS, and community preparedness," (UNDP, 2015). Based on that model, I propose a two-fold approach that can build and strengthen resilience indicators to disaster and concurrently put in place sustainable development policies with an emphasis on disaster risk reduction management initiatives and community development.

\section{Resilience Indicators}

The "resilience indicators" can help assess a community's level of resilience and can be acted upon to build a more resilient community. Below, I consider each indicator separately.

\section{Municipal Infrastructure}

Municipal infrastructure is one important determinant in building a resilient community. Developed countries adapt their infrastructure to hazards and risks. They do so with technology (Dore and Etkin, 2003; Duffield, 2010; Grove, 2013; 2014; Reid, 2012; Ward \& Shively, 2017). The most important aspect of such adaptation is determining how infrastructure was deficient prior to the damaging event. In developing countries, most disaster-related damage is caused by inadequate drainage, construction in unsafe zones, building without attention to safety codes, and deficient roads or roads that provide limited access to first aid intervention (World Bank, 2003). Following a disaster, such vulnerable infrastructure should be identified, and resilience should be increased by enforcing new building codes and creating new infrastructure capable of withstanding or at least 
mitigating the consequence of future disasters. In other words, resilience depends on anticipating weaknesses and vulnerabilities, and then taking measures to correct them in ways that can build capabilities to recover from the negative effects of disasters produced by existing vulnerabilities.

\section{Reforestation}

Flood is the most significant cause of disasters in the Caribbean, particularly in Haiti (reference to this point). Much of this risk can be attributed to deforestation. Numerous studies have shown that the presence of vegetation can significantly reduce the downstream transmission of flood waves and thus prevent catastrophic flooding events (Abernethy and Rutherfurd 2000; Brooks et al. 2003; Brooks and Brierley 2002; Hickin 1984; Thorne 1990). On top of this, lack of riparian vegetation and human alteration of rivers can produce catastrophic erosion and landslides during large magnitude floods (Brooks and Brierley 1997; Brooks and Brierley 2000; Thompson and Croke 2013). Thus, we must ask the question: to what extent do deforestation and lack of vegetation contribute to disasters, and how can we build the ability to predict, anticipate, and respond to catastrophic erosion, landslides and floods as a result of deforestation? And how resilience is built or increased at these levels?

\section{Public Health}

Public health refers to physical health infrastructures such as hospitals and clinics, but also the management of healthcare systems and the efficacy of care (McEloy, Ann and Townsend, Patricia K., 2015). Following a disaster, a robust public health system can 
facilitate the recuperation of its victims. It may also allow the community rehabilitation process to occur more rapidly. On the other hand, a weak public health system hinders the process of rehabilitation and may provoke subsequent disasters. When a disaster strikes, people often perish as a result not of the event, but rather of inadequate healthcare. It has been observed that after a disaster, disease and infection tend to spread, and such conditions, if not managed properly, may lead to disastrous epidemics (Margaret et al., 2015).

Following a disaster, the questions that should be asked are: to what extent has the public healthcare system failed to save lives and prevent future epidemics? How can resilience be built in to prevent future health care crises? We must keep in mind that health care infrastructures are expensive; insufficiency of resources may impede the building or rebuilding of appropriate healthcare infrastructure after a disaster. However, prevention is better than healing, so building healthcare resilience may begin first by prioritizing prevention, encouraging good hygiene health practices, and developing food security. In this way, building resilience may require the promotion of primary care, building local clinics, training primary health care personnel, and facilitating access to essential medications (Margaret, 2015).

\section{Education and Disaster Awareness}

Education in this context refers to the standardization of disaster response (Anderson and Woodrow, 1998). In times of crisis, survival instincts often cause people to make adverse decisions. Education and disaster awareness are intended to promote good practices and lay out the behaviors that are most effective both prior to and in the wake of a disaster. It 
aims to increase public understanding of risk, vulnerability, and disaster reduction. It encompasses, for example, educating a population about seismic norms, respecting building codes, providing basic first aid, and understanding the causes of natural hazards and the effects they might have on communities (Allen, 2003; Anderson and Woodrow, 1998; Bankoff, 2008). Education, however, is not enough without public policies and proper legislation. Human beings will often engage in risky behaviors and enforce laws in order to set boundaries and limit adverse actions. Building effective resilience in this category first requires that we ask: in what way are people vulnerable due to a lack of disaster awareness, and how can we create conditions for people to learn and be prepared to withstand the next disaster?

As I argued earlier, people are often vulnerable because of poverty, precarity, and lack of financial resources. Lack of financial resources includes unemployment, limited access to credit, absence of protection against risk, savings depletion, and lack of job security and insurance. The level of financial resources of an individual or a community closely aligns with the speed at which the individual or community will recover in the wake of a disaster. Building financial resilience requires necessary policies that the population can access during cases of financial institution collapse. In developed countries, people's livelihood and properties are protected through diverse forms of insurance, retirement savings, and government protection (Black, A. \& Evan S. 1999; Salt, 2003). However, in some developing countries - like Haiti - populations are living without any form of protection against natural events, and thus their livelihoods often vanish in the wake of disasters. 
Lack of financial resources often constitutes one of the underlying factors in a disaster. Because of lack financial resources, people build houses in hazardous areas, use poor materials, and cut down trees for economic survival. When disaster strikes, they are unable to cope or bounce back. To build a financially resilient community, we must determine to what extent a population was financially vulnerable before a disaster. How was the financial vulnerability of the population manifested? Furthermore, what are the structural factors that rendered this population financially vulnerable?

\section{Gender Integration}

While natural events are not gendered, disasters are. Furthermore, the mere fact that an individual is a woman does not necessarily make her more vulnerable to any catastrophe or natural hazards (Bradshaw, 1998). However, if vulnerability is often caused by lack of resources, poverty, income depletion, and other material and socioeconomic inequalities, the mere fact that women are more likely to be affected by those factors render them more vulnerable than men. Thus, vulnerability to an event is exacerbated by the subaltern position of women in a given society, and their disadvantage may influence how they perceive and respond to risk compared to men (Gustafson, 1998). As Bradshaw (2014) points out, the lack of information, education, and engagement with preparedness activities that women face may limit their capacity to act when an event occurs. It therefore makes them more vulnerable and less resilient. Even after they survive a disaster, women (and particularly low-income women) face greater employment insecurity than their male counterparts (Bradshaw and Fordham, 2013). 
A successful relief effort needs to consider in what way women were disadvantaged before the event. To what extent did they participate in decision making before the event? And how did their economic conditions and lack of education impact their ability to act and respond to the catastrophic event?

\section{Risk Reduction and Preparedness}

Risk refers to "the probability of harmful consequences, or expected losses (deaths, injuries, property loss, livelihoods, economic activity disrupted or environment damaged) resulting from interactions between natural or human-induced hazards and vulnerable conditions," (UN, 2004). This definition implies that exposure to hazard is not enough to put people at risk, but vulnerability is also a determining factor. Here, vulnerability involves the social, economic, and environmental processes related to disaster response and recovery. There is a close relationship between risk reduction and disaster preparedness. Research has shown that disaster effects are mitigated when disaster awareness increases and early measures are taken -- such as early warnings and temporary evacuation of people and property from hazard-prone areas -- to ensure adequate response to the impact of hazards (Alexander, 2013; Lazarralde et al., 2014; Twigg, 2009). Disaster risk reduction (DRR) and preparedness requires the development of a culture of safety, and also that the public is informed on where to build and where not to, the rules of hygiene, the protection of the environment, and the acceptance of shared responsibility and cooperation by community members. All these factors aim toward reducing vulnerability to disaster while dealing with the conditions that trigger them in the first place (Twigg, 2009). 
However, the promotion of risk reduction measures and disaster preparedness is a matter of public policy accompanied by effective implementation. This requires a focus on development. As such, efficient relief efforts should integrate building resilience with a focus on effective DRR programs. As Twigg argues, "there is very wide-ranging and there is potential and need for DRR initiatives in just about every sector of development and humanitarian work.” (Twigg, 2009; p.9). Thus, DRR relates both to the reduction of vulnerabilities and the building in of resilience. Both have to go into policy, planning, and practice.

\section{Building Resilience Through Disaster Relief: A Development Goal}

Disaster relief, although intended to alleviate the suffering of disaster victims, can harm a community in the long run. It has been argued that the impact of disaster relief on a population could be as damaging as the original disaster (Anderson and Woodrow, 1998). Because vulnerability precedes disaster and tends to increase after a disaster strikes, it is crucial for relief to be provided in ways that do not increase the severity of vulnerability, but instead concurrently address them. If vulnerability is not addressed while providing relief, it may lead to future disasters. In order to prevent disaster relief efforts from causing more harm by intensifying vulnerability and undermining capacities for resilience, there is the need to make development a centerpiece of its goals.

Building resilience to disasters has been included in development discourses since the UN's 2005 report on the Hyogo world Conference on Disaster Reduction. It was understood that development, viewed as growth and accumulation, could cause vulnerability to disasters. The integration of resilience in development goals has opened 
new windows for sustainable development opportunities. The concept of sustainable development emerged from the Brundtland report "Our Common Future," which defined sustainable development as "development that meets the needs of the present without compromising the ability of future generations to meet their own needs" (UN, 1987).

Most recently, in 2015, the UN General Assembly adopted the 2030 "Agenda for Sustainable Development," which articulates a framework for peace and prosperity for people and the planet, now and in the future," (UN, 2015). This framework targets seventeen sustainable development goals, (SDGs) including good health and wellbeing, quality education, gender equality, good jobs and economic growth, clean water and sanitation, poverty reduction, and sustainable cities and communities. Effective disaster efforts must take those goals into account when delivering relief and building rehabilitation.

\section{Toward a New Development Perspective: The Role of NGOs}

The concept of development has significantly evolved over the last few decades. Since World War II, its meaning has changed many times. Numerous scholars, mostly economists, have equated development with economic growth. In fact, until today, the most common measure for economic development continues to be the Gross Domestic Products index (GDP), which measures a country's national output and expenditure. Nevertheless, development is not confined only to economic growth, it also considers the social welfare of the people (Degnbol-Martinyssen and Engberg-Pedersen, 2003; Goldin, 2016; Peet and Hartwick, 2009; Sen., 1999; Thorbecke, 2006). 
Peet and Hartwick (2007) write: "Development means creating a better life for everyone. In the present context of a highly uneven world, a better life for most people means, essentially, meeting basic needs: sufficient food to maintain good health, a safe, healthy place to live, affordable services available to everyone, and being treated with dignity and respect" (Peet and Hartwick, 2007; p.1). This idea of development is largely covered in the UNDP Development Index.

Amartya Sen (1999) viewed development as capabilities and substantive freedoms that people must enjoy in order to live a full life. Although increasing income is one of the capabilities, a focus on development as freedom recognizes that development is not only about income and growth. Rather, it is mostly about the freedom that people must achieve a desired end with the income they have at their disposal. This approach also recognizes the expansion of freedom both as the primary goal and as a principal means of development. Development, when viewed in this way, consists "of the removal of various types of unfreedoms, that leave people with little choice and opportunity of exercising their reasoning agency" (Sen, 2002; p. xii). While Hintzen (2019) agrees with Sen's approach of development as freedom, he argues that the realization of such freedom can be possible only under conditions of effective democracy and good governance. In his article, Towards a New Democracy in the Caribbean: Local Empowerment and the New Global Order (Hintzen, 2019), Hintzen stresses that "in the West Indies the instrumentality of "democratic governance" has systematically limited, constrained, and/or foreclosed the imperative of freedom and conditions for the realization of true development." Therefore, there is a need to transform the social and economic "processes" to produce more capabilities under the conditions of effective democracy freed from existing constraints. 
My research draws on Anderson and Woodrow's approach that views development as the process by which capacities are increased, and vulnerabilities decreased. Vulnerability is viewed here not only as social and cultural, but also as physical and economic vulnerabilities. It refers to "a set of prevailing or consequential conditions composed of physical, socio-economic factors that adversely affect the ability to respond to events" (Periperi in Delica-Willison and Willison, 2004). Vulnerability is a more significant concern for the poor, as the poor are often the most vulnerable. Moreover, the social and cultural processes that foster vulnerability are primarily the products of international and national political economy (Cannon, 1994).

Development both causes and prevents vulnerabilities. Analyzing development through the lens of capacity and vulnerability provides insight into the relationship between NGOs (in their various forms) and development, and the differences in NGOs' actual and potential contributions to development regardless of the type of actions in which they are engaged. I decided to focus on Haiti because of the extraordinary role NGOs are playing in every aspect of the functioning of the country. NGOs are central for disaster relief in Haiti. Following the January 2010 earthquake, NGOs have been managing almost all disaster aid that the country has received.

\section{Summary}

In this chapter, I reviewed the scholarship on disaster relief, development, and NGOs. Critical to this research is the distinction between extreme events and disaster. The former is the product of nature, and the latter is produced by structural factors. The possible transformation of events into disasters and eventually calamities is primarily contingent on 
the degree of development of the space where those events have occurred. Development, here, is not seen as growth and accumulation, but rather as the process through which vulnerability is decreased and capacity for resilience is increased. I also reviewed the intensity of the scholarship on disaster relief, development, and NGOs. Therefore, I emphasized that disasters often occur because of lack of development, and often affect the most vulnerable. My main argument is, then, if disasters occur because of lack of development, then disaster aid must be delivered in ways that can build development and produce resilience to future disasters. Arguably, disaster assistance must open the door to strategies of development that focus on the most vulnerable. 


\section{Chapter Three: The Parallel State: Neoliberalism in Haiti and the Reliance on NGOs}

This chapter analyzes the implementation of neoliberalism in Haiti. In the chapter, I consider two main phases of the implementation and the social and economic implications of each phase. The first phase provoked a depeasantization of the country. The second was marked by the privatization of most of the state-owned enterprises. Although this phase accelerated the urban migration that began in the first phase, the most pervasive consequence of the second phase was the weakening of the Haitian state.

\section{The 1980s: The Beginning of Depeasantization process in Haiti}

In the first phase of the implementation of neoliberalism in Haiti, particularly between 1986 and 1988, the United States, particularly USAID, along with the World Bank and the IMF used their collective and significant influence to compel the Haitian government to open the country's economy to global capital and to eliminate import restrictions on goods and services (Dupuy, 2005, 2014). This had devastating consequences for the Haitian economy even though, in the initial phase of this process of liberalization, some jobs were created in the manufacturing sectors. It destroyed agricultural production and increased Haiti's food dependency, particularly on the United States.

Prior to 1985, the Haitian economy was based primarily on agriculture. The agricultural sector employed about 70 percent of the active population and contributed 35

percent to the country's GDP (Arthur, 2002). By 1988, subsidized food from the U.S. flooded the Haitian market. For example, between 1986 and 1995, there was a dramatic 
increase in imports of rice from 5,000 to nearly 20,000 metric tons. This was also the case for sugar, coffee, and other agricultural products (Klarreich and Polman, 2010; Dupuy, 2014).

Before 1960, Haiti was self-sufficient in its domestic food production (Moral, 1961). The country began to suffer from declines in food production beginning in the 1960s, even though, until the seventies domestic production contributed to most of the country's food supply. By 1981, Haiti was importing 23 percent of the country's food supplies. These figures doubled during the 1990s and tripled in the 2000s. Today, about 80 percent of the rice consumed in Haiti is imported from the United States (Dupuy, 2014). Beginning in the 1980s, the average cost of imported food began to drop below that of locally produced food. Faced with lower-priced competition, Haitian peasants could no longer compete with food imported from the United States. This left them with two choices: Leaving the country altogether or migrating to urban areas (Charles, 2002). Many Haitian peasants sold their land and joined an exodus from the country as waves of migrants- many, using small and fragile boats- sought to immigrate to the United States. According to U.S. Immigration and Naturalization Service (INS), an estimated 95,000 Haitians immigrated to the United States during the early 1980s. Thousands more perished at sea as they desperately tried to join other undocumented migrants (Charles, 2002). Other farmers abandoned their land and many of them migrated in masses to Port-au-Prince, in search of manufacturing jobs. This rural - to - urban migration led to a process of depeasantization as rural residents who were unable and unwilling to migrate overseas overwhelmed the cities and swelled their slums. The process of depeasantization was so significant that it exceeded the capacity of the growing manufacturing sector to absorb the vast majority of 
the displaced peasants. This confirmed Phillip McMichael's argument that "depeasantization does not itself create a global labor force; it simply swells the ranks of displaced people lacking needs of subsistence and needing wage work," (McMichael, 2008, p. 96).

In the early 1980s, the manufacturing industry in Port-au-Prince could employ only 60,000 people, though the population of the city rose substantially (Dupuy, 1997). In 1971, the population of Port-au-Prince was estimated to be 493,932 (Microtrends, 2020). In 1982, the population jumped to 763,188 (Microtrends, 2020). Thus, Port-au-Prince's job market could not nearly accommodate the rapid influx of job seekers. This rapid urbanization and depeasantization was, however, a new phenomenon in Haiti. Up to 1989, Haiti had the lowest ratio of urban to rural population in the Caribbean and Latin America. With a population of over 6.1 million people in 1990, only 25 percent lived in urban areas compared to 70 percent in Latin America (Arsht, 2014). This trend would reverse in the decade of the 1990s.

It is important to note that the destruction of agriculture also impacted the environment. As peasants could no longer compete with the imported food market, they began to cut trees for economic survival by producing charcoal, Haiti's primary energy source, to satisfy the energy demands of the rapidly growing urban population. This resulted in severe deforestation that caused excessive soil erosion and devastating floods. The latter has now become one of the most common weather-related catastrophes in Haiti (Singh \& Barton-Dock, 2015). 


\section{The 1990s: The Weakening of the Haitian State}

The implementation of neoliberal policies in Haiti accelerated during the 1990s. In 1991, a leftist Priest, Jean Bertrand Aristide, was democratically elected president of Haiti. Six months after he was sworn in, he was ousted from power by a military coup. After spending three years in exile in the United States, Aristide was returned to power by a U.S.-led multinational force. During the years of military rule following the coup, development aid and programs were put on hold, and an international economic embargo was placed on Haiti. The embargo had severe, devastating consequences for the country's economy. It resulted in the closure of most of the factories and assembly industries in Port-au-Prince, and nearly all of the workers were laid off. The country's GDP fell by 26 percent (Dupuy, 2014). This put the country in desperate need of overseas economic assistance.

President Jean Bertrand Aristide returned to office on October 15th, 1994. As a main condition of his return, "Aristide was compelled to accept the Emergency Economic Recovery Program (EERP) devised in Washington by a multinational task force of the IDB, the World Bank, the IMF, and the USAID" (Dupuy, 2014, p. 57). The EERP was a reformulation of former neoliberal policies. Because of parliamentary opposition and widespread protests, Aristide was not able to implement the policies. As a result, the international community withheld aid to his government but increased NGO funding.

In 1996, René Préval, Aristide’s former Prime Minister, became president. He found himself in desperate need of international aid2, and was pressured by the IFIs to

2 International Financial Institutions forced President Préval to initiate the privatization process. The implementation of privatization policies was an essential condition for the release of economic aid. When, under popular pressure, he decided to put the privatization process on hold, aid promised to the Haitian state was frozen. This situation continued until the end of President Préval's mandate and throughout 
implement the EERP. In October 1996, Préval entered into an agreement with the World Bank and the IMF, according to which the government agreed to undertake the following reforms: 1) reduce tariffs for foreign companies, 2) reduce the size of public services, 3) privatize state-owned enterprises, 4) grant tax benefits to private capital (for example, exempting it from taxation for three years), and 5) create enclave industrial areas (PierreEtienne, p. 86).

This agreement was praised by the World Bank proclaiming "the government has made significant efforts to maintain macroeconomic stability, which need to be continued and strengthened" (Dupuy, 2005, p.61). By 1999, some major public enterprises were privatized, and international tariffs were either reduced or eliminated. The privatization of state-owned enterprises in Haiti was intended to open Haiti up to foreign direct investment for export production. It served to increase Haiti's dependency.

Many of the state-owned enterprises that were privatized were profitable, or potentially profitable, at the time of their privatization (Crémieux; 1996; Dupuy, 2015). For example, one company, Haiti Cement (Le Ciment d'Haiti) produced between 250,000 to 450,000 tons of cement per year before it was privatized. During the 1980 s, the company boomed, transferring about 42 percent of its profits to the public treasury. However, an embargo was placed on Haiti from 1991-1994, forcing it to close down.

Aristide's second term of office (1997-2004). The privatization process did not resume until March 2004, under the leadership of President Boniface Alexandre and Prime Minister Gerard Latortue, who replaced Aristide after he was ousted from power. Under Alexandre's and Latortue's leadership, the privatization process resumed under the terms of the Interim Cooperation Framework (ICF), which was signed by major donors in Haiti. 
The embargo on Haiti and the decision to lift it can be explained by a convergence of political and economic interests on the part of the United States. It was initially imposed for punitive political reasons but was rescinded under the imposed neoliberal conditionalities that drove U.S. foreign policy and that was agreed to by the government of Haiti. These imposed conditionalities provided U.S. investors with the opportunity to acquire profitable Haitian enterprises. A typical example is, The Minotrie d'Haiti, a flour company that was forced to close in 1992 during the embargo. At the time the company was producing between 135,000 and 150,000 tons of flour per year and was highly profitable. Between 1980 and 1990, 90 percent of its profits were transferred to the public treasury. In June 1997, after the embargo was lifted, the company was sold to two U.S. multinational companies (the Continental Grain Company and the Seaboard Corporation) and to one Haitian company (the SNI Minoterie SA, a subsidiary of the UNIBANK, which is a private bank in Haiti). This was the typical fate of many other public enterprises that were sold under the Preval's Administration, during 1996-2001.

The purchase of local companies was a strategy employed by foreign interests to use their infrastructure as a springboard to gain control of the country's economy. This was achieved to the detriment of local workers who were laid off. Many of the acquired companies were closed and their sites were used as warehouses for imported food products. In 2001, because of its neoliberal policies, Haiti became recognized as one of the most open and liberal markets in Latin America3.

3 Marc Bazin, Government Comments (B): English version p. 70-71. Marc Bazin was the presidential candidate that the US supported in the 1990 elections (that eventually led Aristide's election). Marc Bazin was a former employee of the World Bank. When Aristide returned to power in 1994, the US required that he nominate Marc Bazin as Minister of Planning and External Cooperation. 
Agreement to accept neoliberal policies by the Haitian government was partly secured through the withholding of badly needed aid, both under the Aristide presidency at the beginning of Préval's. Nonetheless, direct assistance provided to the Haitian government declined significantly even after the implementation of neoliberal policies. The IMF, the World Bank, and the United States instead shifted funding to NGOs. Marc Bazin, former Minister of Planning and Cooperation during the 1990s, wrote:

The liberalization effort has taken place virtually without a decent level of international aid and Haiti has paid a very high price for its foray into globalization, given, in particular, the inadequacy of human and physical resources, as reflected, in particular, in higher unemployment, reduced purchasing power, greater inequalities, and low per capita food production" (Bazin qtd in Dupuy, 2014; p. 62). The demographic impact of Haiti's liberalization program was also significant, as the process of depeasantization continued to accelerate. From 1995 to 2000, Port-au-Prince (the greater Port-au-Prince area) population increased from $1,427,000$ to $1,693.000$ (Microtrends, 2020). This trend continued throughout the 2000s, at a rate of 75,000 people per year (USAID, 2007). At the time of the 2010 earthquake, Port-au-Prince had 2, 643.000 (Microtrends, 2020) residents, which represented 25 percent of the country's population (Zanotti, 2010; HISI, 2014). Without formal employment, most of the population was earning their livelihood from the informal economy, which employs more than 80 percent of the Haitian workforce and were relying on remittances from the Haitian overseas diaspora. Most public services, at the time, were being provided through NGOs.

My argument, thus far, is that neoliberalism produced depeasantization and destroyed domestic production of goods and services, and especially domestic food 
production. Haiti moved from food self-sufficiency to become dependent on imported food. Urban manufacturing was unable to absorb displaced rural labor, and this contributed to massive outmigration, dependence on the informal economy and remittances from abroad. Neoliberalism also reduced the capacities of the government to cater to the needs of the population leading to dependence on NGOs.

Privatization was described by the International Financial Institutions (IFIs) as a recipe to strengthen macroeconomic stability, encourage private sector investment, and increase productivity. As the World Bank report, "Haiti: The Challenges of Poverty Reduction" (World Bank,1998) stated:

Boosting private investment will provide the underpinnings of Haiti's future economic growth. A first important step will be the implementation of the capitalization program, telecommunications, electricity, water sector, ports, and airports. Privatization of these sectors would increase the productivity of the economy and provide a clear signal as to the Government's commitment to redefining the role of the state and set the economy on a modern course. The Government has made significant efforts to maintain macroeconomic stability, which need to be continued and strengthened (World Bank, 1998 p. vii)

However, at the same time, the report highlighted the impact of such policies on the capacity of the state to invest in social programs for the poor. The Bank recommended that the NGO sector provide the services that were part of the functions of the state. The Bank wrote:

A huge challenge for the Haitian state will be increasing resources allocated to the finance of social service provision. In education, health, water and sanitation, and 
family planning, Government should continue to leave the delivery of these services to the private and/or NGO sectors to the maximum extent possible, while the government itself strives to improve the regulatory framework, facilitate coordinated efforts among its activities, those of private actors, and the poor themselves. Limited government resources should be directed at programs that are targeted to the very poor, particularly those in rural areas which have been neglected in the past. Until the benefits of these longer-term investments in human capital are felt, the existence of targeted transfers and social safety net programs will continue to be important to the survival of the Haitian population. (1998, p. vii).

The benefits expected from the implementation of these liberalization policies have yet to be realized. Instead, poverty persisted in Haiti. The per capita income that was USD 632 in 1980 fell by USD 332 in 2003 (Verner, 2007). Haiti entered the decade of 2000s with disappointing GDP growth of 0.7 percent in 2000, followed by two years of negative growth of -1.04 in 2001 and -0.25 in 2001 . There was a slight increase to a positive growth rate, which slightly bounced to 0.36 percent in 2003 (World Bank, 2020). Extreme poverty remained. In 2001, 49 percent of the population, totaling 3.9 million people, was living under the condition of extreme poverty (Verner, 2007). These were the conditions at the time when NGOs had begun to take over almost all of the government services.

\section{The Proliferation of NGOs}

The proliferation of NGOs in Haiti occurred in two waves. The first wave occurred during the 1980s. It was triggered by humanitarian concerns and concerns over government 
corruption. The second wave occurred during the decade 1990s and 2000s. This wave was triggered by declines in state capacity as a result of the implementation of the neoliberal policies in Haiti. During this period, the proliferation became significant and produced a shift to complete reliance on NGOs.

The First wave and the Increase Presence of NGOs in Haiti

NGOs have been providing services in Haiti since the 1950s. The Cooperation for Americans Everywhere (CARE) and the Catholic Relief Service (CRS) were among the first NGOs that began to deliver services in Haiti and were followed by a few Christian NGOs in the1960s. During the 1970s and 1980s, the Number of NGOs began to increase in Haiti. (Pierre Etienne, 1997; Pierre Louis, 2012). In 1971, Jean Claude Duvalier became president of Haiti, succeeding his father, Francois Duvalier. The young president pledged to engage the country in economic progress. While the beneficiaries of his policies were the political and economic elites, most of the population sunk into poverty, and many into starvation (Trouillot, 1987, Charles, 2002). This led to an eruption of food riots at the beginning of the 1980 s.

The escalation of poverty and starvation attracted international attention, particularly in the wake of an exodus of Haitians attempting to migrate by sea during what came to be known as the "boat people crisis. Many of them died in the attempt. This loss of human lives troubled the international public. Extensive media coverage of the situation led NGOs to increase their presence in Haiti, while the United States and European countries increased financial assistance (Pierre Etienne, 1997). 
Because of the well-deserved reputation of corruption of the Haitian government, the international community bypassed the state and provided aid directly to NGOs for distribution to the people. In 1988, Brinkerhoff and Goldsmith wrote in their article The Challenge of Administrative reform in post-Duvalier Haiti: Efficiency, Equity and the prospects for Systemic Change.

Faced with a national administrative network that lacked modern skills and was riddled with corruption, most external agencies in Haiti in the 1970s and 1980s chose to work around the central administration, either by collaborating with NGOs or by setting up autonomous public bodies over which they could exercise close oversight (Brinkerhoff and Goldsmith, 1888, p.14).

The trend of bypassing the government continued, even after the fall of Jean Claude Duvalier in 1986. However, until the end of the 1980s, the number of NGOs operating in Haiti remained relatively low. According to the 1987 World Bank report, the number of NGOs in Haiti was estimated to be 300. More significant increases occurred during the 1990s.

\section{The Second Wave and The Shift to A Complete Reliance on NGOs}

In 1997, Sauveur Pierre-Etienne published his book, "Haiti: The Invasion of NGOs," to bring public attention to the increased presence of NGOs in Haiti. He estimated the number of NGOs working in Haiti at the time to be 800 . During the decade of 2000 s, the proliferation increased significantly. By the time of the earthquake in 2010, the number of 
NGOs operating in Haiti had risen to roughly 10,0004 (World Bank, 2009; Klarriech, and Polman, 2010; The Economist, 2010), giving Haiti the second-highest number of NGOs per capita in the world following India.

The rapid increase of NGOs in the 1990s and the 2000s was symptomatic of a larger phenomenon. At the global level, international donors began to circumvent Third World governments and to increase their funding for NGOs. The 1990s saw a sevenfold increase in NGO's official aid funding worldwide, from\$1 billion USD in 1970 to \$7 billion USD in 1990 (Ahmed and Potter, 2006). As funding was funneled into NGOs, their global presence rose rapidly, from 6,000 in 1990 to an estimated 60,000 in 1998 (Reagan, 2003, p. 3).

Two fundamental underlying reasons can explain the increase in official aid to NGOs and the global increase in their numbers: an international debt crisis and the neoliberal policies that began to be implemented in the 1980s. As a response to a significant increase in the amount of foreign debt and national debt held by countries in the global south, the IFIs imposed structural adjustment regimes on indebted countries under strict conditionalities that had the effect of changing significantly state social priorities (McMichael, 2008). NGOs were seen as alternatives to the state because, it was argued, that they are more cost-effective and more capable than the state in reaching out to the poor (David Lewis, 2006; Ahmed and Potter, 2006). With neoliberal policies demanding a

4 The Haitian government has no control of the number of NGOs in the country. Most of the NGOs are not registered. Only about 500 NGOs are currently registered in the Ministry of Planning, the government entity in charge of regulating NGOs in the country 
rolling back of the state, NGOs became compelled to fill the gap (Drabek, 1987; Galway, Corbett and Zeng, 2012; Schuller, 2009).

The increase of NGOs in Haiti followed a global trend. This was spurred by neoliberalization. Its implementation in Haiti in the 1990s led to the almost total collapse of the state and to a heavy reliance on NGOs. As the country came to rely almost exclusively on NGOs, they became increasingly influential players in its political economy.

\section{NGOs in Haiti: The Construction of a Parallel State}

Scholars such as Aiwa Ong, James Ferguson, and Trouillot, in the wake of neoliberalism, have questioned the constitution of the state and its relationship to national governance. Particularly, Trouillot (2001) has observed in the context of globalization that the state has become fragmented and diffused. Trouillot's argument is not an absolute assertion that national governments are no longer relevant. However, their functions have been transformed into the service of global capital as they provide the necessary legalities and authorize the presence of transnational processes and practices. "State effects" are made possible through the national government apparatus, as well as, particularly in the global south, through powerful international institutions. By state effects, I refer to Hintzen's definition "the actual effects of the processes and practices of power on the material lives of people and on their subjectivities, exercised either directly in the deployment of the technologies of global power or indirectly through the authority of the national apparatus of governance" (Hintzen, 2020, p.185). When taking into account the increased 
relevance of NGOs in the global south as it relates to fragmentation of the state power, the question I pose, then, is: What is left to the role of the state in developing countries?

To begin to answer, I would like to point to the shift in the architecture of aid and the way this has deeply changed the mission of NGOs during the last two decades. After World War II and until the 1970s, the mission of NGOs was fundamentally humanitarian (Riddell, 2007, Pierre Louis, 2011). By the 1980s, however, they began to become engaged in other activities, including development. Kim D Reimann (2006) in his article A View from the top: International Politics, Norms and the Worldwide Growth of NGOs notes that before 1988, only 6 percent of World Bank development projects were implemented through NGOs. By early 1990, this number rose to 30 percent. During the late 1990s, 50 percent of the World Bank projects were implemented through NGOs (Reimann, 2006, p. 49). With the UN reductions of poverty agenda and sustainable development goals, NGOs have become even more engaged in development and poverty reductions. Increasingly, funders and development agencies are shifting their funding allocations to NGOs (Reimann, 2006).

In Haiti's case, as neoliberal policies became more extensively implemented during the 1990s and early 2000s, aid increasingly shifted to NGOs. This shift increased their relevance and influence in such a way that some scholars, most notably Mark Schuller (2007, 2012), have portrayed them as functioning as a "parallel state." Schuller, in his book, NGOs in Haiti: Killing with Kindness, made this observation:

The earthquake exposed the weakness of the state... The state has no ability to prevent the disaster or coordinate the relief efforts. The government had been weakened since the mid-1990s by donor's policies of giving their aid directly to 
NGOs. Even before the earthquake, more than 80 percent of the health clinics and 90 percent of schools were private, run by individuals, missions, and NGOsparticularly the large food distribution agencies like World Vision, CARE (Cooperative for American Relief Everywhere), or Catholic Relief Servicesbecame parallel states, even marking off territory into their area ( Schuller 2012, p.6)

There is a great deal of discussion about the relevance of the state in the age of globalization as mentioned earlier. The Haitian Anthropologist Michel Rolph Trouillot, has attempted to explore the transformational role of the state during the last decades. In his seminal work, The Anthropology of the State in the Age of Globalization: Close Encounters of a Deceptive Kind, Trouillot distinguished the state from national government. He depicts the state not as a site or an apparatus of government, but rather as a "set of processes and practices" (Trouillot, p.130). Based on his unconventional approach, he points out what he identifies as a displacement -- a move away from the national power in the age of globalization-. He argues that state power is diffused and transferred beyond the site of national governments as other institutions began to act in a state-like manner. Trouillot writes, "statelike processes and practices also obtain increasingly in nongovernmental sites such as NGOs or trans-state institutions such as the World Bank. These practices, in turn, produce state effects as powerful as those of national governments" (Trouillot, 2001 p. 130).

James Ferguson (2006) makes a similar observation in pointing to the emergence of new forms of government through NGOs and transnational networks. In the case of Africa, Ferguson points out that humanitarian organizations such as Oxfam, CARE, or Doctors Without Borders perform state-like functions (Ferguson, 2006). He argues that 
those organizations do not replace the state, which has far from disappeared. He affirms that they act unquestionably in a state-like manner in many aspects. Trouillot (2002) further affirms that nongovernmental sites such as NGOs or trans-state institutions such as the World Bank produce state effects that are even more powerful than national governments.

If I place my question in the context of the heavy presence of powerful NGOs in developing countries, and thus transnational corporations, the IFIs, and bilateral control of their economies and other multilateral presences, it is no exaggeration to assert that the national government in many developing countries has become a "shadow state." The concept shadow state was used initially by Williams Reno (1999), to reference the way officials in the weak states of Africa gained power through concealed alliances with warlords, arms traders, and multinational firms, instead of through more formal processes used by Western democracies (Reno, 1999; Ferguson, 2006). In a general sense, the word "shadow" describes a doubling -- a copy of something real (Ferguson 2006, p. 16). Likewise, and for the same reasons Georges Fouron (2001) considers Haiti to be an apparent state, which implies that the primary functions of governance are other powerful forces such as influential international NGOs.

NGOs cannot replace the state. Whether a shadow or an apparent entity, the national government will continue to be consequential in many aspects as it continues to maintain what Hintzen calls strategies for regime survival, through the use of ideology, patronage, control, and coercion (Hintzen, 1998, pp. 10-12). Regimes use the national apparatus of governance to control many functions such as the military and police, constitutionality and legality, legislation, the judiciary etc. My argument is that, as a consequence of neoliberalism, there are processes and practices that were formerly the purview of state 
function and have been taken over, for reasons I have discussed above, by other entities, both local and international.

In the case of NGOs in Haiti, they have not replaced the state, but rather I see them as parallel structures that perform certain state functions that have been abandoned because of the state's inability to cater to the needs of its population. I characterize the NGOs in Haiti as a parallel state. Such considerations have political and economic implications. Among these, the most important are related to the reality that: 1) NGOs have more access to international transfer than Haitian state, 2) they provide more services than the state, and 3) they exercise considerable influence over the government.

\section{NGOs Have more Capacity than the State}

The access to international transfers of funds by NGOs in Haiti has increased since the 1990s, when international donors decided to fund them directly, bypassing the government. This trend has continued into the 2000s, persisting after the 2010 earthquake. In 2004, USAID pledged 1.2 billion USD to Haiti, the vast majority of which was disbursed through NGOs (Hallward, 2007). At the International Donors' Conference after the earthquake donors pledged $\$ 5.3$ billion USD to Haiti to be disbursed in two years; -- only one percent of the fund was channeled through the national government (Klarreich and Polman, 2010).

NGOs Provide more Services than the State

Due to the large sum of money at their disposal, NGOs provide services that would otherwise be provided by the state. Before the 2010 earthquake, 72 percent of Haiti's basic 
health care services were delivered by NGOs. They also provided eighty percent of primary education, sanitation, and water provision (Hallward, 2007; International Crisis Group, 2009; Zanotti, 2010). NGOs also operate in agricultural, infrastructural, and housing sectors. Finally, NGOs are reaching out to people in remote areas of the country where there is no governmental presence at all. In those areas, they engage through community organizations and act in a state-like manner.

The national government is complicit in this reality. It serves the political and economic interests of the governing elite benefiting from NGOs and supports their role in the production of state effects. The national government is relieved from the burden of catering to the needs of the population. This same argument can also be made for remittances. All governments in Haiti have been able to mobilize the country's overseas communities to send remittances. These exceed foreign exchange earnings from Direct Foreign investments, foreign aid and grants, and export earnings. Members of the diaspora organize themselves to help their communities and intervene where the national government failed to. And the national government has simply adapted to this reality.

\section{NGOs Exercise Considerable Influence over the Government}

With budgets bigger than those of the government, NGOs exercise considerable influence over the government. Following the earthquake, with billions of dollars of reconstruction aid, NGOs constructed a powerful structure of operations and intervention. Many government projects have been oriented and financed by NGOs. They decide what their priorities are, and the domain and length of their intervention. They self-evaluate their 
projects, and decide for themselves how, where and when to allocate funding. They are also accountable to donors who have the ability to withdraw their funding and investments.

The stage was set even before the earthquake. Francois Pierre-Louis (2011) in his article Earthquakes, Nongovernmental Organizations, and Governance in Haiti, reports that even before the earthquake for every ministry there was a parallel NGO that executed programs and projects. Decisions are often made on the type of projects to finance without the Haitian government's knowledge and consent. Pierre-Louis indicates (2012) that in 2017, USAID, for example, one of Haiti's biggest donors, distributed funds directly to NGOs and assigned specific NGOs to specific ministries to execute specific projects5.

There is a case to be made that NGOs also have a vested interest in catering to the needs of its own officials and institutional needs. It also contributes to the production and reproduction of a domestic elite. It provides the latter with significantly more prestige, income, and authority than working for the government. It exercises influence and power, grants access to visas, and offers opportunities to travel and to participate in relevant meetings in diverse countries. NGOs' offices are better equipped than governmental offices. Their employees work in spaces similar to those in the Western industrialized metropolis. They enjoy all the amenities, including air-conditioning, computers, and Internet access. NGO officials often have chauffeurs, drive nicer vehicles, and earn better salaries than their government counterparts. NGOs hire the most educated people in the country, and those well-paid employees represent what Mark Schuller (2007, 2012) calls

5 For more information see a list distribution of USAID funding to NGOs working in Haiti in 2007, with the type of the projects and the parallel government ministries they work with, and the amount of funding that they received (Pierre-Louis, 2012, pp. 194-95). 
the "NGOs class," a group of high-income earners who are benefiting from privileges that are not accessible to the majority of the Haitian population. This class comprises not only Haitians but also international workers and organizational officials from countries in which they are headquartered or where their donors are located. They live in upscale lives in large modern houses in wealthy areas of Haiti. This is because they are donor-dependent (Pierre Louis, 2012) upon funders integrally tied to the U.S., Canada, and Union European economies to which their job security is tied. The interests of the countries in which they are located are not necessarily paramount. Furthermore, they form an integral part of the neoliberal agenda and its imperatives. This may explain, partly, why NGO projects often address the symptoms of problems instead of the structures that produce them. They may have a vested interest in their perpetuation.

\section{Summary}

In this chapter I, critically examined the political and economic factors that contribute to Haiti's heavy reliance on NGOs. Among those factors, I highlighted the neoliberal policies implemented in Haiti during the 1980s and the 1990s. I argued that neoliberalism disrupted an economy that was based on domestic production and local public and private ownership. The result was depeasantization as well as foreign ownership and control through policies of liberalization. The latter reduced state capacities and capabilities, which led to dependence on NGOs to perform functions that were previously assumed by the national government. This was in keeping with global processes linked to transnationalization. Haiti was particularly and especially vulnerable because of the influence of external actors even before the implementation of neoliberalism. It was also rendered vulnerable because 
of a history of corrupt governance that catered almost exclusively to the interests of an upper strata linked to Western and particularly, American capitalist interests. 


\section{Chapter Four: Haiti Before the Earthquake: The Vulnerability to Disaster}

There are structural factors related to conditions of postcolonial governance and Haiti's color and class-based stratification order that have contributed to the country's vulnerability to disasters and its relative and differential capacities for resilience. The January 2010 earthquake was a human-made disaster. It stemmed from the consequences of politico-economic choices that were made decades before. It also resulted from the ineptitude of a political system that robbed (and has continued to rob) the vast majority of the Haitian population of development and progress. The calamities that the country has experienced as a result of the earthquake in 2010 and have become a focus of world attention, are simply epiphenomena of deeper underlying issues. The theoretical framework that I employ to analyze these issues combine a critical understanding of Percy Hintzen's work on the costs of regime survival with an awareness of the tension between the state and the nation from the perspective of Michel-Rolph Trouillot's Haiti: The State Against the Nation.

\section{The Cost of Regime Survival}

In his seminal work, The Cost of Regime Survival: Racial Mobilization, Elite Domination and the Control of the State in Guyana and Trinidad, Percy Hintzen (1998) critically investigates the conflict that political leaders in underdeveloped countries are facing between sacrificing the collective needs of the society and serving the interests of the elites. The book focuses particularly on Guyana and Trinidad, both countries that obtained their independence during the second half of the 20th century. In the book, Hintzen laid out three 
fundamental needs that a post-independence regime may face if they are to survive: 1) the need to satisfy or neutralize powerful local and international actors, 2) the need to demobilize and co-opt the organized opposition, and 3) the need to retain mass support and prevent outbidding (Hintzen 1998, p. 9-10).

To meet those conditions, Hintzen points out five strategies that political leaders in the less developed countries often utilize:

1) Ideology. According to Hintzen, ideology - particularly what he called 'practical ideology' - refers to socio-political programs that political leaders organize to communicate with both local and international actors. Ideology can vacillate when it is necessary for leaders to gain and maintain control of resources from local international actors. Political leaders or statesmen can also change ideology in the face of new demands as these relate to changes in domestic and international landscape, specifically when those changes are more likely to threaten their power.

2) Patronage. This refers to the distribution of state resources in exchange for political support. Through patronage political leaders develop clientelistic ties with elites in exchange for their support. Patronage can also be used to gain mass support or control members of the military and security forces or even political leaders from the opposition.

3) Control. To expand activities under the domain of the state bureaucracy, political leaders use control. Control, in this context, is employed to deprive political opponents of their resources. Control can be maintained, for example, through nationalization of the economy, deactivation and infiltration of trade union organizations, swaying the legislative process to support the government, placing 
political agents in key positions in the administration, centralizing the state bureaucracy etc.

4) Coercion. It refers to the utilization of the state apparatus against political opponents, dissident groups, or any segments of the population that intend to engage in activities against the government. Coercion, according to Hintzen (1998) proved to be the most effective and efficient strategy that political regimes utilize for their survival.

5) International Realignment. As regimes in less developed countries face local and national threats, they also face international threats that can jeopardize their survival. When facing international threats, regimes can often seek alternative suppliers for resources that are essential to their survival. Those resources include material resources as well as military resources to guarantee their defense against powerful countries (Hintzen, 1998, pp 10-12).

While Hintzen's Cost of Regime Survival was a case study of Guyana and Trinidad, it also may be applied to the case of Haiti.

\section{The State Against the Nation}

The term "state against the nation" was framed by Michel-Rolph Trouillot in his book, Haiti: State Against the Nation and the Legacy of Duvalierism. The term serves to highlight the extreme disjuncture between the state and the nation under the regime of Duvalier in Haiti. In his argument, Trouillot rejected the mainstream conception of the nation as a cultural construct that offers some claim to homogeneity in relation to political power" 
(Trouillot, p. 25). Investigating the case of Haiti, he argued that there has always been a structural division between the black creole-speaking population - (peasantry that constituted the nation,)- and the upper strata who controlled governance (who were French speaking and depended upon global interests).

During the 19th century, the Haitian nation was divided into two groups: the peasantry and the urbanites. The peasantry, although representing the majority of the population, was considered peyi andeyo6, or part of "something outside the country." The peasants were called moun andeyo, or "people outside" (Trouillot, 1990). The urbanites represented mostly the urban population of Port-au-Prince, dominated by a Frenchspeaking elite. The urbanites comprised the following groups:

1) The upper class, mostly mulattoes and light-skinned individuals. They were predominantly businessmen and landowners.

2) The petite bourgeoisie and the upper-middle class. Part of this group were educated black elite professionals, bureaucrats of public sectors, high ranking military officers etc.

3) The middle class and lower-middle class - They were mostly small business owners, primary and secondary school teachers, skilled workers, and soldiers. Trouillot (1990) identified them as a parasite group that depended on the public sector for a job. Without the state, the middle class could not reproduce themselves.

4) Finally, the lower class, composed of artisans, day laborers, small vendors, maids and servants etc. (Pierre-Charles, 1973; Trouillot, 1990).

6 The French word is pays en dehors. 
The social and spatial division between the two factions of the country, the rural and the urban or the peasants and the urbanites, had cultural, economic, and political implications. The peasants were mostly illiterate and they did not speak French --the official language at that time -- the language of the elites. Thus, the urbanites used language to culturally and politically isolate the peasants, and to exclude them from the political process even while maintaining a necessary symbiotic economic relationship. The peasants brought their goods to urban markets, and they brought back to their villages necessities that were not available in the hinterland. These economic transfers between the peasants and the urbanites continued for most of the 20th century (Trouillot, 1990). Through those transfers, the state extracted surplus revenues from the peasantry through taxes that they were forced to pay.

Trouillot explained that both the peasants and the urbanites were conscious of the split between them. As he put:

The Haitian expression moun andeyo (literally, "people outside") that urbanites use to describe the peasantry is as telling as the l'arrière-pays ["the hinterland"]. It signifies both an acknowledgment and an implicit approval of the split. Few urbanites ever wondered how a majority of the nation could be seen as being “outside." Peasants in turn often refer to powerful individuals, especially urbanites, as leta ("the state"), regardless of their actual ties to the state apparatus. In short, both sides acknowledge that a split exists (Trouillot, 1990; p.81).

The peasants were poor and illiterate. The 1950s census reported that 89.5 percent of the population was illiterate (Pierre-Charles, 1973, p. 34), many of whom were peasants. The functioning of the urban strata largely depended on the surplus extracted from the peasantry 
and through taxes. The U.S. occupation of Haiti during 1915 and 1934 reinforced the split between the state and the nation. It did so by worsening the socioeconomic contradictions between the peasantry and the urbanites, and consequently contributed to greater marginalization of the peasantry. Proponents of the occupation often point to the infrastructural improvements that the country had undergone during that time (Ferguson, 1987). In fact, much infrastructural improvements were made while it was in effect. But those improvements reinforced a more centralized system. During the occupation, Port-auPrince became the center of almost everything. Government administration offices, hospitals, schools, and new infrastructures were concentrated in Port-au-Prince (Charles, 2002; Ferguson, 1987; Trouillot, 1990). The peasantry gained nearly nothing from the infrastructural improvements undertaken during the occupation (Ferguson, 1987).

The U.S. Occupation also reinforced the disjuncture between the state and the nation through a process of "whitening" the state apparatus. Color prejudices that existed before the occupation were aggravated. Mulattoes or light-skinned Haitians from the elite classes were placed in positions of authority, for the most part apart from the very few dark-skinned Haitians who occupied important positions in the ministries and army (Trouillot, 1990).

It is important also to note that during the occupation a heavy tax burden was placed on the peasantry particularly through the export of coffee. During this time, coffee became the most important export commodity in Haiti. It accounted for 74 percent of all exports. By the end of the occupation, customs duties represented more than 80 percent of government revenue (Trouillot, 1990, p.103). Those figures inform us of the extent to which the peasantry was being extracted during the occupation. 
However, it was under the Duvaliers (Papa Doc and Baby Doc) that the disjuncture between the state and the nation (the political and the civil society) became exacerbated. Francois Duvalier was a dark-skinned politician. Along with Jean Price Mars, Jacques Roumain, and other Haitian intellectuals he was an advocate of the cultural and political philosophy of négritude that advocated for the rehabilitation of the Black race in the Caribbean and francophone Africa (Charles, 2020). His version of négritude came to be known as noirisme that promoted black middle-class power.

Duvalier was a physician who had a history of working with the peasantry. He was known for treating the poor in rural areas and fighting against the spread of infectious diseases. The peasants loved him and passionately called him Papa Doc (Haggerty, 1991). In 1946, he was appointed General Director of Public Health in Haiti. He rose from that position to become president of Haiti in 1957, and in April 1964, declared himself President for life with the right to nominate his successor. He remained in power until his death on April 21st, 1971. He was succeeded by his son, Jean Claude Duvalier, who became known as "Baby Doc" assuring the continuity of the regime.

In analyzing the Duvalierist regime, (both Papa Doc's and Baby Doc's), Trouillot points to three of its characteristics: extreme violence, incompetence, and corruption. While Haiti has had a long history of state violence and dictatorship under Papa Doc Duvalier, it became notably and qualitatively distinct from that of previous dictators. In the process Duvalier amplified the most despotic facets of the Haitian authoritarian practices (Fatton, 2013, Pierre-Charles; 1973; Trouillot, 1987).

Trouillot argued that the Duvalierist regimes' use of violence appeared to be limitless, total, omnipresent, and irrational (Trouillot, 1990; p.169). It was deployed 
indiscriminately against everyone, irrespective of position, or group, or politics. Gérard Pierre Charles, an eminent Haitian intellectual and politician, in his book Radiographie d'Une Dictature (Radiography of a Dictatorship) characterized the violence deployed by both of the Duvaliers as unlimited and unique in the history of the country (Pierre-Charles; 1973; p.46).

The second characteristic of Duvalierist rule was incompetence. Trouillot (1990) described the Duvalierist regime as "the reign of incompetency, where all power lay with mediocre individuals" (p.173). Indeed, because of the extreme violence imposed by the Duvaliers, many educated Haitians were forced to leave the country. It was a political strategy to govern with only incompetents in order to ensure loyalty as well as to distribute patronage. Incompetent bureaucrat tend to lean more toward loyalty and faithfulness to those in power. The effect of this form of governing is inefficiency (Hintzen, 1998).

Perhaps people accommodated themselves to the violence and incompetence through compliance (Mbebe, 2000), as the regime created deep-seated mistrust and fear within Haiti's population. Agents of the regime were located everywhere and were employed to report any hint of disloyalty and opposition even of their superiors.

The final characteristic that Trouillot described as a condition of power under Duvalier and his son is corruption. Under the Duvalierist state, corruption reached an unprecedented level. It became rife as a practice that spanned from the president to lowranking public officials. Jean Claude Duvalier, for example, was known for his lavish lifestyle; his wedding to a mulatto member of the Haitian elite, Michèle Bennett in 1980 was estimated to have cost 3 million USD (Haiti Observer, 2013). In the final three years before his oust from power, documents from Haiti's Central Bank showed that he had 
embezzled more than 120 million USD from the government. As a political tactic, the Duvaliers put into place a system of clientelism that exchanged favor and office for loyalty. This provided extended opportunities for embezzlement as the regime's supporters were able to enrich themselves in exchange for their loyalty. Trouillot wrote:

Corruption became the very foundation of the administrative machine, its raison d'être. One entered the state apparatus only to benefit from it, for there was no pretense about doing anything else. Corruption became politically effective as never before, it guaranteed the unconditional endorsement of the regime's supporters. (Trouillot, 1990; p.176).

The peasantry was particularly victim to Duvalier regime notwithstanding their almost absolute support that propelled Francois Duvalier's rise to power. They were not exempt, from his cruelty, brutality, and suffered -- mostly - from the inefficiency of the regime. The Duvaliers failed to improve their material conditions and denied them access to political rights (Fatton, 2013). The survival of the regime came to be "more easily maintained through extreme centralization" than through the projects that benefitted the rural peasantry in which negligible investments were made (Trouillot, 1990, p. 176). The peasants remained illiterate, poor, and neglected by the state. They continued to be treated as moun andeyo (outside people), without the full rights of Haitian citizens (Fatton, 2013). In this manner, the civil society - became totally excluded from the political process. Forces of the nation were mobilized to ensure regime survival and guarantee that the interests of the state were realized. To ensure regime survival a paramilitary force called the Tonton Makout, was organized as a militia to terrorize the population and maintain compliance. 
My argument thus far is that violence, incompetence, and corruption were rampant under the regime of the Duvaliers. Their effects on the nation were destructive. They were consistent with the conditions for regime survival employed in most of the Caribbean and Latin American countries as described by Hintzen (1998; 2018). They foreclosed any possibility for the national government to implement the conditions necessary for development and economic progress.

Duvalierist regimes maintained order in the country, but at a high cost -- the cost of survival, through a reinforcing of an ideology, patronage, effective measures control, coercion, and international realignment. The two Duvalier regimes also came to depend on relations with the United States in its strategy for survival. They were able to remain in power for almost thirty years. In this regard, the regime of the two Duvaliers resembled that of the American occupation which was also embedded in forms of control and coercion supported by a foreign military force.

The fall of Jean Claude Duvalier came about because of a rupture in the conditions that guaranteed the regimes' survival produced by a complete break with the ideology of noirisme that held particularly Papa Doc in power, and that advocated for the rehabilitation of the black middle-class and the creation of a black bourgeoisie. Through such ideology, the state under Papa Doc was able to mobilize the symbolic power of its identification with the black creole- speaking nation, and to speak on their behalf. When Jean Claude Duvalier came to power in 1971, he undermined the symbolic capital of his father by aligning with the colored elite through his marriage with Michèle Benett, a mulatto woman. The power of the noiriste ideology began to fade away and the state was no longer able to maintain the narrative as representative of the nation. As a result, the regime lost its ability to 
discipline, regulate, coopt, and control the population, leading to its loss of power. The fall of Duvalier did not, however, change the material or political conditions in the country. Instead, since 1986, Haiti has sunk more deeply into political instability.

There have always been periods, however, where coercion, control, co-optation, and surveillance failed, and where mobilization of the nation began to challenge state interests. These were the circumstances that brought Duvalier to power. It was also the condition that brought a radical Roman Catholic priest called Jean Bertrand Aristide to power with the popular support of the "nation" pitted against the state and its international allies. Aristide was elected to power because of his Lavalas movement. Lavalas is the creole word for avalanche. The Lavalas is a movement that promised a sweeping eradication of social and economic inequalities and the resurrection of popular masses. The movement articulated rhetoric against both national and international elites and rendered them responsible for the misery and the poverty of the masses. The movement was undermined by the state effects of national and global forces. Those forces overthrew Aristide through a coup d'état on September 29th, 1991. Because of intense popular mobilizations both nationally and internationally, Aristide was brought to power after three years in exile but only under the conditions of the application of neoliberal policy, which compromised the nature of the Lavalas movement and Aristide's government's policies.

There has always been tension between the governing apparatus of the state and the people. How this tension is generally managed is what Antonio Gramsci analyzed in his theorization of hegemony, a term that refers to the ways in which a ruling class gains consent to rule from those it subjugates (Eagleton,1991). Analyzing the capitalist state, Gramsci identified two spheres that constitute the capitalist state: a political society and a 
civil society. The latter refers to the public sphere where ideas and beliefs are shaped, reproduced, and legitimized (Heywood, 1994). Legitimacy, here, is gained through consent rather than force. Consent is manufactured through the control of the superstructure including education, religion, and cultural norms.

A counter hegemony that challenges the power of the ruling group can emerge from civil society that contests the dominant class's rules, norms, ideas, and legitimacy, and articulates novel visions and ideas for the transformation of society. Political crises that challenge the ruling group are produced out of a crisis of hegemony itself. This can occur when the dominant class (the state) fails to articulate a vision of development that includes the subaltern groups, (the nation) and conditions for regime survival are no longer effective. These are the conditions that Haiti has been experiencing for a considerable period especially since 1986.

So far, I have argued that the Haitian popular class, organized into the nation, has been engaged in a continuous struggle against the governing apparatus of the state. This struggle intensified between 1986 and 2010. The administrations that succeeded Jean Claude Duvalier, with the exception of Jean Bertrand Aristide, have failed to articulate a clear or coherent ideology while the topography of global politics began to erode conditions of control and coercion that facilitated the survival of the Duvalier regimes. The result has been constant political instability in the country.

Political violence and instability have always been a pervasive feature of Haitian politics since the independence. Throughout the 19th century and before the period of 
American occupation, most of Haiti's presidents gained power through coup d'état7, or following a triumphant insurrection (Pierre-Charles, 1973). Since 1986, the country has witnessed a resurgence of recurring political crises, violence, and rapid governmental changes -- similar to what the country experienced before the American occupation when five presidents gained and lost power. From 1986 to 2010, more than 20 governments8 have come to power in Haiti, with an average tenure just little more than a year per government (see Table 4.1). This is a testament to the current political instability in the country. Between 1986 - 2010, René Préval was the only president to have completed his term of office and to have done so for a second term. He remained in power even under conditions of deterioration in economic performance and his capitulation to neoliberalism. His success can be explained by his ability to build on the ideology of Lavalas that appealed directly to the subaltern nation, his skillful use of patronage for political support, his ability to develop clientelistic ties with the economic elites, and a repositioning of his international alignment. The latter is an essential condition for regime survival, as we have seen with Hintzen $(1998,2018)$. Particularly during his second term, René Préval generated the opposition support and silence through the distribution of political positions and jobs, and also used the resources of the state to distribute patronage to the elites through lucrative contracts.

7 See Haiti and Its Occupation by the United States in 1915: Antecedents and Outcomes, published by Center for Black Studies Research.

8 The Haitian constitution of 1987 makes the prime minister the chief of the government, not the president. The parliament controls the government. If they are not satisfied with the performance of the government, they can give a vote of no-confidence to the prime minister. When the prime minister receives a noconfidence vote, the government changes. A new prime minister will be nominated and ratified by the parliament. The new prime minister, along with the president, will choose new cabinet members. Thus, a president may have more than one government during his term. 
Table 4.1: Haiti's Governments9, 1987-2010

\begin{tabular}{|c|c|c|c|}
\hline $\begin{array}{l}\text { Num- } \\
\text { ber }\end{array}$ & Governments/Administration & Period Served & Time Served \\
\hline 1 & $\begin{array}{l}\text { President: Henri Namphy } \\
\text { (Military junta) }\end{array}$ & $02 / 1986-2 / 1988$ & 2 years \\
\hline 2 & President: Leslie F. Manigat & $02 / 1988-6 / 1988$ & 4 months \\
\hline 3 & $\begin{array}{l}\text { President: Henri Namphy } \\
\text { (Military government) }\end{array}$ & $06 / 1988-09 / 1988$ & 3 months \\
\hline 4 & $\begin{array}{l}\text { President Prosper Avril } \\
\text { (Military government) }\end{array}$ & $09 / 1988-03 / 1990$ & 20 months \\
\hline 5 & $\begin{array}{l}\text { President: Hérard Abraham } \\
\text { (Military government) }\end{array}$ & 0/1990 -3/1990 & 3 days \\
\hline 6 & President: Ertha Pascal-Trouillot & $03 / 1990-02 / 1991$ & 10 months \\
\hline 7 & $\begin{array}{l}\text { President Jean-Bertrand Aristide } \\
\text { Prime Minister : René Préval }\end{array}$ & $\begin{array}{l}02 / 1991-09 / 1991 \& \\
10 / 1994-10 / 1996\end{array}$ & $\begin{array}{l}7 \text { months in Haiti } \\
\text { ( } 2 \text { years in exile) }\end{array}$ \\
\hline 8 & $\begin{array}{l}\text { President: Joseph C. Nerette } \\
\text { Prime Minister : Jean-Jacques } \\
\text { Honorat }\end{array}$ & $\begin{array}{l}10 / 1991-06 / 1992 \\
10 / 1991-02 / 1992\end{array}$ & $\begin{array}{l}7 \text { months } \\
7 \text { months }\end{array}$ \\
\hline 9 & $\begin{array}{l}\text { No de facto president } \\
\text { Prime Minister: Marc Bazin }\end{array}$ & $06 / 1992$ to $06 / 1993$ & 12 months \\
\hline 10 & $\begin{array}{l}\text { President: Emile Jonassaint } \\
\text { No Prime Minister }\end{array}$ & $06 / 1993$ to $09 / 1994$ & 3 months \\
\hline
\end{tabular}

9 From 1986 (the year of the fall of Jean Claude Duvalier) to 1996, Haiti has known 10 presidents. The period of 1997 to 2010 appeared to be more stable, with five presidents succeeded during the period. This is due to the fact that René Préval, who became president twice during this period, was able to complete both terms. Rene Préval was the only president since the fall of Duvalier in 1996 to the date of the earthquake who concluded his term as president. 


\begin{tabular}{|c|c|c|c|}
\hline 11 & $\begin{array}{l}\text { President: Jean-Bertand Aristide } \\
\text { Prime Ministers: } \\
\text { (3) Smark Michel } \\
\text { (4) Claudette Werleigh }\end{array}$ & $\begin{array}{l}10 / 1994 \text { to } 02 / 1996 \\
11 / 1994 \text { to } 10 / 1995 \\
10 / 1995 \text { to } 02 / 1996\end{array}$ & $\begin{array}{l}16 \text { months } \\
11 \text { months } \\
5 \text { months }\end{array}$ \\
\hline 12 & $\begin{array}{l}\text { President: René Préval } \\
\text { Prime Ministers: } \\
\text { (1) Rosny Smart } \\
\quad \text { (2) Jacques Edouard Alexis } \\
\text { No Prime Minister since }\end{array}$ & $\begin{array}{l}02 / 1996-02 / 2001 \\
05 / 1996 \text { to } 06 / 1997 \\
03 / 1999 \text { to } 02 / 2001 \\
06 / 1997 \text { to } 03 / 1999\end{array}$ & $\begin{array}{l}5 \text { years } \\
14 \text { months } \\
23 \text { months } \\
-\end{array}$ \\
\hline 13 & $\begin{array}{l}\text { President Jean Bertrand Aristide } \\
\text { Prime Ministers: } \\
\text { (1) Jean Marie Chérestal } \\
\text { (2) Yvon Neptune }\end{array}$ & $\begin{array}{l}02 / 2001 \text { to } 02 / 2004 \\
02 / 2001 \text { to } 01 / 2002 \\
03 / 2002 \text { to } 02 / 2004\end{array}$ & $\begin{array}{l}3 \text { years } \\
11 \text { months } \\
23 \text { months }\end{array}$ \\
\hline 14 & $\begin{array}{l}\text { President: Boniface Alexandre } \\
\text { Prime Minister: Gerard Latortue }\end{array}$ & $\begin{array}{l}02 / 2004 \text { to } 05 / 2006 \\
03 / 2004 \text { to } 06 / 2006\end{array}$ & $\begin{array}{l}27 \text { months } \\
27 \text { months }\end{array}$ \\
\hline 15 & $\begin{array}{l}\text { President René Préval } \\
\text { Prime Ministers: } \\
\text { (1) Jacques Edouard Alexis } \\
\text { (2) Prime Minister: Michelle } \\
\text { Pierre Louis } \\
\text { (3) Jean-Max Bellerive }\end{array}$ & $\begin{array}{l}05 / 14 / 2006 \text { to } \\
05 / 14 / 2011 \\
06 / 2006 \text { to } 04 / 2008 \\
09 / 2008 \text { to } 11 / 2009 \\
11 / 2009 \text { to } 10 / 2011\end{array}$ & $\begin{array}{l}5 \text { years } \\
22 \text { months } \\
14 \text { months } \\
23 \text { months }\end{array}$ \\
\hline
\end{tabular}

These rapid changes in government point to the instability produced by the fracture between the state and nation, with the latter now incorporating the urban migrants from the peasantry as an underclass. Trouillot's peasantry in today's Haiti has collapsed over the last four decades. The new divide is produced out of a disjuncture between what Fatton (2007) calls the "possessing class" and subaltern groups. The rapid changes in government are produced out of such a disjuncture and the inability of the elite to maintain control of 
the state and its resources. Such a disjuncture articulates the limits of the Haitian state to be an instrument of genuine development and to create the conditions for effective democracy (Hintzen, 2018).

The Haitian state has become a predatory state (Dupuy, 1997, 2005; Fatton, 2002; 2008; Meehan, 2004). Predation, in this way, has become a condition for holding power. Similar observations have also been made in West Indian states in the region. In his article, Towards a New Democracy in the Caribbean: Local Empowerment and the New Global Order, Percy Hintzen (2018) has argued that depriving the subalterns of access to effective participation in governance and economic processes has allowed the middle class and upper strata to use illegal means and pervasive practices of corruption in order to gain and maintain state control. In turn, the masses respond to such conditions by developing their own political practices and social and economic agency. Hintzen (2018) writes:

The lower strata, as the overwhelming majority, by and large are without these opportunities, except indirectly through forms of patronage and clientelism. They are forced to create their own conditions for economic opportunity, their own extrajudicial forms of political practice (including riots), and their own forms of social welfare and protective security. For them, the 'societal arrangements', formed and fashioned to satisfy social needs through the guarantee of economic and political rights occur outside governing practice (p.98).

The way state power has been gained, constituted, and maintained encapsulates the structural and historical conditions that produce precarity within the masses, the majority of the population. It also produces the profound vulnerabilities that we noticed on January $12,2010$. 


\section{Weak Economy, Structural Poverty, and Vulnerable Population}

There were profound vulnerabilities in Haiti that produced forms of extreme precarity prior to the earthquake. During the two decades preceding the earthquake, Haiti's economic growth had been declining, while poverty and income inequality were rising (World Bank, 2007; 2015). During the 1990s and 2000s, the average GDP growth was below one percent, which was much lower than the 3.5 percent average growth of Latin American Countries (Singh, 2015, p. 43). The country experienced some short-lived positive growth in the years following 1994, when President Aristide, who was ousted from power after seven months in office. He was reinstated by the United States after agreeing to the neoliberal agenda. The initial growth was immediately followed by five subsequent years of negative growth (Singh and Barton-Dock, 2015, p.43) that continued to contribute to massive urban migration and susceptibility to natural disasters (Table 4.2), under conditions of dramatically increased vulnerability for the population.

The country maintained its position in the low human development category in UNDP's Human Development rankings. Out of 189 countries and territories, Haiti was positioned at 168 in these rankings (UNDP, 2019). Particularly, during the two years before the earthquake, the social and economic conditions in Haiti were worsening. More than 3.3 million Haitians were threatened by food insecurity, which caused food riots to erupt in diverse regions of the country (International Crisis Group, 2009). The worsening of the economic situation was partly due to four tropical storms and hurricanes that hit the country during August and September of 2008 (International Crisis Group, 2009; Singh and Barton-

Dock, 2015). Eight hundred people were killed, one million were affected, and widespread 
damage affected the country's already- minimal infrastructure, which exacerbated the food shortage (ALNAP, 2010; International Crisis Group, 2009; Rencoret, 2010) 10.

Table 4.2: Summary of the Last three Disasters in Haiti Before the 2010 Earthquake11

\begin{tabular}{|l|l|l|l|l|}
\hline Year & Events & Effect on GDP & $\begin{array}{l}\text { Individuals } \\
\text { Affected }\end{array}$ & Dead \\
\hline 2004 & Hurricane Jeanne & $7 \%$ of GDP & 300,000 & 5,000 \\
\hline 2007 & Hurricanes Dean and Noel & $2 \%$ of GDP & 194,000 & 330 \\
\hline 2008 & $\begin{array}{l}\text { Hurricanes Fay, Gustav, } \\
\text { Hanna and Ike }\end{array}$ & $15 \%$ of GDP & $1,000,000$ & 800 \\
\hline Total & N/A & $24 \%$ of GDP & $1,494,000$ & 6,130 \\
\hline Source: Republic of Haiti, Post-Disaster Needs Assessment (PDNA) 2010
\end{tabular}

In 2008 , the economy grew only slightly by 1.3 percent against an inflation rate of 13 percent resulting in a real growth rate that was negative. During the same year, nearly three-quarters of the population was living below \$2 a day (World Bank, 2009a; International Crisis Group, 2009). In 2009, 50.6 percent of the population was living in urban areas, but 83 percent of them resided in slums under conditions of a high-density and significant health concerns. Only 30 percent of the population had access to some form of public health, while 70 percent of the population had no access to healthcare at all (ALNAP, 2010). There was also a reduction in remittances, during the period as a result of the global recession and the economic crisis in the United States. This rendered the

10 According to the international Crisis Group (2009), before the earthquake Haiti was on the verge of economic progress. The country was politically stable. There was also a huge relief effort to help the country following the four disasters that hit the country in 2008.

11 These figures are published in Rencoret et al (2010). Haiti Earthquake: Context Analysis, p. 14. They are modified for the purpose of this research. 
conditions even more dire and precarious. Transfers to Haiti from remittances dropped by 15 percent (Haiti Libre, 2013). It was in the face of these deplorable social and economic conditions and profound vulnerability that the earthquake hit Haiti on January 12, 2010.

\section{Summary}

This chapter draws heavily on both Hinzen's scholarship on the Costs of Regime Survival and Trouillot's State Against Nation in order to examine the conditions by which state power is gained, constituted, and reproduced in Haiti -- conditions that include control, coercion, and violence. Although these conditions are not unique to Haiti, I have shown that they played an immense and determinative role in Haiti since the independence of the country and have intensified since 1986. I argued that the way state power has been constituted and its effects have created the historical conditions that produce precarity among the vast majority of the Haitian population, the subaltern.

I also argued that there have been times when strategies for regime survival are no longer effective, when regimentation, regulation, control, surveillance, and coercion are no longer working; this was what precipitated the fall of Duvalier. When such conditions occur, opportunities arise for a new kind of discourse. These can provide possibilities for the emergence of novel strategies capable of altering the conditions that create precarity in the first place, producing true economic development and supporting democracy. These conditions failed to emerge and take root following the fall of the Duvalierist regime. Instead, the state continues to destroy the nation. The dominant class and political elites continue to be beneficiaries of the system to the detriment of the poor. The calamities that 
the country experienced on January 12, 2010 only reflect the degree to which the profound disjuncture between the state and the nation has rendered Haitian governments ineffective, and the extent to which Haiti's vulnerability to disaster has increased as a result of the way the state power is constituted. 


\section{Chapter Five: The Post Disaster Intervention}

Immediately following the earthquake, the international community mobilized a massive support effort to help the devastated country. Individuals around the world, Haitians in the diaspora, international governments, UN agencies, and NGOs were all involved in the effort. In particular, there was an enormous influx of NGOs, adding to the thousands that were already in the country before the earthquake. Many came from the United States, perhaps because of the history of U.S. based NGO presence in the country, as well as its bi-lateral funding, notably from USAID. The Haitian government was clearly overwhelmed. Its ability to cope was made even more difficult in the wake of the loss of essential government personnel. No government ministers died, but numerous human losses occurred in the administrative apparatus. Many public servants spent the first few days after the earthquake trying to locate and care for their loved ones (Grünewald and Renaudin, 2010).

Material damages in the public administration were also enormous. According to the Haitian government 13 of 15 government ministry buildings were collapsed, the majority of the public administration buildings were completely or partially destroyed including the Presidential Palace, the Parliament, and the Palace of Justice (GOH, 2010). Such conditions, in addition to grave damages to the country's transportation, communication, and energy infrastructure, greatly limited the capacity of the administration, thus hindering the government's ability to manage the crisis.

Even before the disaster, the government exercised very limited control over the NGOs. Generally, NGOs benefit from relative autonomy and freedom from state jurisdiction. In Haiti, their autonomy has been even greater due to the ineffectiveness of 
the state. The damages that the government suffered as a result of the earthquake automatically lessened the government's capacity to coordinate the NGOs and aid agencies in the disaster relief efforts.

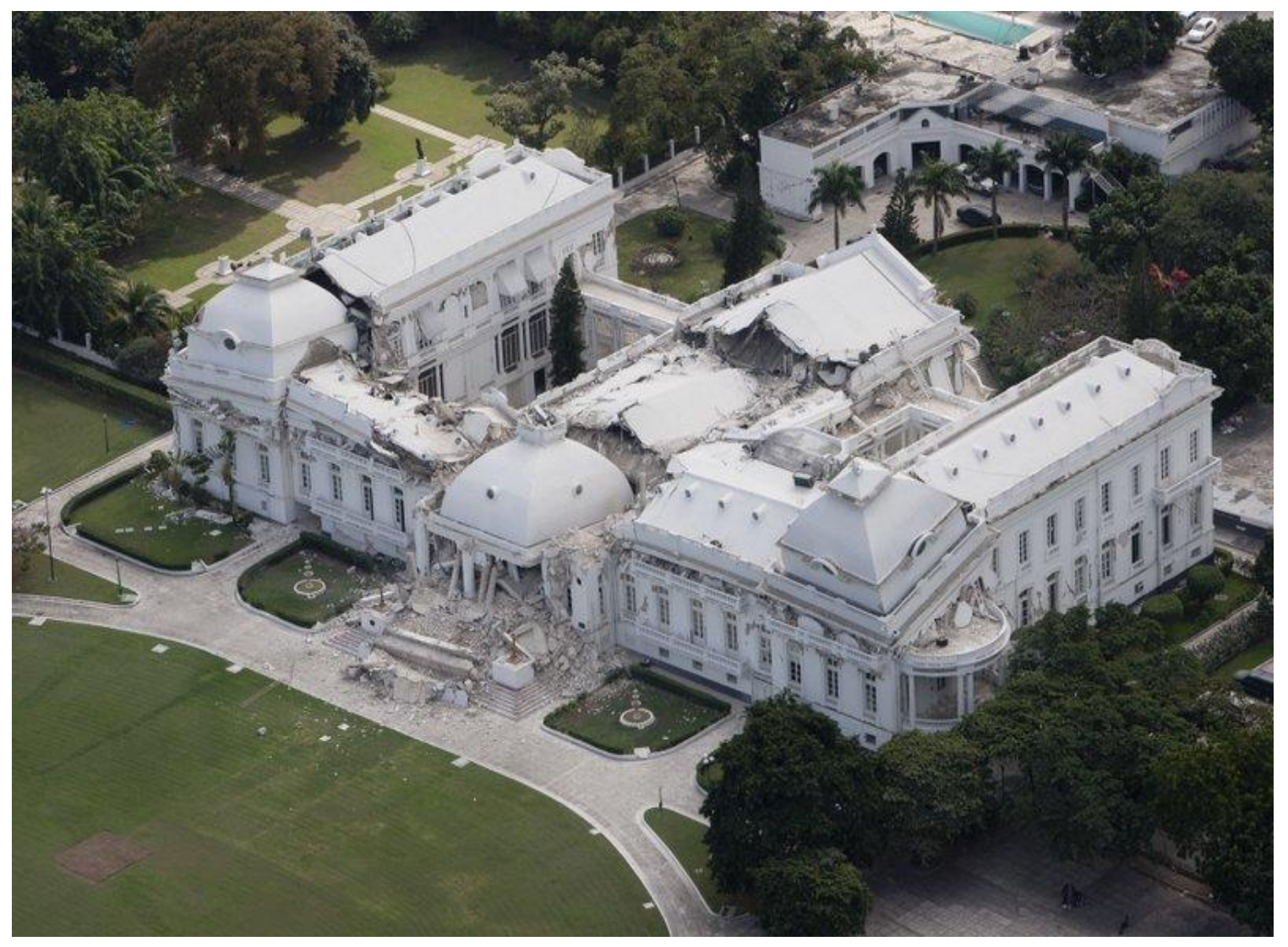

Figure 5.1: The National Palace in Port-au-Prince12.

In the face of government incapacity and ineffectiveness, the UN's Office for the Coordination of Humanitarian Affairs (OCHA) began to coordinate relief efforts. Thus,

12 The capital of Haiti, severely damaged by the earthquake. The National Palace is a 90-year-old structure that was built during the American Occupation in Haiti (1915-1934). (AP Photo/Tyler Anderson). 
assessments of damage and need for material and financial assistance fell to the Humanitarian Country Team (HTC). The HCT was already present and operating in the country following the tropical storms and hurricanes that struck the country in August and September 2008. Those events killed more than 800 Haitians, affected nearly one million, and exacerbated food shortages and poverty in Haiti (International Crisis Group, 2009).

Within three days of the earthquake, Haiti made its first request for money, based on a rapid remote sensing assessment of the damage. The first request for 575 million USD was made on January 15 th, 2010. About a month later, the request was increased to 1.4 billion USD. This would support the need for a full humanitarian intervention, and for resources to cover the activities of 76 aid organizations operative in the country (Rencoret et al., 2010). This amounted to the largest-ever natural disaster request for Haiti (Rencoret et al., 2010, p. 23).

By April 30th, 47 to 55 percent of the revised 1.4 billion USD request was already disbursed (Rencoret et al., 2010). In the wake of the disaster, some countries and funding agencies including -- G7's members (Canada, U.S., U.K., France, Germany, Italy, Japan), the Inter-American Development Bank, and Venezuela -- agreed to forgive Haiti's outstanding debt. Haiti's Caribbean neighbors also mobilized disaster aid, particularly through the Caribbean Catastrophic Risk Insurance Facility (CCRIF), which gave a payout, totaling 7.75 million USD in disaster assistance directly to the Haitian government (Rencoret et al., 2010).

The Haitian government, until that time, was critically involved in the process. It engaged in systematic efforts to get relief funding, secure funding commitments, and produce an Action Plan for National Recovery and Development. In this regard, a series of 
outreach meetings with key constituencies were held in preparation for a planned Donors Conference, to seek feedback on and support for the Government's strategic plan. The meetings were as follows (UN, 2010).

- March 15: Consultation with citizens in Haiti through focus group discussions, called Voice of the Voiceless consultations. (This effort was led by the Office of the Special Envoy and the United Nations in Haiti.)

- March 15: Consultation with Haitian and international private sector representatives hosted by the Inter-American Development Bank in Port-au-Prince.

- March 23: Consultation with Haitian Diaspora hosted by the Organization of American States in Washington D.C.

- March 23: Consultation with local government authorities hosted by France in Saint Martin.

- March 25: Consultation with NGOs hosted by the Office of the Special Envoy, Interaction and the European Union held in New York. NGOs from Haiti, the Americas and Europe participated.

\section{The International Donors Conference}

The most significant funding commitment was coordinated by the UN, at the International Donors Conference, Toward a New Future for Haiti, held in New York on March 31st. There was an important international representation of delegates at the conference. The photograph below signifies the degree of seriousness the international community was 
bringing to the disaster by the presence of some of the world's most important and influential leaders.

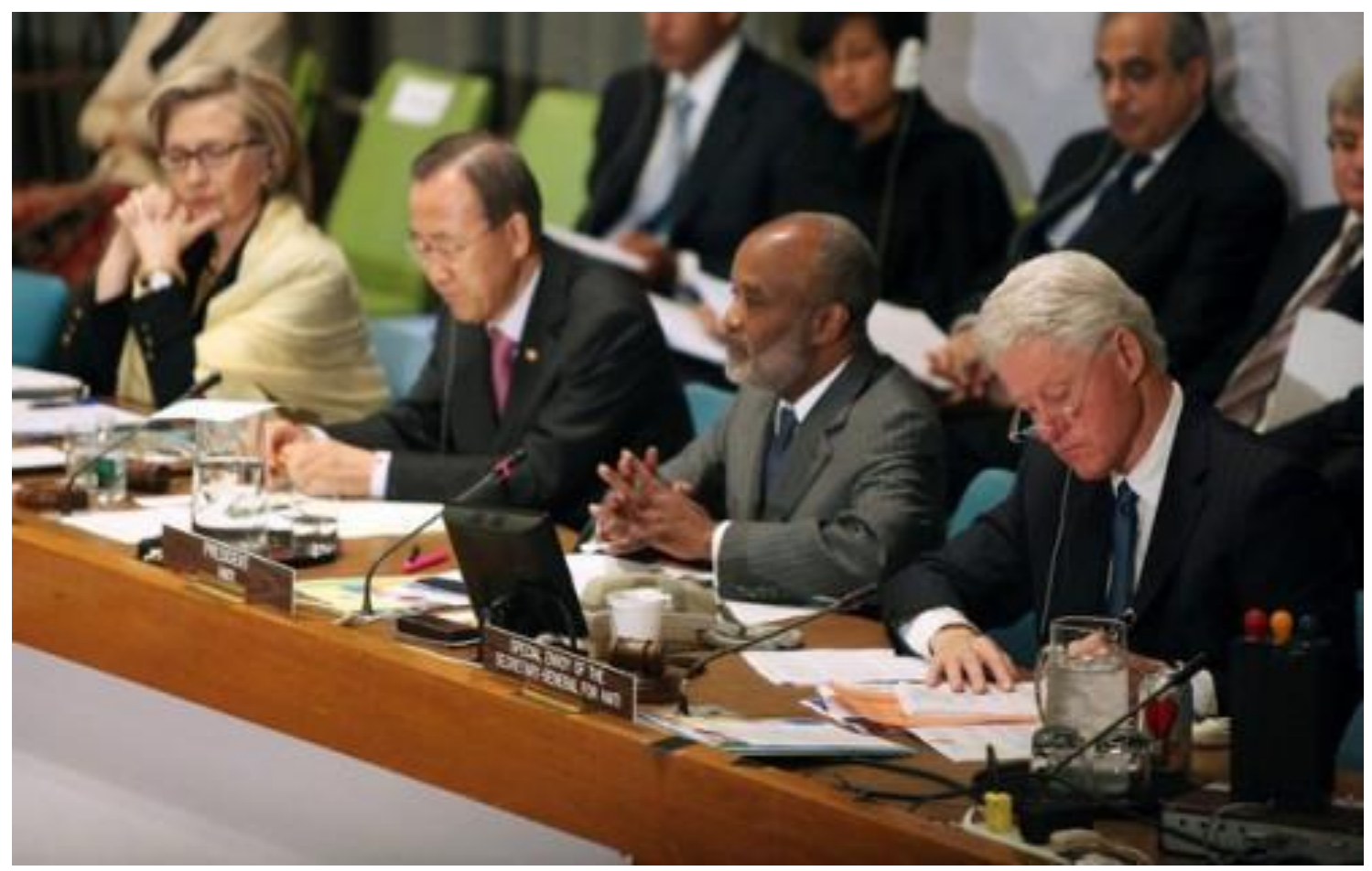

Figure 5.2: International Donors' Conference, Toward a New Future for Haiti.

From left to right sat US Secretary of State Hilary Clinton, U.N Secretary General Ban Ki-moon, Haitian president Rene G. Préval, and former U.S. President Bill J. Clinton. There were also many other important world leaders present at the conference. For example, Robert Zoellick, President of the World Bank; Luis Alberto Moreno, president of the Inter-American Bank of Development; Campton Bourne, representing the Caribbean Development Bank, Percival James Paterson, former prime minister of Jamaica, representing the CARICOM; other world leaders such as Bernard Kouchener, Minister for Foreign Affairs in France; Gerald Tremblay, the mayor of Montreal; Antonio Simoes, 
Brazil Undersecretary for South America and the Caribbean, and representatives of important Civil Society Organization (C-Span, 2010).

At the conference, the president of Haiti, René Préval, shared his hope to rebuild a new Haiti. Jean Max Bellerive, Haiti's Prime Minister, presented the Haitian Government

Monies Raised and Disbursed in Support of Haiti as of December 2012 (Source: Office of the Special Envoy for Haiti, based on donor reporting and publicly available data)

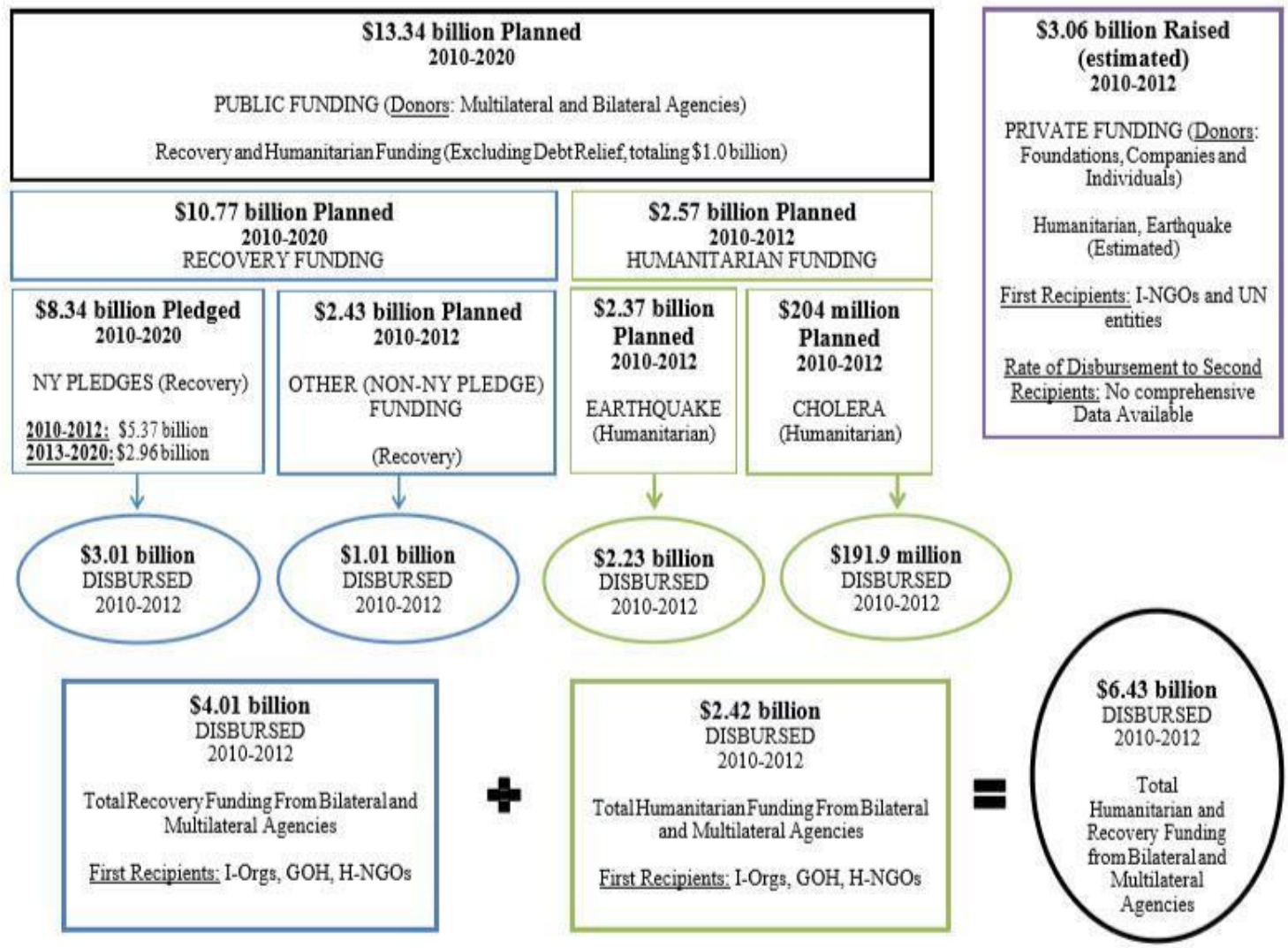

Figure 5.3: Money Raised and Disbursed to Haiti Between 2010- 2012

Action Plan to rebuild the country, a plan that he said "has been formed through a broadbased consultation with the private sector, Non-Governmental Organizations, the Haitian diaspora and the international community" (UN, 2010). 
Donors pledged 9.9 billion USD of funding for the reconstruction and recovery of Haiti. Of this 5.3 billion USD were to be disbursed over two years in support of the Action Plan for National Recovery and Development Plan that the Haitian government designed following the earthquake, based on the results of the Post Disaster Needs Assessment (Rencoret et al., 2010). Within the two years following the earthquake, Haiti received 6.43 billion USD (see Figure 5.3). However, most of this money was not disbursed to the government directly, but channeled to the I-NGOs and NGOs, and other relief agencies.

There are serious disjunctures between commitments expressed at the conference and what was put into practice: First, in the way the money was disbursed and managed; and second, in the development goals envisioned at the conference and the reality on the ground. Before analyzing the disjunctures, we need to look at some remarks made in the conference and the goals that were set. It is particularly important to take a look at what was said by Hilary Clinton and Ban Ki-moon.

\section{International Donors Conference: Towards a New Future for Haiti, March 31, 2010}

Several important statements were made at the conference. For the purpose of this research, it is important, here, to examine and discuss the opening statement 13 of the UN Secretary General, Ban Ki-moon and the remarks 14 of the US Secretary of State, Hillary Clinton.

13 https://www.un.org/press/en/2010/ga10932.doc.htm

14 https://still4hill.com/tag/haiti/ 
The UN Secretary Ban Ki-moon's Opening Statement:

For weeks, experts had been assessing the needs and costs of the 12 January disaster. In tandem President Préval, Prime Minister and their Government had worked out the blueprint for a national strategic plan. A plan to guide Haiti's recovery and reconstruction. He will present that vision in a moment. And I am sure you will agree that it deserves our full and generous support. As a plan for action it is concrete, specific, and above of all, ambitious.

Our goal is not just to rebuild. It is to build back better. Again, to quote the president, it is a plan to create a new Haiti, a Haiti where the majority of people no longer live in deep poverty, where they can go to school and enjoy better health, where they have better options than going without jobs or leaving the country altogether.

Under this plan, a new Interim Haiti Recovery Commission would channel \$3.9 billion into specific programs and projects during the next 18 months. Over the next 10 years, Haiti's reconstruction needs will total an estimated $\$ 11.5$ billion. Clearly, this assistance must be well invested and well-coordinated. In parallel with reconstruction, it must provide for continuing emergency relief, food, sanitation, health care, and most urgently, at this moment, shelter.

You are all aware how difficult is the situation right now. The rainy season is fast approaching. Some camps for displaced persons are at risk of flooding. Health and sanitation issues are growing more serious. We are also very concerned about the security situation in some of the camps, especially for women and children.

I therefore appeal for further support for the Revised Humanitarian Appeal for \$1.4 billion, currently only 50 percent funded. As we move from emergency aid to longterm reconstruction, let us recognize that we cannot accept business as usual. What we envision today, is wholesale national renewal, a sweeping exercise in nationbuilding on a scale and scope not seen in generation.

\section{The US Secretary of State Hilary Clinton's Remark}

...Some people wonder, "Why Haiti? Why this great outpouring of international humanitarian concern and commitment to Haiti's future? Why is Haiti's fate of such consequence to the region and the world that it deserves sustained help? Why should we hope that this time, with our collective assistance, Haiti can achieve a better future?" These are questions that deserve answers and I believe that this conference will begin to do so.

There are two paths that lie before us. If Haiti can build safe homes, its citizens can escape many of the dangers they now face and return to more normal lives. If Haiti can realize broad-based, sustainable economic growth, it can create opportunity across the country beyond Port-au-Prince, so Haitians don't have to move to their capital or leave their country to find work. If Haiti can build strong health and education systems, it can give its people the tools they need to contribute to their nation's progress and fulfill their own God-given potentials. If Haiti can create 
strong, transparent, accountable institutions, it can establish the credibility, trust, and stability its people have long-deserved. And if Haiti can do all of those things with our help, it will become an engine for progress and prosperity generating opportunity and fostering greater stability for itself and for countries throughout the hemisphere and beyond.

But there is another path that Haiti could take, a path that demands far less of Haiti and far less of us. If the effort to rebuild is slow or insufficient, if it is marked by conflict, lack of coordination, or lack of transparency, then the challenges that have plagued Haiti for years could erupt with regional and global consequences. Before the earthquake, migration drained Haiti of many talented citizens, many of whom live in our country. If new jobs and opportunity do not emerge, even more people will leave.

Before the earthquake, hunger was a problem for Haiti. Years of deforestation had stripped the land of its rich topsoil and people struggled to grow or purchase enough food to feed their families. The riots over food that broke out in 2008 toppled Haiti's government. Now, food is even more scarce, and people more desperate.

The leaders of Haiti must take responsibility for their country's reconstruction. They must make the tough decisions that guide a strong, accountable, and transparent recovery. And that is what they are starting to do with the creation of a new mechanism that provides coordination and consultation so aid can be directed where it is most needed. And we in the global community, we must also do things differently. It will be tempting to fall back on old habits - to work around the government rather than to work with them as partners, or to fund a scattered array of well-meaning projects rather than making the deeper, long-term investments that Haiti needs now. We cannot retreat to failed strategies.

I know we've heard these imperatives before - the need to coordinate our aid, hold ourselves accountable, share our knowledge, track results. But now, we cannot just declare our intentions. We have to follow through and put them into practice. Therefore, this is not only a conference about what financially we pledge to Haiti. We also have to pledge our best efforts to do better ourselves - to offer our support in a smarter way, a more effective way that produces real results for the people of Haiti.

In his address, the U.N. Secretary General argued and advocated for the incorporation of sustainable development goals in the rebuilding process. He advocated for a new Haiti, a developed Haiti "where the majority of people no longer live in deep poverty, where they can go to school and enjoy better health, where they have better options than going without jobs or leaving the country altogether." He also announced during the conference the creation of the Interim Haiti Recovery Commission, which would oversee the 
implementation of the Government of Haiti's Action Plan for National Recovery and Development. The commission would also "ensure that the international assistance is aligned with the priorities of the Haitian People and their government, ensuring accountability and transparency" (OSGSA, 2010). The commission was co-chaired by Haiti's Prime Minister Jean Max Bellerive and the former President of the United States Bill Clinton.

Hillary Clinton also advocated for sustainable development. In her statement, she addressed the issues of Haitian migration. She argued that if Haiti realizes "broad-based, sustainable economic growth, it can create opportunity across the country," then there would be no need for Haitians to migrate from rural areas to Port-au-Prince or leave the country. She also highlighted the problems of hunger, environmental degradation, weakness of the state, and the necessity for the international community to do things differently and provide relief in ways that could produce positive results for the people of Haiti.

Thus, both Hilary Clinton and Ban Ki-moon were advocating for sustainable development, effective, efficient, and responsible governance, and resilience to be built into the goals and objectives of disaster relief aid.

Notwithstanding these firm commitments to sustainable development and good governance expressed at the conference, they were not built into disaster relief efforts. The failure to do so is manifested ten years after the earthquake in the failure of recovery efforts. This failure was evidenced in the responses of a survey I conducted to assess the effectiveness of the recovery effort and whether resilience was built into the efforts. I discuss the results of the survey in the next section of this chapter. 


\section{The Resilience Survey: Findings and Analysis}

The objective of the survey was to determine whether the goals of resilience were achieved through self-assessments of recovery by respondents. The survey was conducted in three communes in Port-au-Prince. The city of Port-au-Prince is a large metropolitan area constituted by eight communes: Port-au-Prince (the downtown area, a commune that shares the name with the greater city of Port-au-Prince), Carrefour, Gressier, Cité Soleil, Delmas, Tabarre, Pétion Ville, and Kenscoff. The sample survey was administered to 889 households.

The three surveys were conducted in Delmas, the commune of Port-au-Prince, and the suburb of Carrefour (see Table 4.4). These three communes were chosen to be representative of the greater Port-au-Prince area. Delmas is located on the Northern Side of Port-au-Prince, the commune of Port-au-Prince is in the center, and Carrefour is on the South Side of Port-au-Prince. These three communes were severely damaged by the earthquake. Although the three are part of the greater Port-au-Prince area, they share some socioeconomic characteristics that are important to highlight here. 


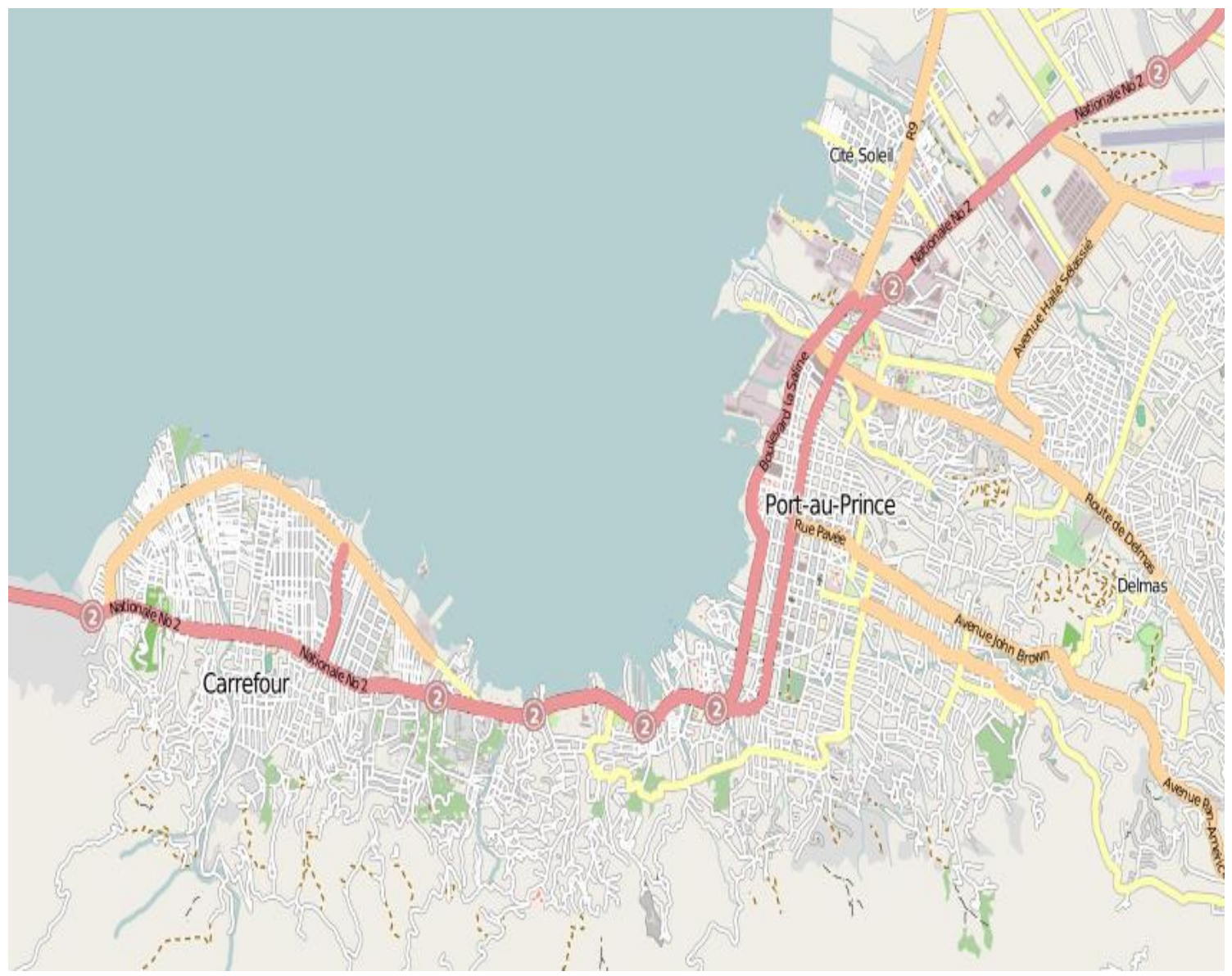

Figure 5.4: Map of Port-au-Prince with the location of the three communes surveyed.

\section{Demography and Social Economic Status}

Table 5.1 below presents the economic and demographic data across the three communes.

\section{The Commune of Port-au-Prince}

The commune of Port-au-Prince is located at the center of the greater Port-au-Prince area. It is largely characterized by its social and economic diversity. It is the largest commercial center of Haiti. The majority of government offices are located in the commune 
Table 5.1: Sample Description by Commune

\begin{tabular}{lcccc}
\hline & & \multicolumn{3}{c}{ Commune } \\
\cline { 3 - 5 } & Total & Delmas & $\begin{array}{c}\text { Port-au- Carrefour } \\
\text { Prince }\end{array}$ \\
\hline Sample size & 889 & 329 & 288 & 272 \\
Household size & 4.68 & 4.85 & 4.65 & 4.49 \\
\% children in household & 29.3 & 25.2 & 30.7 & 32.9 \\
\% working in household & 33.9 & 32.5 & 33.5 & 36.1 \\
Level of education (\%) & & & & \\
$\quad$ No schooling & 5.6 & 3.7 & 5.9 & 7.7 \\
$\quad$ Primary & 23.8 & 17.7 & 23.1 & 32.0 \\
$\quad$ High school & 48.0 & 51.5 & 46.2 & 45.6 \\
$\quad$ Vocational school & 7.8 & 11.6 & 8.7 & 2.2 \\
$\quad$ College or above & 14.8 & 15.5 & 16.1 & 12.5 \\
Work status $(\%)$ & & & & \\
$\quad$ Not employed & 19.3 & 26.8 & 14.0 & 15.8 \\
$\quad$ Employed in informal jobs & 62.0 & 53.4 & 64.3 & 69.9 \\
$\quad$ Employed in formal jobs & 18.7 & 19.8 & 21.7 & 14.3 \\
Neighborhood class (\%) & & & & \\
$\quad$ Working class & 32.3 & 13.7 & 39.2 & 47.4 \\
$\quad$ Middle class & 65.9 & 84.8 & 58.0 & 51.5 \\
$\quad$ Upper class & 1.8 & 1.5 & 2.8 & 1.1 \\
\hline Source 2019 Hait Resilience Survey & $($ Analytic & & &
\end{tabular}

Source: 2019 Haiti Resilience Survey (Analytic

$N=889$ )

Note: Numbers in italics are

percentages

According to Table 5.1, 39 percent of the population in Port-au-Prince identified as working class, while 58 percent identified as middle class. Port-au-Prince has the highest number of people self- identified as upper class, which represents 2.8 percent of its population. It also has the lowest number of unemployed people among the three communes. Only 14 percent of the residents of the commune are unemployed. However, most people in the commune are working in the informal sector. Almost 22 percent hold a formal job, which, among the three communes represents the highest proportion of people formally employed. 


\section{Delmas}

The commune of Delmas is located in the northern part of the capital. It represents the third most populated commune in Port-au-Prince, and in the whole country. It is the location of many industrial and commercial enterprises. It is the wealthiest community in Haiti based on the tax revenue that they collect. Delmas collects more tax revenue than any other commune or suburb in Port-au-Prince.

Delmas is a middle to high income community. About 80 percent of its residents self-reported as having at least a secondary education, compared to 71 percent in Port-auPrince and 60 percent in Carrefour. About 85 percent of Delmas residents consider themselves middle class (Table1). Less than 14 percent consider themselves working class. Only 3.7 percent self-reported as having no education, compared to 5.9 percent in the commune of Port-au-Prince and 7.7 percent in the commune of Carrefour.

Delmas also has better infrastructure compared to the rest of the capital. The population has access to clean water and excellent schools. One of the best private hospitals in the country is in Delmas. Many Haitians in the diaspora who are supporting family members in Port-au-Prince often choose Delmas for their parents or family members' residences because of the modern urban infrastructure that the commune offers.

However, Delmas has the highest unemployment rate. Nearly 27 percent of its residents have reported to be unemployed, compared to 14 percent in Port-au-Prince and 15.8 percent in Carrefour. It seems that the commune may have a "high dependency ratio", meaning family members who are dependent on others, and therefore are not employed. These can include business owners, professionals, and people in the diaspora. 


\section{Carrefour}

Carrefour is located on the South Side of the capital. It has the highest number of uneducated people among the three cities. Nearly 40 percent of the population reported having no secondary education at all, compared to 29 percent in the commune of Port-auPrince and 21.4 percent in Delmas. About one third of the population has a primary education, nearly 46 percent have high school diplomas, and 12.5 percent have some kind of college education (Table 5.1).

Carrefour is the home of the largest lower-class population among the three cities. Nearly half of the population identifies as working-class, while a little more than half identifies as middle class. Carrefour has the lowest number of people that identify themselves as upper class, which represents only one percent of the city's population. About 70 percent of the carrefour population is earning their living from off informal jobs. Only 14.3 percent of the population is employed in the formal sector.

\section{The Damages and Life Perturbation}

This section analyzes both the damages and perturbations that the earthquake caused in the lives of the people of Port-au-Prince based on three communes surveyed. First, we proceed to provide a general assessment of the damages and suffering as a result of the earthquake. Second, we consider the perturbations caused by the earthquake as a result of loss of health, property, and income. 


\section{Table 5.2: General Damage Assessment}

Distribution of households by commune according to whether they declared having suffered losses resulting from the earthquake

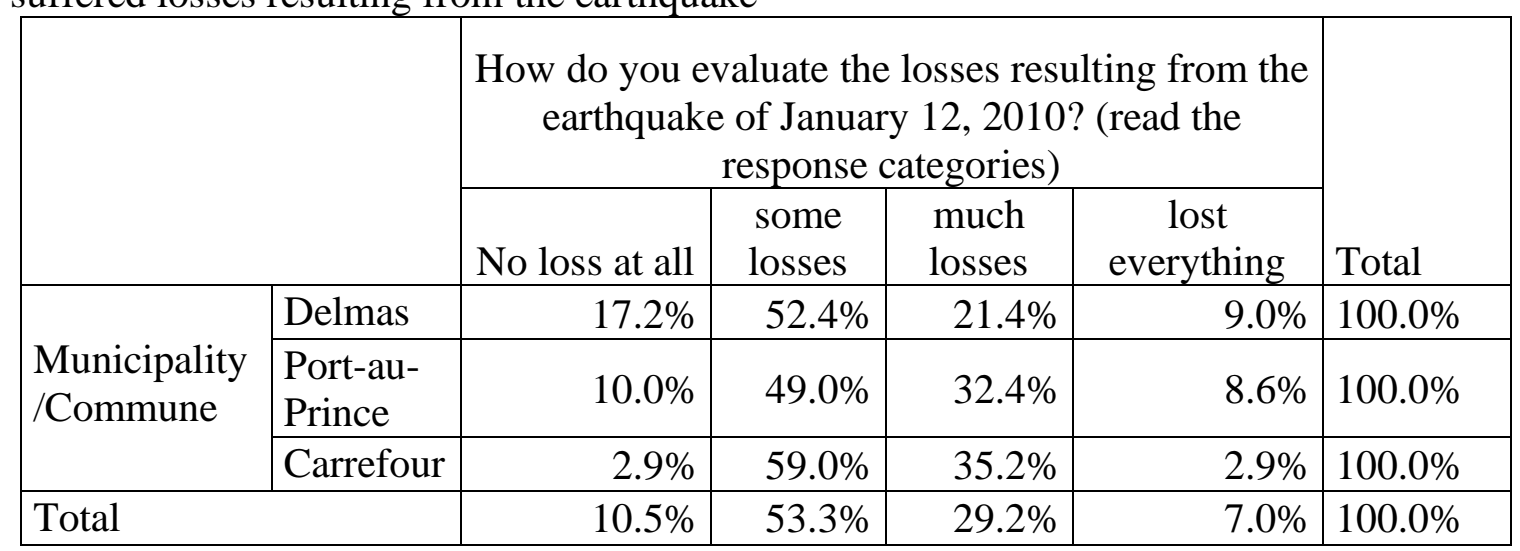

Source: Haiti Resilience Survey (Analytic N=889).

Table 5.2 presents the households assessment of damage as a result of the earthquake. We asked the question: How do you evaluate the losses resulting from the earthquake on January 12, 2010? The categories of response were: $0=$ no loss; $1=$ some loss; $2=$ much loss; $3=$ total loss.

The table demonstrates extensive damages across all the communities. About 83 percent of households in Delmas experienced some degree of losses, compared to 90 percent in Port-au-Prince and nearly every household in carrefour experienced some degree of loss and damages.

While the commune of Delmas had the largest number of households that experienced no loss at all, it also had the highest number of households that lost everything: 9 percent in Delmas compared to nearly 3 percent in Carrefour. However, Carrefour has the highest number of respondents reporting that they had many losses with a percentage of 35.2. The difference between Delmas and the commune of Port-au-Prince regarding the number of households declared to have lost everything remains very small. 8.6 percent of 
residents in the commune of Port-au-Prince reported that they lost everything, compared to the 9 percent in Delmas. The conclusion is that all the communes had suffered significantly from the earthquake.

\section{Table 5.3: Long-term Health Perturbances}

Distribution of households by municipality according to whether they declare having chronic health problems resulting from the earthquake.

\begin{tabular}{|c|c|c|c|c|}
\hline & & \multicolumn{2}{|c|}{$\begin{array}{l}\text { Is there anyone in your } \\
\text { household who has long-term } \\
\text { health problems as a result of } \\
\text { the } 2010 \text { earthquake? }\end{array}$} & \multirow[b]{2}{*}{ Total } \\
\hline & & No & Yes & \\
\hline \multirow{3}{*}{$\begin{array}{l}\text { Municipality } \\
\text { /Commune }\end{array}$} & Delmas & $84.6 \%$ & $15.4 \%$ & $100.0 \%$ \\
\hline & Port-au-Prince & $77.2 \%$ & $22.8 \%$ & $100.0 \%$ \\
\hline & Carrefour & $72.9 \%$ & $27.1 \%$ & $100.0 \%$ \\
\hline \multicolumn{2}{|l|}{ Total } & $78.7 \%$ & $21.3 \%$ & $100.0 \%$ \\
\hline
\end{tabular}

Source: Haiti Resilience Survey (Analytic N=889)

Table 5.3 assesses the long-term health consequences across the communes as a result of the consequences of the earthquake. We asked the question: Is there anyone in your household who has long-term health problems as a result of the 2010 earthquake? The categories of response were: $1=$ yes; $0=$ no.

The figures demonstrate that the residents in Delmas expressed slightly less longterm health concerns compared to the residents in Port-au-Prince and Carrefour. Although, the difference between the residents in Carrefour and those in Port-au-Prince are almost insignificant, the data shows Carrefour suffered slightly more from long-term health issues than the residents of Port-au-Prince. We can conclude that the commune of carrefour 
suffered more from long-term health problems compared to the other communes' residents. However, the differences among the three communes were minimal.

\section{Table 5.4: Loss of Property}

Distribution of households by municipality declaring having lost their homes

\begin{tabular}{|c|c|c|c|c|}
\hline & & \multicolumn{2}{|c|}{$\begin{array}{l}\text { Did you lose your home during } \\
\text { the } 2010 \text { earthquake? }\end{array}$} & \multirow[b]{2}{*}{ Total } \\
\hline & & No & Yes & \\
\hline \multirow{3}{*}{$\begin{array}{l}\text { Municipality } \\
\text { /Commune }\end{array}$} & Delmas & $63.3 \%$ & $36.7 \%$ & $100.0 \%$ \\
\hline & Port-au-Prince & $73.4 \%$ & $26.6 \%$ & $100.0 \%$ \\
\hline & Carrefour & $84.2 \%$ & $15.8 \%$ & $100.0 \%$ \\
\hline \multicolumn{2}{|l|}{ Total } & $73.0 \%$ & $27.0 \%$ & $100.0 \%$ \\
\hline
\end{tabular}

Source: Haiti Resilience Survey (Analytic N=889)

Table 5.4 presents the household's assessment of damages resulted from the earthquake across the three communes as it relates to residents indicating having lost their homes. We asked the question: Did you lose your home during the earthquake? The data shows that Delmas was the hardest struck by the earthquake with highest assessed losses of homes. Nearly 37 percent of households in Delmas declared having lost their homes, compared to 26.7 percent in Port-au-Prince, and 15.8 percent in Carrefour. The data indicates also that the household assessment of damage was less in Carrefour compared to the two other communes. This can be explained by the fact that the homes in Carrefour were more resilient because of their simplicity. 


\section{Table 5.5: Financial Loss}

Distribution of households having suffered a loss of income due to the earthquake

\begin{tabular}{|l|l|r|r|r|}
\hline \multicolumn{2}{|c|}{} & \multicolumn{2}{|c|}{$\begin{array}{c}\text { Did you lose your job after the } \\
\text { January 12, 2010 earthquake? }\end{array}$} & \multirow{2}{*}{ Total } \\
\cline { 3 - 5 } \multicolumn{2}{|c|}{} & No & \multicolumn{1}{|c}{ Yes } & \multicolumn{1}{c|}{$100.0 \%$} \\
\hline \multirow{3}{*}{$\begin{array}{l}\text { Municipality/ } \\
\text { Commune }\end{array}$} & Delmas & $79.2 \%$ & $20.8 \%$ & $100.0 \%$ \\
\cline { 2 - 5 } & Port-au-Prince & $77.2 \%$ & $22.8 \%$ & $100.0 \%$ \\
\cline { 2 - 5 } & Carrefour & $72.5 \%$ & $27.5 \%$ & $100.0 \%$ \\
\hline
\end{tabular}

Source: Haiti Resilience Survey (Analytic N=889).

Table 5.5 indicates the household assessment of their financial loss resulting from the earthquake. We asked the question: Did you (or any member of the household) lose your job after the January 12, 2010 earthquake? The categories of response were: $1=$ yes; $0=$ no. Based on the respondent's assessment, the data indicates slightly less number of individuals lost their income in Delmas compared to Port-au-Prince. The individual assessments of income lost was higher in Carrefour. Compared to Delmas, about 7 percent more respondents in the Commune declared having lost their income as a result of the earthquake. This difference between the two communes may be explained. By the fact that Delmas has a higher dependency ratio than Carrefour. As a result, fewer people lost their incomes as a result of the earthquake.

\section{Recuperation and Recovery}

This section analyzes the perceived household recovery from the earthquake. It intends to make examine to the respondents' assessment as to the extent to which their households have been able to regain the same level of social and economic capacity as before the 
earthquake. We asked the question: how far have you recovered from the 2010 earthquake? The categories of answer were: $1=$ no recuperation at all; $2=$ somewhat recuperated; $3=$ largely recuperated; 4 = completely recuperated.

\section{Table 5.6: Perceived Recovery}

Distribution of households affected by the earthquake by commune and according to their level of recovery.

\begin{tabular}{|c|c|c|c|c|c|c|}
\hline & \multicolumn{4}{|c|}{$\begin{array}{l}\text { How far have you recovered from the } 2010 \\
\text { earthquake? (read the response modalities) }\end{array}$} & \\
\hline & & \begin{tabular}{|c|} 
No \\
recuperation \\
at all \\
\end{tabular} & $\begin{array}{l}\text { somehow } \\
\text { recuperated }\end{array}$ & $\begin{array}{l}\text { Largely } \\
\text { recuperated }\end{array}$ & $\begin{array}{l}\text { Completely } \\
\text { recuperated }\end{array}$ & \\
\hline \multirow{3}{*}{$\begin{array}{l}\text { Municipality } \\
\text { City }\end{array}$} & Delmas & $17.2 \%$ & $63.3 \%$ & $9.3 \%$ & $10.2 \%$ & $100.0 \%$ \\
\hline & \begin{tabular}{|l|}
$\begin{array}{l}\text { Port-au- } \\
\text { Prince }\end{array}$ \\
\end{tabular} & $19.3 \%$ & $63.4 \%$ & $9.7 \%$ & $7.6 \%$ & $100.0 \%$ \\
\hline & Carrefour & $21.6 \%$ & $56.0 \%$ & $14.3 \%$ & $8.1 \%$ & $100.0 \%$ \\
\hline \multicolumn{2}{|l|}{ Total } & $19.2 \%$ & $61.1 \%$ & $10.9 \%$ & $8.7 \%$ & $100.0 \%$ \\
\hline
\end{tabular}

Source: Haiti Resilience Survey (Analytic N=889).

The data in Table 5.6 shows a consensus in assessments that there has been very little recovery among the households across the three communes. On average only a few families indicated that they were able to recover from the earthquake. More than 90 percent of households across all three communes self-reported as having not fully recovered from the consequences of the earthquake. 


\section{Discussion}

The purpose of the first set of figures was to demonstrate differences in vulnerabilities across the three communes based on the effects of the earthquake. The data shows all the communes were severely damaged by the earthquake. The data also indicates very little differences in the assessed damages among the communities except for income losses that can be explained by differences in dependency ratios.

The second set of figures demonstrate that, despite these differences, none of the communities has recovered. More than 90 percent of respondents declared themselves to have not recovered. As a result, the data indicates that resilience has not occurred in all three of the communes indicating a failure of recovery efforts. This indicates a failure of efforts to build capacity for resilience into the relief efforts.

\section{Summary}

This chapter demonstrated both the degree of concern as well as the extent of the international community's commitments to help Haiti in the wake of the devastating earthquake. This concern led to the International Donors Conference, Toward a New Future for Haiti, in which the international community committed to fund a massive relief effort to help the country. The commitments came with the prospect of rebuilding the country through sustainable development projects and goals, reinforcing government effectiveness, and promoting disaster resilience. I demonstrated in this chapter that the commitments expressed at the conference were not realized based on the assessments of respondents. People are claiming that they are still suffering from the effects of the 
earthquake on their health and economic conditions. Therefore, it indicates the failure of resilience, which I will discuss more in the next chapter. 


\section{Chapter Six: NGOs and Disaster Aid: Towards a New Approach}

In Chapter Five, I discussed the failure of the post-disaster intervention. I attributed the failure mainly to the inadequacy of the efforts to increase people's capacities and reduce

their vulnerability, and to state incapacity, which prevented both a successful oversight of the intervention and a dynamic collaboration between the NGOs and the government. At this juncture, the question to be answered pertains to the way disaster aid can be delivered to produce positive outcomes. This chapter argues for a need to shift funding for disaster aid. Funds should be distributed to local NGOs and development agencies and coordinated with effective local governments. The latter can work as collaborators, in the face of an ineffective national government.

Ideally, the national government should have the responsibility to create the conditions for development, develop policies and practices that can build resilience, and orient aid and assistance in the direction that can create long-term positive outcomes. NGOs are not able to replace the state at that level. Given the incapacities and incapabilities of the national government, the most effective option is for NGOs to implement development work with local governments and local organizations.

\section{Functional Limit of NGO Intervention in Haiti}

Regardless of whether the NGOs' intentions are good, dependence on NGO has its severe limitations. If sustainable interventions are to be enacted, ideally there is a need for an effective state. These limits are echoed in the statements of the university professors that I 
interviewed. Professor Pierre Buteau argued that Haiti's development cannot be entrusted to NGOs:

We saw the intervention of NGOs after the earthquake. These NGOs, in many respects, are solid, honest, and serious. They have brought short-term relief, which has improved the situation of people. They have enabled a good number of families to get by. NGOs are very helpful. But we cannot entrust the destiny of a country like Haiti to NGOs with regard to major infrastructure projects, major infrastructure works, also with regard to serious development projects. 15

Development is not the responsibility of NGOs, and NGOs understand that, said Professor Abnel Desamours:

The responsibility [of development] is not NGOs'. In general, NGO leaders tell you that this is not their mission. They tell you that this is the mission of the state. They tell you that an NGO is not the one to fund long-term activities. First, the very structure of NGOs does not allow them to fund such activities. Sometimes an NGO exists to solve a problem. The NGO disappears with the resolution of the problem. You can channel the funds through NGOs. But there are things that you cannot ask NGOs to do.

Professor Dorvilier posed the problem of the weakness of national institutions and the way aid has been operationalized on the ground:

Internally, there is the problem of de-structuration of internal institutions which has a direct impact on aid effectiveness. If the institutions do not work, if there is a lack 
of competence in the country, if there is a lack of human resources in the country, if the governance is weak, if the population is at such a low level, aid cannot really work miracles in any way. There is not only the very, very, very high level of poverty, there is also the failure of basic institutions. Internal actors cannot think of aid and operationalize aid on the ground because the needs are so immense, aid is like a drop in the ocean. It is not aid per se, aid is sometimes the channeling in areas that it should not be used, but I believe that aid is important. NGOs are important. God only knows! if there were no NGOs in the country, there would be famine, riots, uprisings etc.

Therefore, there is a need for a new approach.

\section{Reinforcing Local NGOs and the Collaboration with Local Governments}

In the face of an ineffective and corrupt state, I argue for a locally-based strategy where donors can work with local NGOs, local organizations and agencies with proven track record, and effective local government in order for the interventions to be successful.

Working with local NGOs offers many advantages. First, it reduces the need for expatriates and places the money directly in the hands of those who can implement projects on the ground. We know that NGOs attract their personnel by offering the opportunity to function in relatively acceptable conditions. Otherwise, expatriates would not work for NGOs, if they were required to give up their lifestyle and forced to live under the same conditions as locals. However, there is considerable resentment expressed by some Haitians over NGOs use of expatriates and dependence on foreign resources. The 
administrator of a small local charity who works in health care education, voiced those resentments in this way:

The money, most of it was spent on getting all kinds of stuff to put over here. They come and stay in expensive hotels, rent expensive cars, and go to expensive beaches and stuff like that, you can see that. It is not in their interest to help Haiti develop. 16 A second advantage that working with local NGOs and agencies provides is that local organizations are more suited to identify the needs of the population. Such an argument was underscored during the focus group that I conducted with local organizations working in Port-au-Prince.

\section{Focus Group: Methodology}

I employed the focus group to complement the data that I got from the institutional ethnography and in-depth interviews. It is necessary to mention that a focus group, as a qualitative method, whether used alone or in triangulation with other methods of data collection, is relevant for evaluative research, analysis of motivational factors, action research or research and development, and to facilitate needs analysis (Van Der Maren, 1995: 67). I conducted the group discussions with three community org anizations that work in Port-au-Prince. I chose one organization per commune. Two of them were women's organizations.

I selected the organizations with the help of the Cadre de Liaison Inter-Organisation (CLIO), (Inter-Organizations Framework), an association of organizations that put together 
more than sixty-six Haitian and foreign NGOs. With CLIO's assistance I contacted an organization that works closely with NGOs. They agreed to participate in the research and shared contacts of other organizations that work in different communes. I then contacted about six of these organizations. Only two of them agreed to participate in the research. So, I completed the group discussion with a total of three organizations.

I, myself, conducted the group discussion with each organization separately. Each group discussion was composed of five to eight individuals. Most of them were board members. A few of them were regular members. The leader of each organization signed the consent form prior to discussion. The groups gave me authorization to record the interviews and to use the official name of their organization. As such, the organization names that I mentioned above are not pseudonyms, but rather their real and official names.

\section{Focus Group Discussion}

During a focus group with the Organization pour le Développement Social et de l'Encadrement Technique des Artisans d'Haiti (ODSETAD) (Organization for the Social Development and Technical Support of Haiti's Artisans) and Sauve Fanm (Save the Women) the issue of NGO projects as they relate to the real needs of the population surfaced as well. The members of the group suggested that NGOs work with community organizations to design and implement their projects. As community organizations, they believe that they are closer to the population, and they know precisely the kind of projects that will make a difference in people's lives. This was particularly the position of group members from the women's organizations, who pointed out the pervasive neglect by NGOs 
of women's issues and their financial, economic and social needs. This forced them to organize and advocate for themselves.

Local governments are more aware of the problems that their communities are facing. It is important that local governments are reinforced, and their capacities are increased. Effective collaboration between local governments, local agencies and NGOs can bring successful results, as they identify the real needs of the population and provide assistance accordingly. For example, participants in a focus group for one of the organizations voiced the fact that community organizations know the issues that people in the lower strata of the society are experiencing. The participants advocated for better coordination between NGOs and community organizations:

When it is an NGO that has the power of money in its hands, if there is no framework between the state and NGOs, between community leaders and NGOs, to sit together, identify the needs of the community, we will not find a solution. As long as we don't do this, problems will continue to be repeated every day. Because what is important? When a donor gives money to an NGO for a specific project, for example, he gives money for agriculture. The NGO must act upon specific areas in agriculture if he really wants to support agriculture. Otherwise, you may see the destruction of agriculture instead of supporting and developing national products. That is what we are facing here.17

The participants in the focus groups also advocated for what they saw as the most important needs of the population: social security, job creation, reforestation programs, and loan

17 Focus group with OSETAD and Save the Women. 
programs for the informal sector. They argued that while the NGOs may not be able to implement these programs, as community organizations, they can, and they know how to make them work.

Those arguments helped me to understand the importance of a locally centered intervention as the best way to produce positive outcomes -- by directly attacking the roots of people's vulnerabilities and increasing their capacities. It requires local authority guidance and collaboration. More specifically, local NGOs and agencies are more suited for this work. Development NGOs that have the money to intervene can do so as well, but under the guidance of the local community and a framework that is designed by the local governments. One example of such an arrangement is the Morakot post-disaster intervention, which I will discuss more in the next chapter.

\section{Unrealized Goals}

In prelude to the International Donors Conference, The UN Secretary-General stated that "our goal is not to rebuild. It is to build back better". He also added "as we move from emergency aid to longer-term reconstruction, let us recognize that we cannot accept business as usual. What we envision, today, is wholesale national renewal, root to branch -- a sweeping and ambitious exercise in nation-building." (UN, 2010). At the conference, promises were made to build a new and sustainable Haiti.

However, ten years later, the goals have not been materialized. As an example, major government buildings are still not rebuilt. Indeed, most of the buildings that house the government's officials and the ministries have not been rebuilt, nor repaired. The Haitian government is still functioning in broken and damaged buildings. Indeed, nothing 
symbolizes the failed reconstruction more than The Palais National (National Palace). The Palace was severely damaged during the earthquake. It was demolished in 2012. Although in 2017, Haiti's President, Jovenel Moise announced a plan to rebuild the Palace (McFadden, 2017), the construction has still not yet begun. The office of the presidency since the earthquake has been housed in a building in the backyard of the Palace.

Similarly, serving as a reminder of unrealized goals is the Palais de Justice (Justice Palace) building, which used to house the Cour de Cassation, (the equivalent of the Supreme Court in the U.S.), the Appeal Courts, and some other special courts or Jurisdictions. Figure 6.1 shows the Justice Palace before the earthquake, a very prestigious building. The building sustained heavy damage resulting in a partial collapse on January 10 as a result of the earthquake (see Figure 6.2). The structure was still not rebuilt in 2019.

The courts are now located in different offices of the capital.

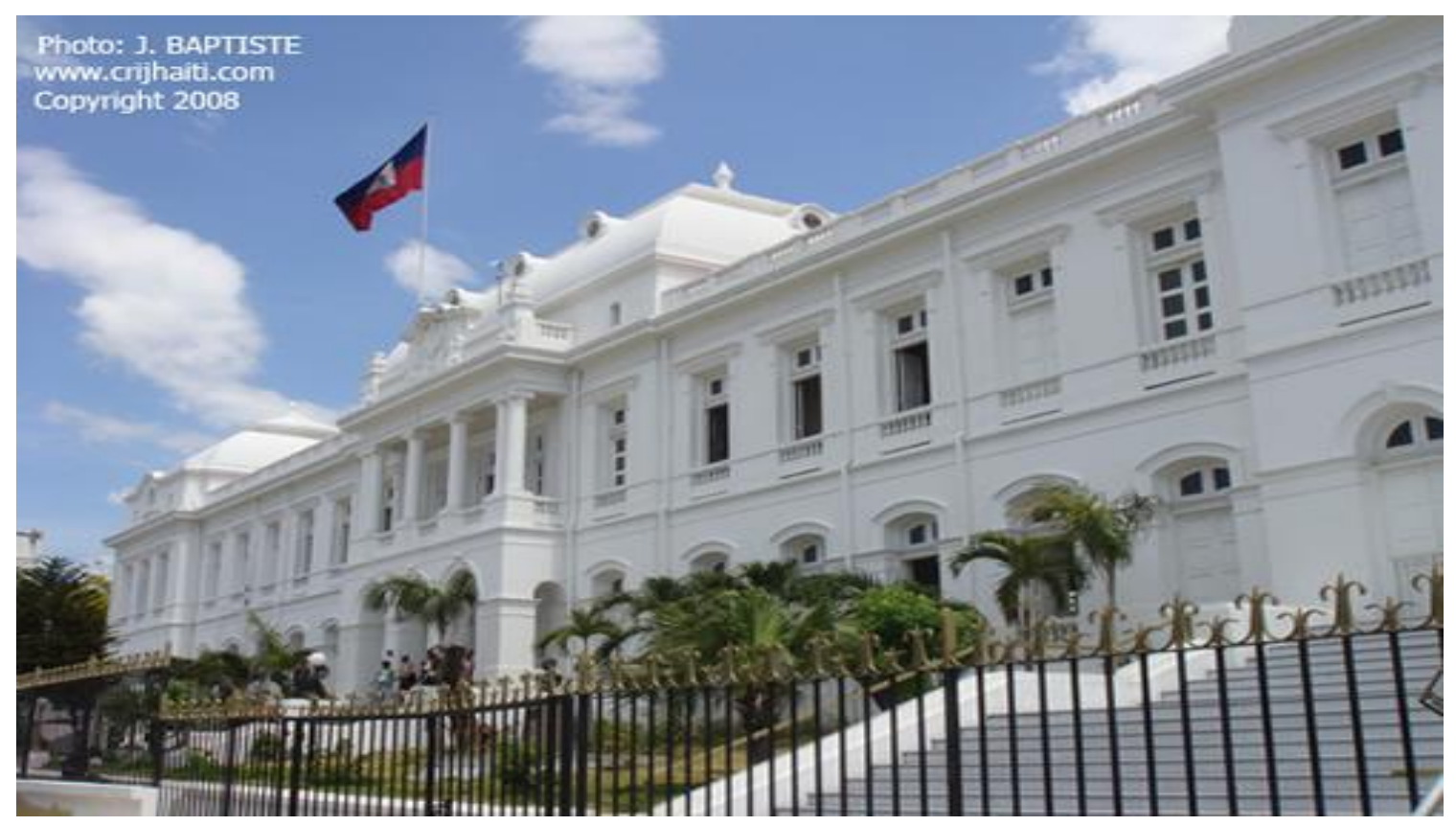

Figure 6.1: Palais de Justice (Justice Palace) before the earthquake 


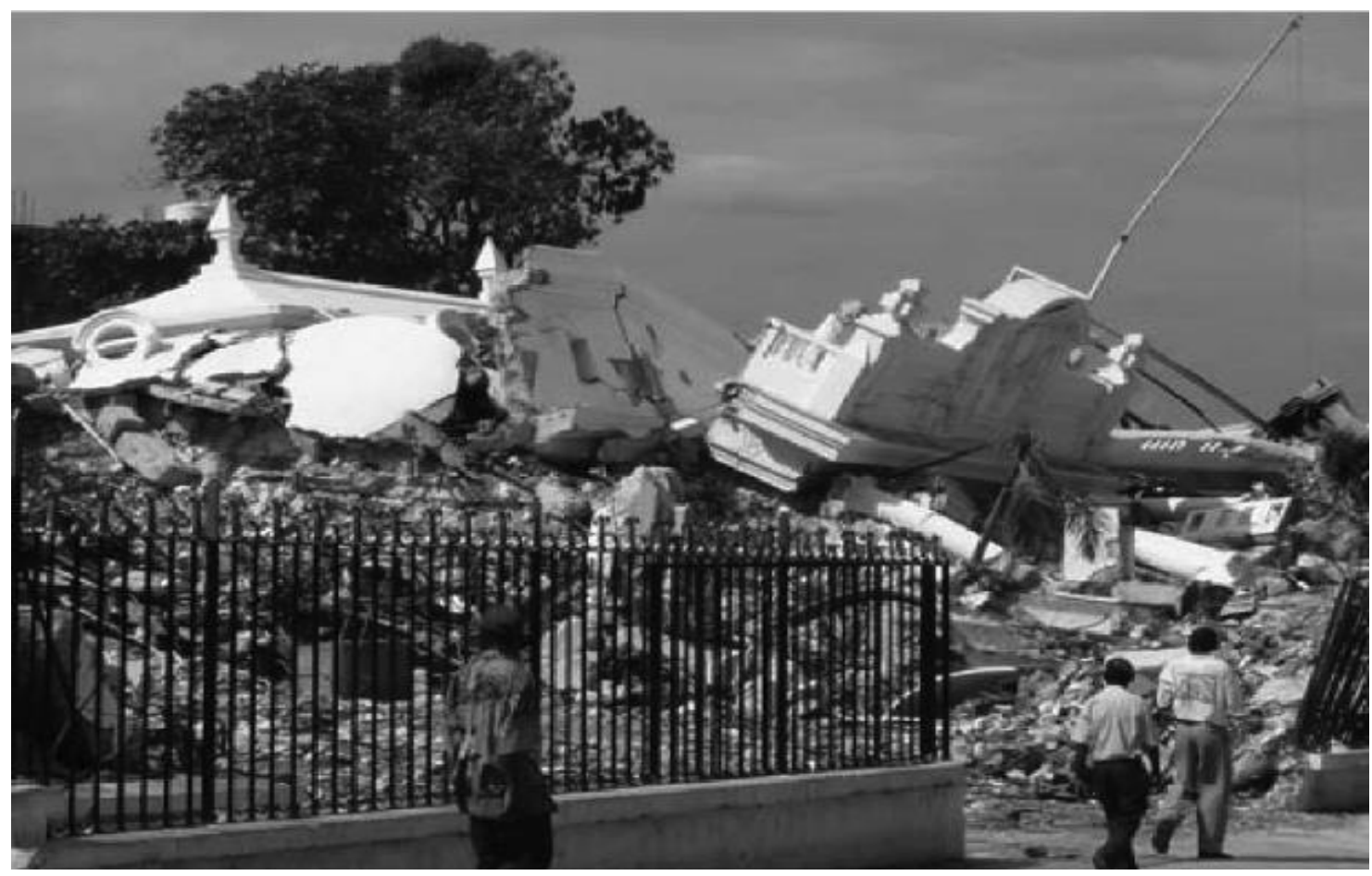

Figure 6.2: Palais de Justice (Justice Palace) in Haiti after the earthquake

Other important buildings that were destroyed have still not been rebuilt, including the Haitian Parliament that was also destroyed by the earthquake (see Figure 6.3). It has not been restored or replaced. According to Haiti Libre (2018), the construction of the new National Parliament was stopped. A new structure with four buildings will be built on the same site as the old parliament. However, I visited the construction site, and there was no indication that the work is ongoing. In Figure 6.4, I present a model of the new building. 


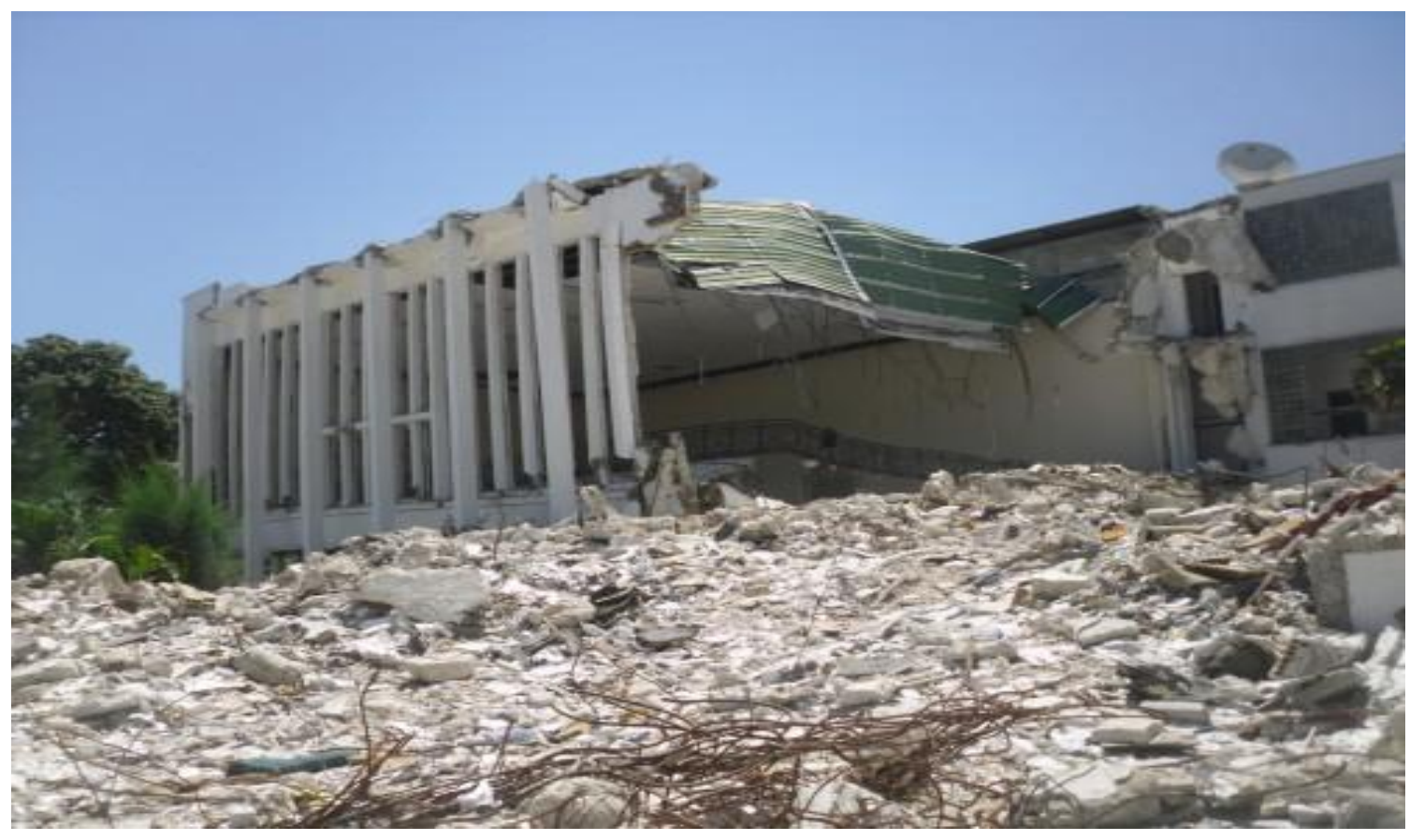

Figure 6.3: Palais Legislative (Legislative Palace) damaged by the earthquake.

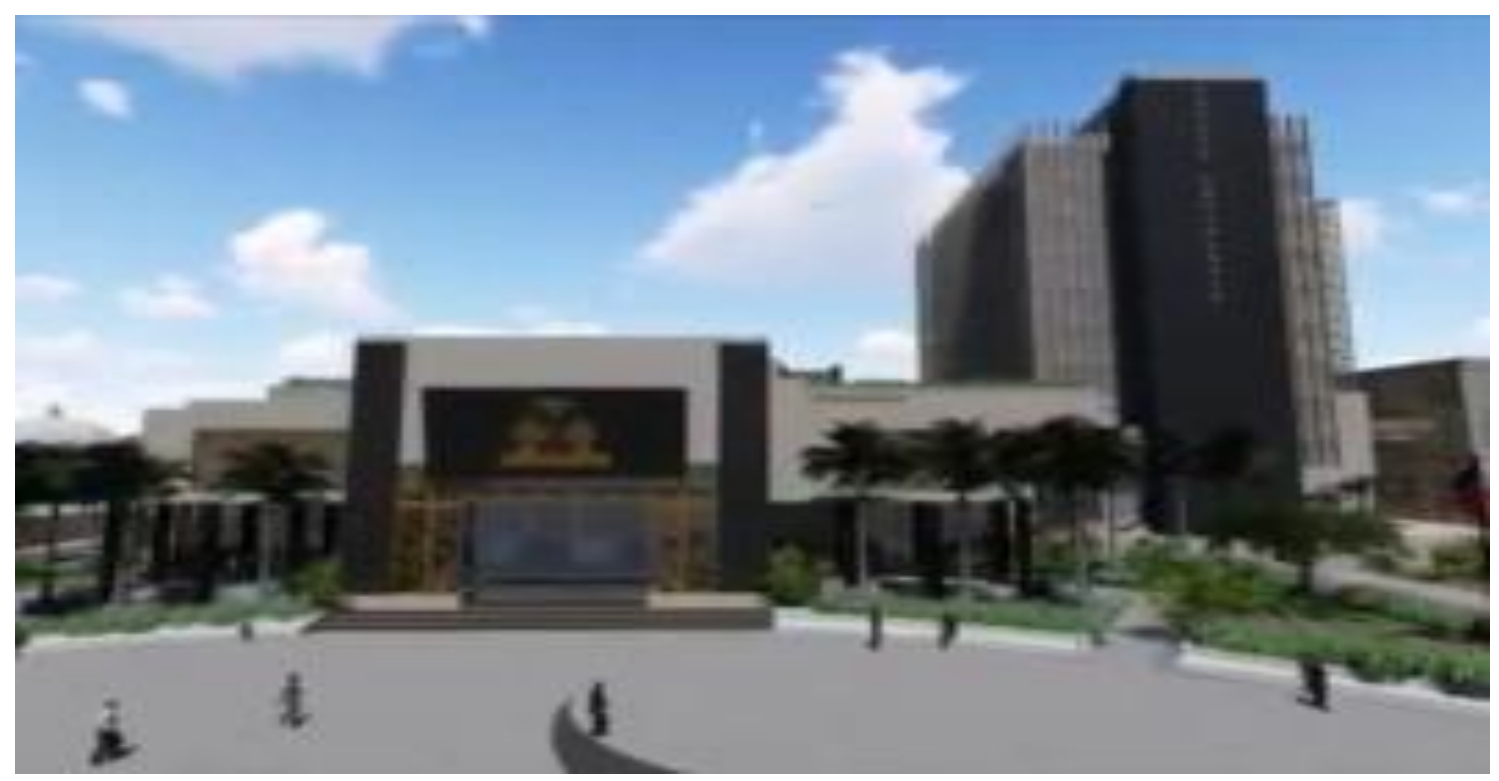

Figure 6.4: The model of the New Parliament building18.

18 The construction work of the new Haitian Parliament started by the Dominican firm Hadom and then suspended by the Government of Haiti. It is planned to continue with the Chinese firm Hongyan Construction Company Limited (Haiti Libre, 2019). 
The same is true of the cathedral of Port-au-Prince, a symbol of pride for the Haitians. Figure 6.5 shows the cathedral before the earthquake. The building was severely damaged as the result of the earthquake (see Figure 6.6). The cathedral archbishop at the time of the earthquake predicted that it might take more than twenty years before the country could come up with 30 to 40 million USD to rebuild the cathedral, and called for parishioners to contribute (The Atlantic, 2019). Of course, this example has also a lot to do with the complexity of the rebuilding effort and the need for funding. Not all the blames can be laid upon the inefficiency of the national government.

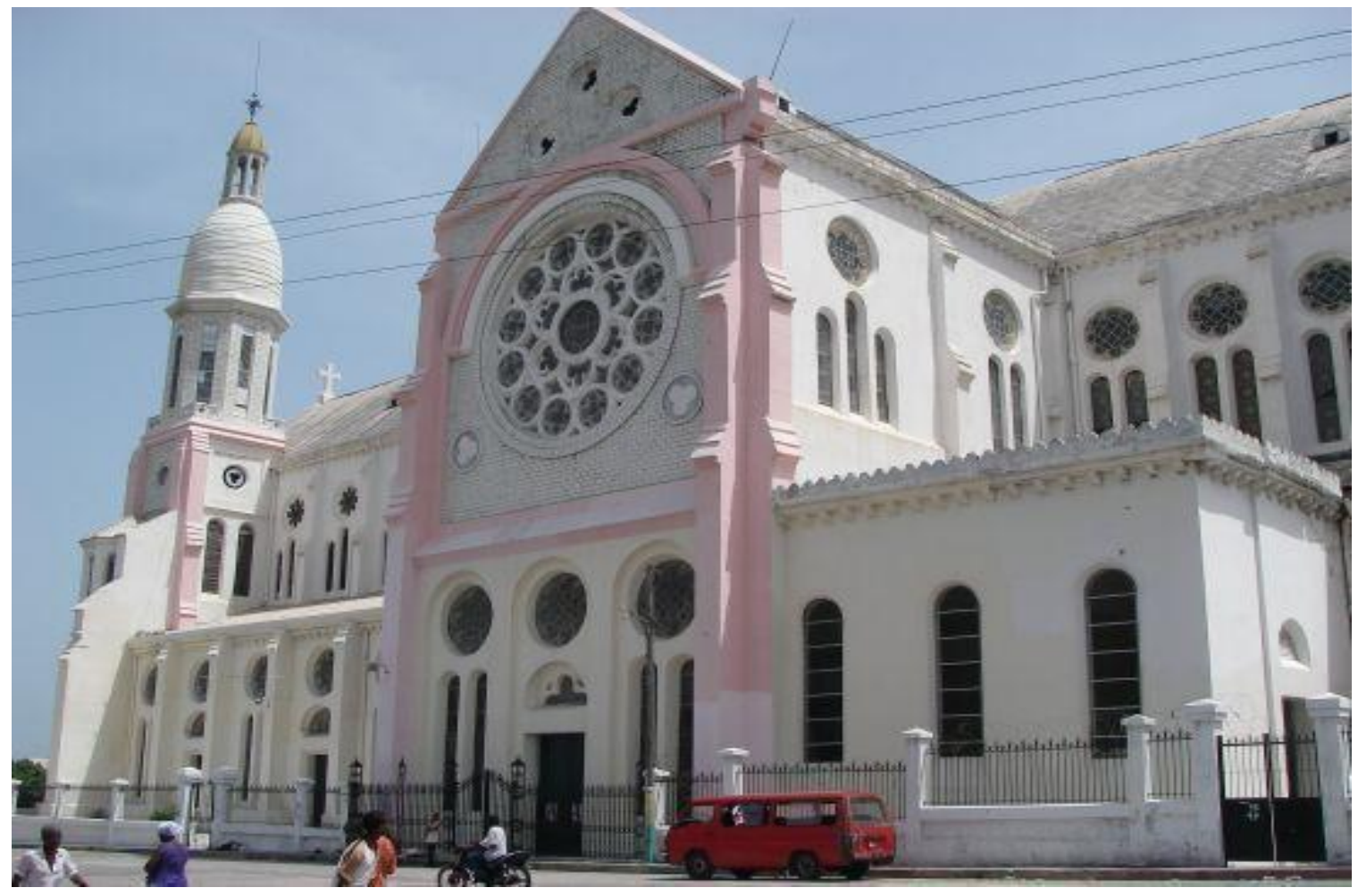

Figure 6.5: Cathedral of Port-au-Prince before the earthquake. 


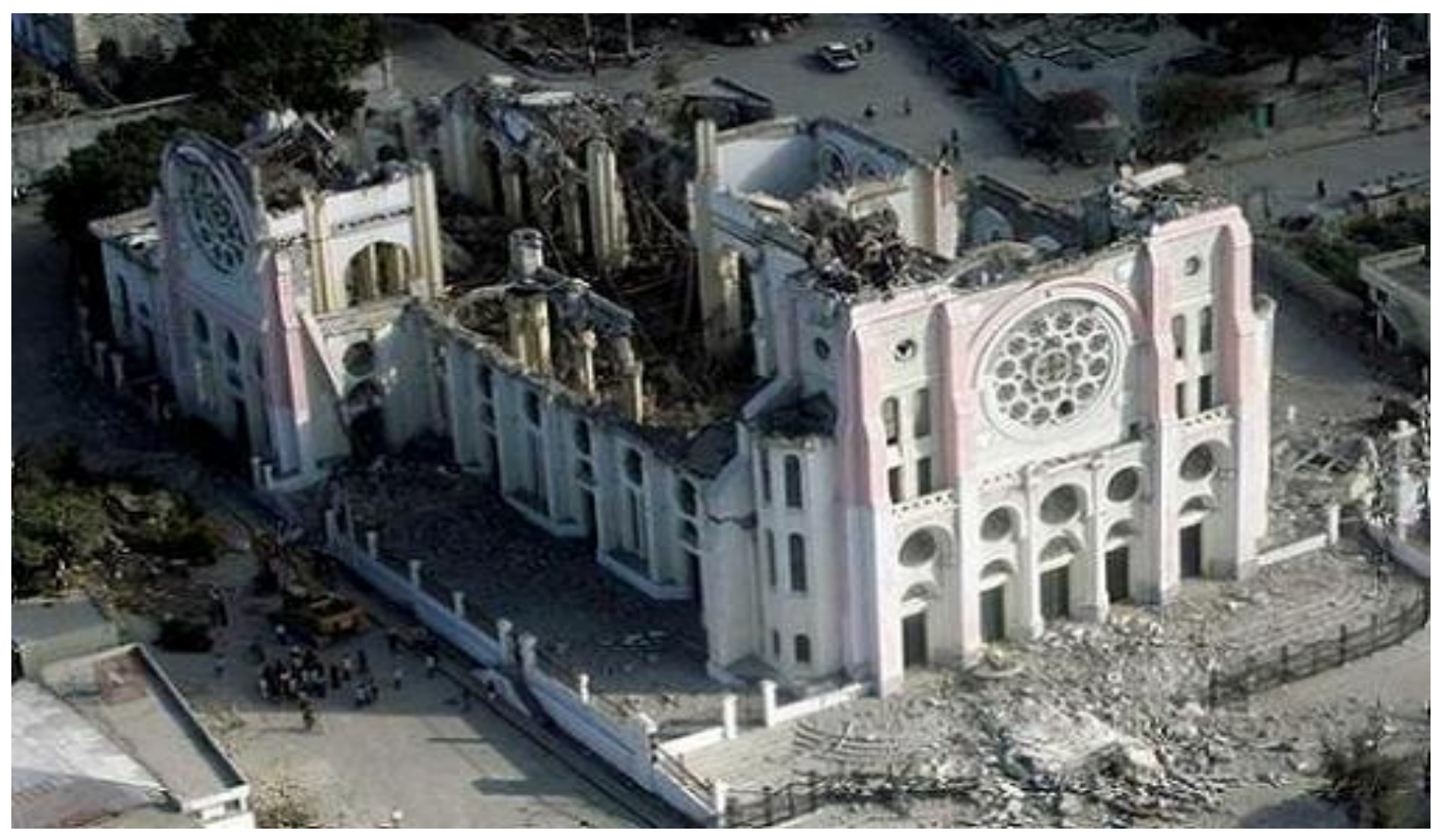

Figure 6.6: Cathedral of Port-au-Prince, Haiti, damaged by the earthquake.

\section{New Vulnerabilities}

The Haitian population has not yet recovered from the damages and consequences of the earthquake, as evidenced by the household survey conducted for this dissertation. Besides the survey data, my encounters with the Haitian people during my fieldwork and the interviews that I conducted point to a generalized belief by the Haitian people that social and economic conditions have been worsening since the earthquake. This comes with severe macroeconomic consequences. Recent World Bank (2019) figures indicate that during last few years, the country has experienced a rapid currency depreciation of almost $30 \%$, high levels of inflation of nearly $20 \%$, and a decline in GDP growth of $-0.9 \%$ during fiscal year 2019 . 
As a result, Haiti is now even more vulnerable to disasters since no real long-term rehabilitation work was undertaken during the period following the 2010 earthquake, despite foreign interventions and job creation projects. In addressing the question of whether Haiti is now more vulnerable to disasters, Frantz Dorvilier, Professor of Sociology of Development at Haiti State University stressed:

From an environmental point of view, there are things that have been done, other ways of building, training that have been done. I do not know if we are more vulnerable, but I know that we are still very vulnerable. Vulnerable from the environmental point of view, from floods, erosion, vulnerable to the diseases. We don't have more health centers than before the earthquake, not more sanitation projects in cities where implemented, nor more projects of decongesting urban centers. I think we are as vulnerable, but maybe we made some efforts in terms of awareness of climate hazards, and earthquake hazards.19

In other words, even though some things have been done, they have not reduced the vulnerabilities that existed before. This provides the rationale for my thesis -- that sustainable development and resilience need to be built into rehabilitation and reconstruction efforts. Otherwise, there will be a continuing and perpetual need for disaster relief.

The Project Director at Compassion International, argued with no equivocation that in the case of another earthquake hitting Haiti, there will be considerably more damage. He points out that the same building practices are being used as before the earthquake. He

19 Interview with Professor Fritz Dorvilier 
attributes this to failure of the Haitian government. One example of this failure is the failure to enforce building codes by the state. As a result, the preexisting vulnerabilities remain and even have increased.

As I have argued in Chapter two, even well-intentioned relief efforts may produce new and unforeseen vulnerabilities. This argument has been well developed by numerous scholars (Delica-Willison \& Willison, 2008; Hilhorst, 2008; Oliver-Smith, 2008; Roger, 2007). In the case of Haiti, the influx of NGOs in Port-au-Prince became a pull factor for internal migration. In the wake of the earthquake, Port-au-Prince became the center of aid activities and humanitarian intervention. It was in Port-au-Prince where food distribution activities and the distribution of supplies were centered, where the doctors and nurses who came to provide medical assistance and deliver medications were located, and where the NGOs planned the construction of temporary houses for people who had been displaced. People left the rural area and migrated to Port-au-Prince in massive numbers, hoping to benefit from the humanitarian assistance located in the capital city, no matter how inadequate. At the time of the quake, the population of the larger Port-au-Prince area was estimated at 2.1 million inhabitants (ERHW, 2020). In 2012, the population increased to 2.4 million (World Population, 2020). Today, Port-au-Prince is home to more than 2.7 million Haitians (World Population, 2020). With this internal migration, Port-au-Prince -which was already overpopulated -- became saturated. Existing slums have grown, and new slums are being built. 


\section{New Slums: The Case of Canaan}

There are problems related to the state incapacities that have increased vulnerabilities in the post-earthquake period. NGOs may not be able to resolve those problems without the collaboration with local governments and organizations. An example that attracted my attention is the creation of Canaan, a new slum in Port-au-Prince. The example of Canaan demonstrates the increased vulnerabilities produced by migration and the failure of NGO intervention in the absence of local government and local organizations.

Canaan was created following the earthquake. I learned about the community for the first time during an interview with an NGO director. He pointed to the community as an example of new zones of vulnerability created in Port-au-Prince after the earthquake. So, I decided to visit Canaan. Immediately upon my arrival, while I was taking pictures, I was advised by a young man to be very careful. He pointed to the precarity and uncertainty in the lives of the community's residents and their fears, based on rumors that he repeated, that the state was planning to come in and destroy people's houses. This was producing a great degree of hostility directed against the central government. His concern was that people would mistake me for a state official and attack me.

Canaan is a vast community located on the Northern side of the capital. It is situated on a hill that was almost uninhabited before January 2012. Despite the enormous risks and vulnerabilities, people have made the choice to live there because they have no alternatives. The roads are not paved. There is no running water. Few people have access to electricity and those who do gain such access by illegally running a power line from the closest main street from Canaan. 
Canaan is considerably different from Cité Soleil, the largest slum in Port-auPrince, where people build makeshift houses. In the latter the houses are built to better withstand earthquakes and other catastrophic events because of their makeshift nature. In Canaan most of the houses are built with blocks and a few with concrete roofs which make them much more vulnerable to destruction and increase the possibilities of massive casualties during earthquakes. There is also the significant risk of a possible landslide (see Figure 6.8). The community exists outside the jurisdiction of the central government and is under no municipal authority to cater to the needs of its residents, enforce codes and regulations, or provide services, facilities, and infrastructure. It is totally unregulated. 


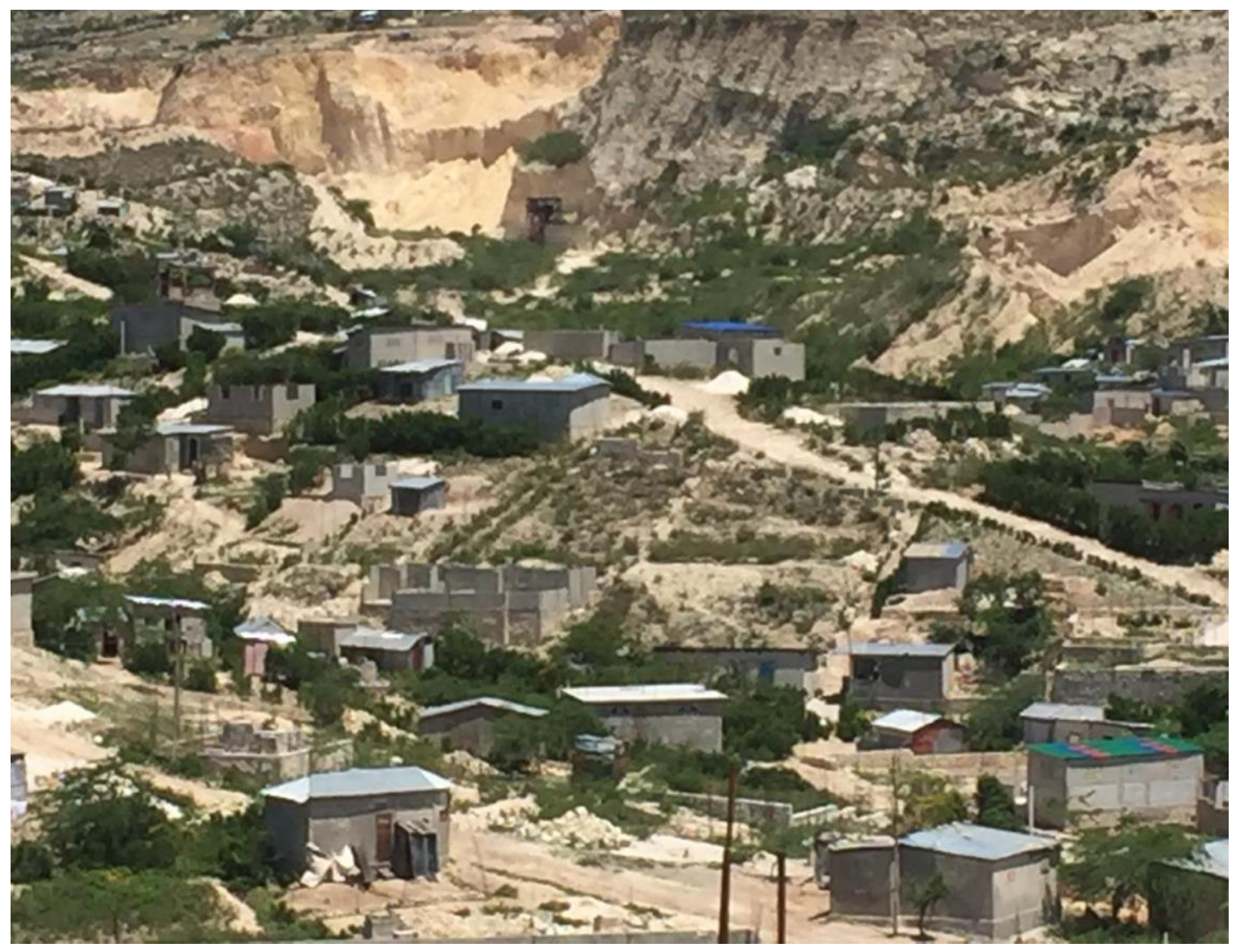

Figure 6.7: Photo exposing the risk of a landslide in Canaan20.

NGOs are certainly present in Canaan. They are involved in a project called "Action

Plan for Urban Re-structuration." The plan is being funded by Global Communities, an International NGO with its headquarters in Georgia, USA, and the American Red Cross (see Figure 6.8). The project was slated to last for five months. However, there was no evidence that the plan was being implemented. The example of Canaan indicates the failure

20 We can see how people built fragile structures downhill, exposing them to the risk of possible landslide. Photo taken in August 2019 during my fieldwork in Haiti. 
of the intervention to realize development transformation and how new vulnerabilities can be created despite the presence and the involvement of NGOs.

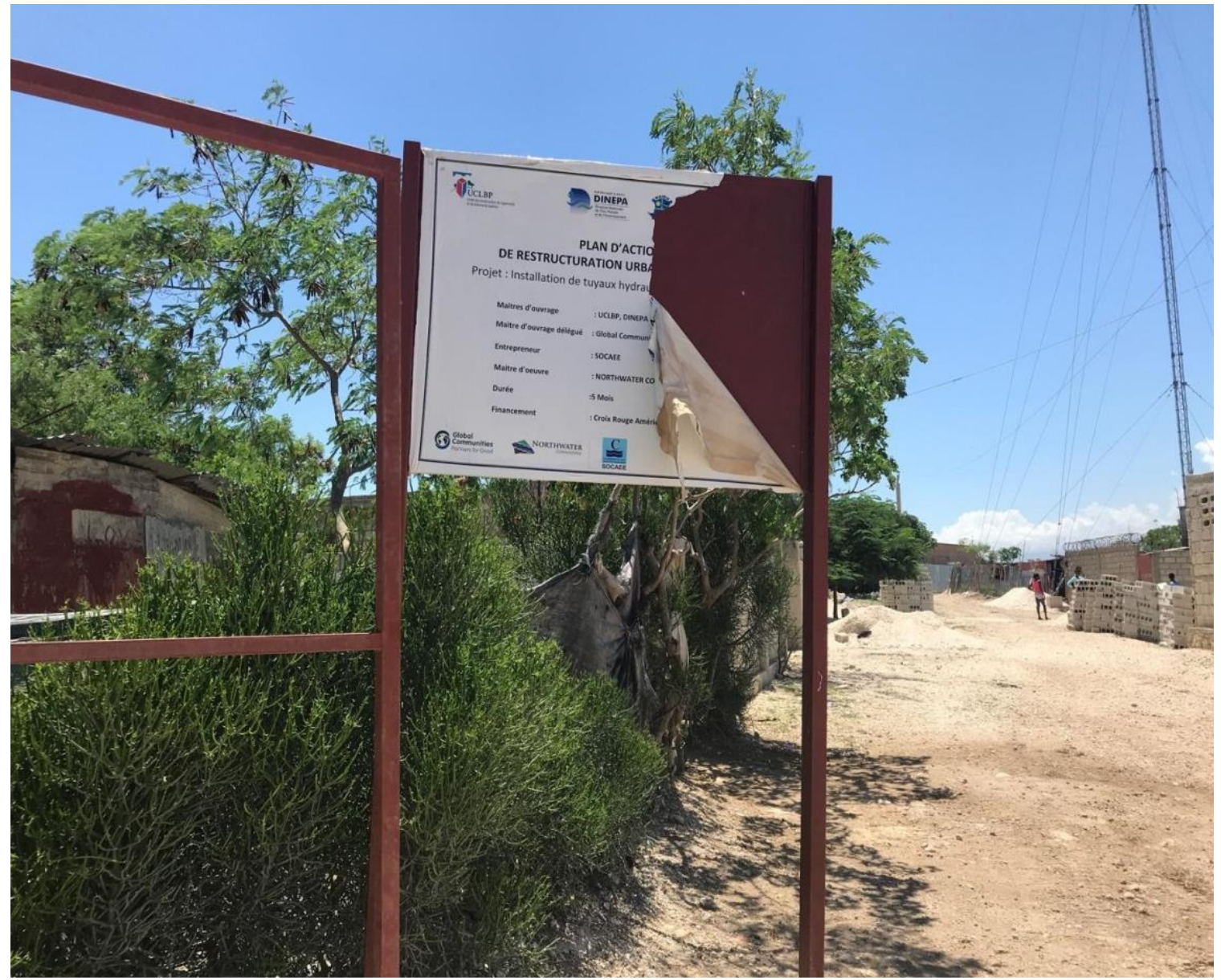

Figure 6.8: Action Plan for Urban Restructuration of Canaan.

\section{Ringing the Bell: Public Health and the Next Disaster in Haiti}

There are other problems related to the state incapacities that have increased vulnerabilities in the post-earthquake period. A case of concern relates to public healthcare. There have been significant concerns about Public Health and sanitation even before the earthquake, when more than $80 \%$ of healthcare delivery was provided by NGOs and private individual 
clinics (Schuller, 2012). The earthquake destroyed more of the already-limited capacities of the state public health care system, leaving health care delivery almost entirely in the hands of NGOs, whose primary focus is on basic healing, while neglecting prevention, hygiene, personal health practices, and other elements that constitute and promote robust public healthcare delivery. Health delivery worsened after a massive influx of rural migrants, and this caused the population to further depend on medications that were sold on the streets. This was typical even before the earthquake. People who could not afford to see a doctor or go to a pharmacy typically purchased medication based on self-diagnosis, or diagnosis from unlicensed vendors on the streets (see Figure 6.9). Street medications are less expensive than those sold in pharmacies. Vendors usually get their supplies from black market purchases in the Dominican Republic (Loop, 2019). It provides them with a source of income to support their families. With the massive inward migration to Port-au-Prince, the street-medication sales escalated dramatically. These sales exist outside the control of any government authority, are unlicensed, and are not reviewed for safety or authenticity.

People also rely on the vendors to diagnose their symptoms and prescribe the medications. The earthquake contributed significantly to the pre-existing vulnerabilities associated with these practices. They relate to a severe lack of pharmacists in Haiti. According to a study conducted by the Pharmacist Association of Haiti and the Ministry of Public Health and Population (MSPP) in 2013, only 676 people work in Pharmaceuticals in the country. Of these, only 196, which represent 29 percent, have a degree in Pharmacy. 


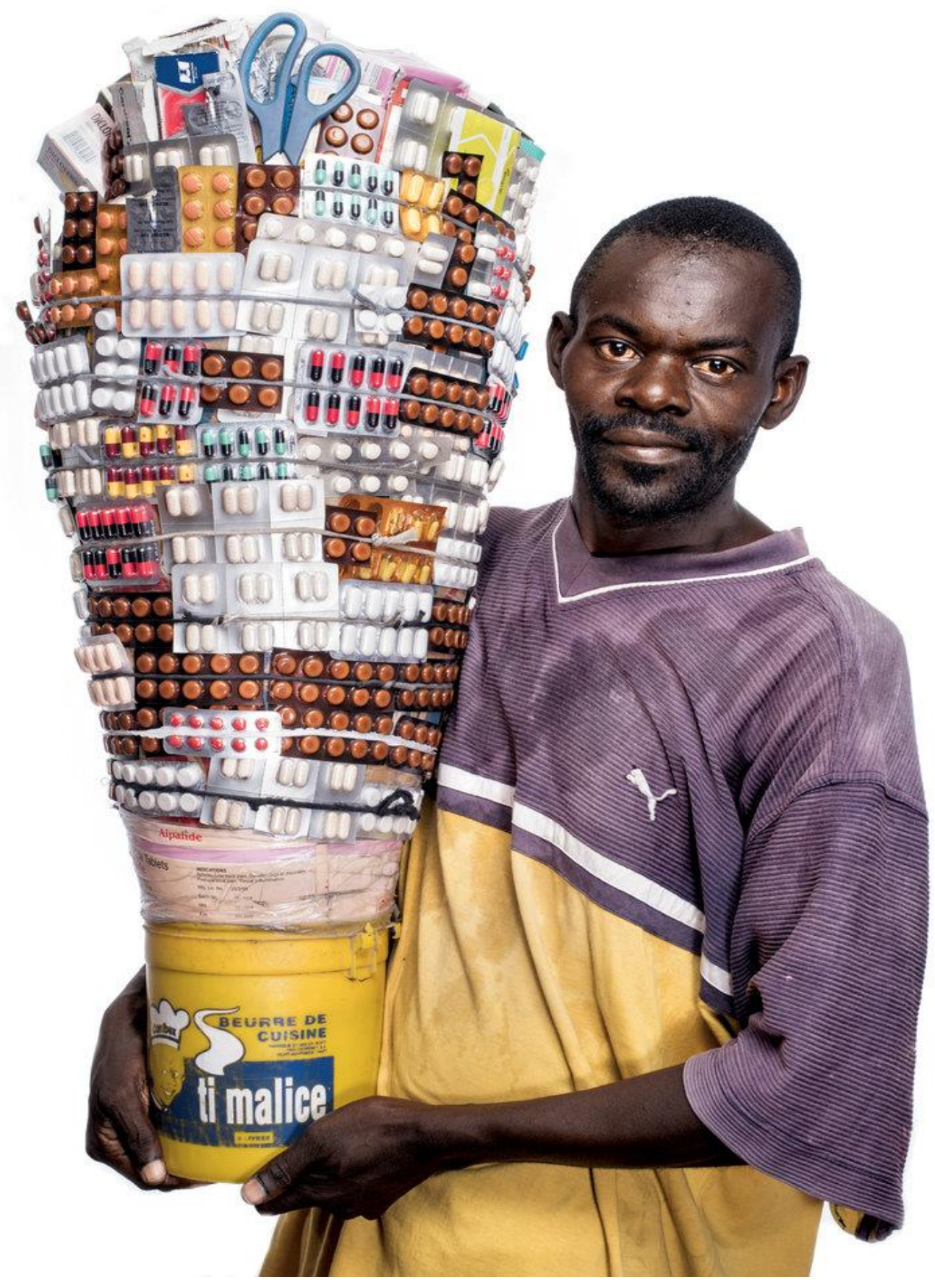

Figure 6.9: Ady Dumé, 38, street medications vendor21.

21 Picture taken by National Geographic. 
This is well below the requirement of 25 pharmacists for every 10,000 people that the World Health Organization recommends, (LOOP, 2019). Adding to the lack of pharmacists is the lack of state control. Haiti has, in the past, experienced the dire consequence of lack of control when it comes to medications. In 1996, contaminated medications22 caused acute kidney failure among children. About 200 children lost their lives and more than 20 became physically and mentally disabled (Ayibopost, 2018; Le Nouvelliste, 2018). The illicit sale of medications by street vendors was facilitated by the combination of lack of pharmacists and absence of state control of the practice.

Vulnerabilities related to public health are also exacerbated by the deplorable sanitary conditions in the country that worsened as a result of the earthquake. Mountains of trash are everywhere. In the public market, street vendors sell their groceries and cooked food near piles of garbage. During a focus group with Sove Fanm (Save the Women), a women's organization, the severity of the problem was raised as a central concern, particularly as it pertained to young poor women in the country. These included problems related to basic hygiene such as washing hands after using the bathroom, a practice that is not always followed in poor communities, because of the absence of the facilities to do so. The inability to adhere to such practices was one of the reasons that explain a postearthquake cholera outbreak, which caused more than 8,700 deaths (Passport Health, 2015).

22 The medications used a chemical named diethylene glycol, which when contaminated is known to cause severe kidney damage. The medications were distributed by the PHARVAL SA, a pharmaceutical company in Haiti. 
Also, Haiti has the second-highest rate of HIV-prevalence in the world for any country outside of Africa (Hintzen, 2019; UK Department for International Development; Global Fund to Fight AIDS, TB, and Malaria; Pan American Health Organization; UNAIDS Secretariat; The World Bank, 2005). This is explained by the combined effects of extreme poverty, poor access to healthcare, and structural vulnerabilities stemming from ineffective government that make Haiti's population extremely vulnerable to epidemics.

These vulnerabilities related to inadequacies of the healthcare system that were exacerbated by the earthquake provide examples of the problem of state incapacity and reliance on NGOs. NGOs cater primarily to basic healing and ignore the fundamental conditions to ensure resilience, prevention, and robust recovery through a vibrant public health system. The lack of capacities and the incapabilities of the state and the absence of a state presence at the local level has led to practices that increase risk, vulnerability, and precarity. NGOs may not be able to address the situation in ways that can produce sustainable outcomes, nor is it their mission. Therefore, the solution resides in a dynamic and effective collaboration between NGO and the local governments or local organizations. The example of Canaan demonstrates the increased vulnerabilities produced by migration and the failure of NGO intervention in the absence of local government and local organizations.

\section{Summary}

In this chapter I argued that the goals established, and the commitments made at the International Donors Conference have not been realized ten years after the earthquake. One 
of the examples of the unrealized goals and promises that I mentioned relates to the major government buildings that have yet to be repaired or nor rebuilt. As a result of the failure of the intervention to realize development goals, new vulnerabilities have been created and existing vulnerabilities exacerbated. The sale of medications on the streets of Port-auPrince and the construction of Canaan are examples of such failure. This failure can be explained by the state incapacities but largely by ineffectiveness of the disaster intervention. The solution is NGO collaboration with local governments and organizations as an alternative. Particularly, the example of Canaan demonstrates the increased vulnerabilities produced by migration and the failure of NGO intervention in the absence of local government and local organizations. 


\section{Chapter Seven: Unending Relief and Increased Vulnerabilities}

Nations can escape the forms of disjuncture that create precarity and vulnerability if they invest in genuine development. The rationale of my dissertation is, therefore, for disaster aid to reduce vulnerability and create resilience, it needs to pursue development goals. Generally, disaster intervention focuses its efforts on three types of activities: relief, rehabilitation, and reconstruction (Christoplos, 2006; Dube, 2019; Mosel and Levine, 2014; Ramet, 2012). The first type, relief efforts also called emergency aid, aims to save lives, prevent a worsening of the impact of the disaster, and bring aid to victims (Riddell, 2008). The second type, rehabilitation, focuses on helping people and restoring conditions of habitability and is often seen as a bridge between relief and development (BauchananSmith and Maxwell, 1994; Dube, 2019; Ramet, 2012). It allows people to regain their functionality and rebuild their lives. As such, it aims to reorganize administrative, sanitary, and governmental structures (Mosel and Levine, 2014). And the third type engages the reconstruction process. The goal of reconstruction is to rebuild the physical infrastructure. This phase can open up opportunities for corrective measures by building more resilient and sustainable infrastructures (Dube, 2019).

Haiti's post-disaster response prioritized relief and paid less attention to rehabilitation and reconstruction. Things have still not returned to normal, as I have demonstrated in Chapter Five. The intervention has, therefore, failed. There are three reasons for this failure: 1) inadequate efforts to increase the capacities of people and reduce their vulnerability, 2) lack of collaboration between the NGOs and local governments, and 3) state inefficiency. 


\section{Inadequate efforts to Increase Capacities and Reduce Vulnerabilities}

Based on the institutional ethnography of three NGOs and the in-depth, semi-structured interviews that I conducted, it becomes evident that the explanation for the failure of recovery efforts is that Haiti's disaster response efforts were not designed to undertake sustainable interventions that could have long-term outcomes. This particularly relates to the way funding was allocated for the intervention. Much of the funding was allocated for relief activities. I raised in Chapter Two, the possibility of linking relief to development. Such possibilities were not thoroughly considered by NGOs because they think that longterm outcomes are outside their mandate.

I conducted institutional ethnographies of three NGOs (see Table 7.1) engaged in relief work in Haiti to assess the reasons why recovery efforts failed and to examine practices that offer possibilities for sustainable interventions.

Table 7.1: List of NGOs, Field Intervention, and Philosophy

\begin{tabular}{|c|c|c|c|c|}
\hline NGOs & Types & $\begin{array}{l}\text { Field of } \\
\text { Intervention }\end{array}$ & Location & Mission/Philosophy \\
\hline $\begin{array}{l}\text { Cooperation- } \\
\text { zione } \\
\text { Internationale } \\
(\mathrm{COOPI})\end{array}$ & $\begin{array}{l}\text { Non- } \\
\text { Religious }\end{array}$ & $\begin{array}{l}\text { Infrastructure, } \\
\text { Disaster } \\
\text { Prevention, } \\
\text { and } \\
\text { Preparedness }\end{array}$ & $\begin{array}{l}\text { Tabarre, } \\
\text { Cite } \\
\text { Soleil, } \\
\text { Port-au- } \\
\text { Prince }\end{array}$ & $\begin{array}{l}\text { Supporting } \\
\text { communities for } \\
\text { recovery and long- } \\
\text { lasting development }\end{array}$ \\
\hline $\begin{array}{l}\text { Compassion } \\
\text { International }\end{array}$ & Religious & $\begin{array}{l}\text { Education, } \\
\text { Micro-finance, }\end{array}$ & $\begin{array}{l}\text { Carrefour/ } \\
\text { Delmas, } \\
\text { Port-au- } \\
\text { Prince, Cite } \\
\text { Soleil }\end{array}$ & $\begin{array}{l}\text { Release children } \\
\text { from poverty }\end{array}$ \\
\hline
\end{tabular}




\begin{tabular}{|l|l|l|l|l|}
\hline GOAL & Non- & $\begin{array}{l}\text { Development, } \\
\text { Environment, } \\
\text { Religious }\end{array}$ & $\begin{array}{l}\text { Port-au- } \\
\text { Prince }\end{array}$ & $\begin{array}{l}\text { To create safe and } \\
\text { resilient } \\
\text { communities. }\end{array}$ \\
& & & $\begin{array}{l}\text { Bringing lasting } \\
\text { change to improve } \\
\text { the lives of Haitians }\end{array}$ \\
\hline
\end{tabular}

Mr. Bonamy, a former UN consultant in Haiti who has been working on relief interventions in many countries in Africa, and who was an NGO consultant in Haiti at the time of my fieldwork, explained in an interview with me the difficulty inherent in incorporating efforts at sustainability into relief:

If I am the director of an emergency aid non-governmental organization, my mandate is to respond to an emergency. An emergency, what is it for an emergency organization? It's that you have a baseline. Take, for example, Cite Soleil! We have a baseline made up of social, health, economic, and security data, etc. And we know about the normal situation based on statistical data. Me as an emergency NGO, I will not intervene on a problem that is a global issue, political economy, social, that is from the realm of substantive sustainable intervention ... On the other hand, if there is an earthquake, all the data are collapse, here I am going to intervene. I will intervene because it is my mandate. I am responding to an emergency because this baseline has been broken. There is a break and this rupture puts people's lives in danger. And here I intervene. I intervene so that there are fewer possible deaths, less possible injuries, and to try to place back the line that was fractured. At the level of a long-term intervention, it is not my level as an emergency organization that this baseline that we are trying to upgrade, it's not good as an emergency NGOs 
to do it. I do not have the capacity. I do not have the resources, I cannot afford it, and it's not my mandate. 23

Mr. Bonamy is referring to a reality built into the mandate of a relief organization and relief efforts - the fact that sustainable interventions are not built into their mandate. As emergency relief NGOs, their mandates are to save lives, feed the hungry, provide temporary shelters, and the like. Mr. Bonamy compared the situation of Haiti in the aftermath of the earthquake to an individual who had a heart attack. Emergency assistance was called. The goal of the emergency team is, at this point, only to save the life of the patient. If the team arrives and does just that, their mission is over. However, the reality is that the team also arrives in an ambulance. Once the condition is stabilized, or while the EMT is trying to stabilize the patient, the ambulance takes the patient to the hospital, and the team that specializes in rehabilitation and the cure takes over. Mr. Bonamy says:

In case of a catastrophe, the impact of the response is immediate. I take the example of a medical NGO; you have a patient who is walking from home to go to work. And suddenly she/ he has a cardiovascular attack. The emergency response is that you have a team that comes in, takes the issue in charge, revives the patient, stabilizes him or her, and takes the patient to the hospital. Once the patient is revived, the emergency work is over, and you have saved that life. But then there is much work to do. What are the causes of this cardiac arrest? And it is not the emergency team that will work on it. They do not have the capacity, the memory, or the knowledge to investigate the cause of this cardiovascular event. You will

23 Interview with a former UN consultant in Haiti. 
have in front of you a professional in cardiology who will have to do analysis, who will treat the problem and increase the resilience of his patient, to ask him to follow a treatment that will be identifiable, by analyzing what the person has suffered in his heart, if it is necessary to schedule an operation in a year or two, etc. And, one is in the increase in the resilience of the patient. And this is done over a year or two years. While the emergency response is done in an hour or two.

The point Mr. Bonamy is making here is that emergency medical response personnel do not have the capabilities and capacities needed for rehabilitation. It is the work of another team of specialists who engage in rehabilitation and long-term outcomes.

The reality is that many relief organizations continued to work in Haiti, years after the earthquake. Some of them were still there ten years after the earthquake. This explains, partly, Haiti's failure to recover, given the almost exclusive focus on relief. This exclusive focus on relief was exemplified in the long-term practices of GOAL24, an international humanitarian NGO founded in Ireland over 40 years ago. GOAL launched an emergency intervention in Haiti immediately following the earthquake that was still ongoing at the time that I conducted my study, ten years later. One of GOAL's high-ranking officers explained the situation in this way:

Moreover, there was the whole issue of emergency projects that were not intended to bring lasting results but, first of all, to immediately bring help. Mainly, I think all the emergency interventions that we still see five years after, you should know

${ }_{24}$ GOAL is not an acronym. It is the official name of the Irish NGO. Organization's website: https://www.goalglobal.org/ 
that these programs were not planned to last five (5) years, but because of the stagnation of the situation those things remain 25.

The need for disaster relief will continue to persist because people's lives and well-being continue to be at risk. In addition, the recurrence of disasters is so pervasive that it has become the standardized practice for NGOs to be perpetually moving from one location to another in order to replicate their efforts of disaster relief. For example, during my fieldwork in Haiti, GOAL was about to move to Jérémie, the Southwest side of the country, to implement the same project that they had implemented in Port-au-Prince. Jérémie was severely hit by hurricane Matthew (Reliefweb, 2016). This hurricane struck the South and Southwest side of the country in the Fall of 2016, leaving more than 1.4 million people in need of humanitarian assistance and damaged around 200,000 homes (Reliefweb, 2016).

Some emergency agencies that were in Haiti as a result of the earthquake left because they did not see their mission in terms of the long-haul, nor was it to build resilience. What is indicated here is a clear need for NGOs and other types of interventions to support programs and projects for substantive sustainable development. Without these efforts, there would be a perpetual need for disaster relief in the face of the common recurrence of catastrophic events in Haiti.

I am arguing here for development -- for a better approach to build efforts to reduce vulnerability and increase resilience. This approach requires two things: 1) for the increase of funding for development agencies, and 2) for resilience to be integrated into programs and projects related to disaster intervention.

25 Interview with the head of Mission of GOAL in Haiti. 


\section{Increase funding for Development Agencies}

The question of funding remained a recurrent theme in the interviews and focus groups that I conducted. Even though there was a significant influx of emergency NGOs in the wake of the earthquake, there was little money allocated to efforts aimed at sustainable intervention. Mrs. Désauguste, CLIO’s resilience committee chair, put it in this way:

Many NGOs are in the humanitarian response. Because for a country like Haiti, it is difficult to have an emergency and then not to come. This will discredit you as an organization in front of the population, because you are supposed to help. So, as you come in for the response, you therefore automatically enter the humanitarian response. 26

Notwithstanding the fact of intervention, it is the structure of the response that contributes to the persistence of the crisis leading to the need for additional relief efforts. There are two explanations for the way in which the response is organized. Firstly, donors fund shortterm projects, which makes it difficult for agencies to implement projects with possible long-term outcomes. Mr. Bonamy explains it:

Concerning the fund that is allocated to emergency organizations, the major emergency donors, from my point of view, require a few things impossible to achieve. If you take the main emergency donors like ECHO from the European Union, you notice that their funding for the emergency response is in very short

\footnotetext{
26 Interview with a CLIO’s official.
} 
cycles. In general, most contracts that are signed between these emergency donors and emergency NGOs are contracts of twelve months to eighteen months 27.

Even for development NGOs who receive funding for more sustainable projects, a cycle of 12-18 months comes with significant problems. Mr. Bonamy continues: It is extremely difficult, if not impossible, to develop global resilience capacities after the earthquake in a capital like Port-au-Prince in eighteen months. It is an impossible mission. I could give you two or three examples of European NGOs that have benefited from the funds to rebuild, improve homes, so they resist cyclones, that was in the Nippes. And at the end of the twelve-month project, the organization was unable to build the 500 houses for which it received funding. Why? Because it's impossible to do that in twelve months and even in eighteen.

... So, there is also this contradiction, there is a strong demand from all the donors of the global system on the emergency NGOs by telling them you must identify this response that allows you to develop these resilience capacities. Even if the financial resources are there, the mechanisms of these contracts and the donors very often do not give these organizations the time necessary to develop these strategies 28.

NGOs were forced to focus on humanitarian projects because that is where the money was. Even NGOs that work in the area of development were forced to focus particularly on humanitarian projects for which funding was easier to receive. This was the case for the Cooperazione Internazionale (COOPI), an Italian NGO that works both in emergencies and development. According to its website, "COOPI operates in contexts of extreme

27 Interview with a former UN consultant in Haiti.

28 Ibid 
poverty and socio-political or environmental vulnerability implementing the Linking Relief, Rehabilitation and Development (LRRD) approach. This gives COOPI the chance to provide sustainable and long-term responses, ensuring continuity between security, humanitarian aid and development (COOPI Website).

The Head of Mission of COOPI in Haiti at the time of my fieldwork described a project that her organization was working on:

We also work at cite Soleil. Cite Soleil is an extremely vulnerable area (see Figure 7.1). And here, for example, we intervene with cash for work. Cash for work, and the works we were targeting were cleaning the canals. This cleaning of the canals was done with the Municipality. We sat down with the mayors and asked what areas are you targeting that need more cleaning. The mayors and with some other leaders decided 29 that it was Drouillard. The Drouillard project, we started working in the area, we did cash for work, 120 people for 15 days to clean the area. This is really an emergency, an emergency intervention. What happens in these areas is that almost every time there is an hour of rain, even if it is not too heavy, the days after there is a flood in these areas 30.

The Head Mission also added:

\footnotetext{
29 Municipalities in Haiti are managed by a council of three Mayors. The first mayor (the principal mayor) is assisted by two other mayors: second mayor and third mayor).

30 Interview with COOPI's Head of Mission in Haiti
} 
Significant intervention is required. We did a cash for work; it was a punctual action to help out the situation a bit, but I assure you that a week after or a few days after the area will be as it was31.

The point of this is that, even for an NGO whose focus is on sustainability, resources prevent long-term responses leading to a concentration on stopgap short-term measures.

When I asked the Head of Mission why she is not looking to get funding for a more sustainable project, she replied that it was not easy because the United Nations aid funding program often decides their priorities, which may not be for something sustainable. Therefore, there is a need to extend the timeframe for the projects because the need continues beyond the normal funding cycle. Mostly, there is a need to divert money towards more sustainable projects and to development agencies that are capable of building resilience.

31 Ibid 


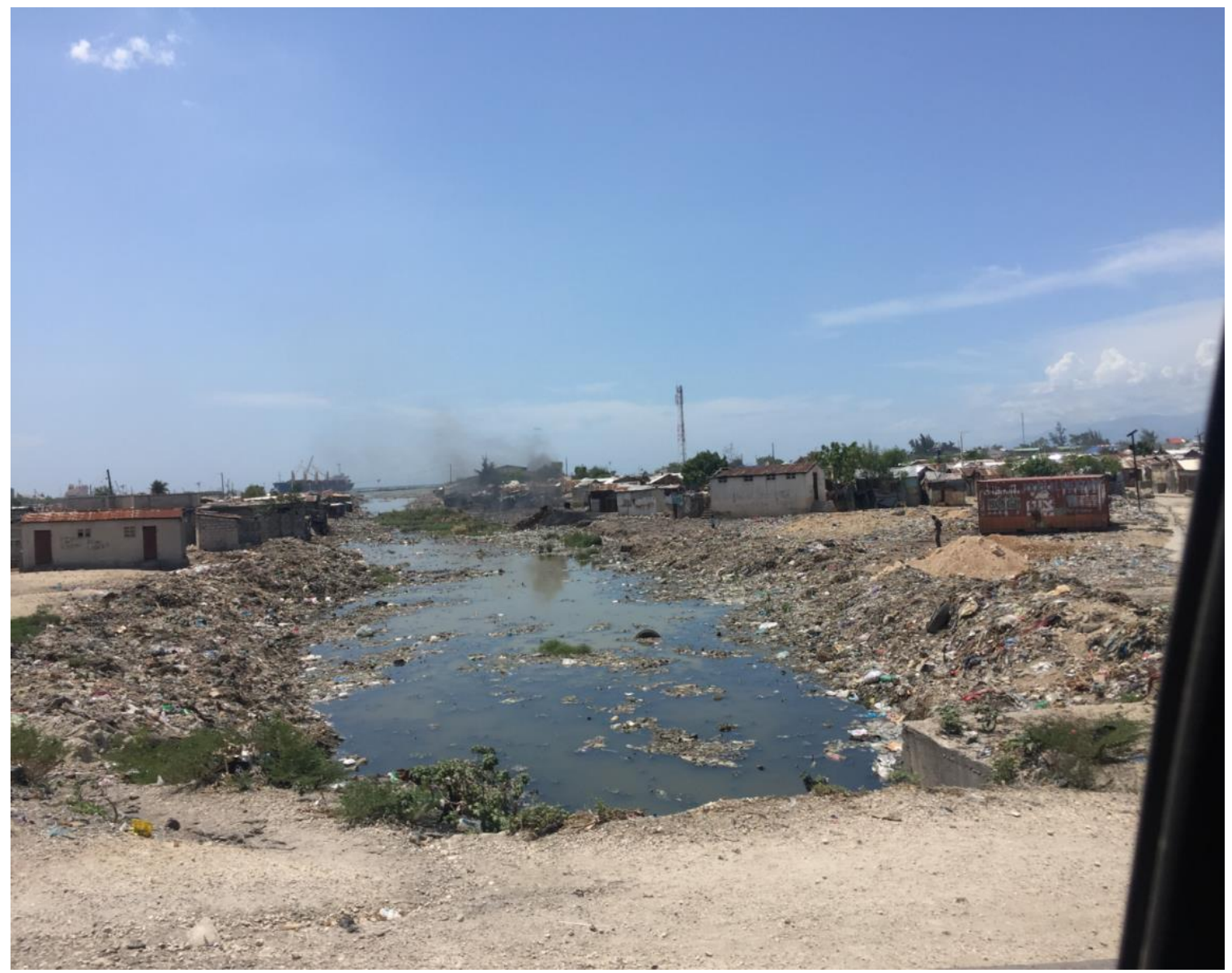

Figure 7.1: Drainage filled with debris and trash near Cité Soleil 32.

\section{Building Resilience into Projects}

In Chapter two, I have argued that resilience allows communities to recover in the wake of a disaster quickly. Resilience can be built when a system can withstand a disaster, or be able to recover rapidly after a disaster has occurred -- for example, building a bridge to repair a road allows the road to return to use immediately after a disaster has occurred.

32 Photo taken by Jean Max Charles during fieldwork In Haiti. 
It is clear that resilience was not built into the post-disaster response efforts in Haiti. There was unanimous agreement among the NGO officials interviewed that disaster intervention did not increase resilience to disasters in Haiti. There are at least two reasons that explain this failure: 1) a lack of collaboration between NGOs and the local governments; and 2) a disjuncture between humanitarian efforts, rehabilitation, and the construction phase.

\section{Lack of Collaboration Between Aid Agencies/NGOs and Local Governments}

International funding agencies have been reluctant to involve local governments and have not supported their efforts to be involved in post-disaster relief. This has been the case even when local officials were approached. This can be explained partly by decisions by funders to bypass national and local authorities because of corruption, inefficiency, and inefficacy, as previously discussed. When they do this, funds are usually allocated to the central government and expended in ways that deny local authorities the capacity to implement sustainable programs and projects.

A mayor that I interviewed during my fieldwork explained some frustration at this level. The mayor reported that there was a series of workshops organized by the European Union (EU) in which the mayors were invited to present projects to help their respective community with the hope that the EU will fund those projects. All the mayors designed their projects and submitted them to the EU. A few weeks later, the EU informed all the mayors that they are no longer dealing with the local governments, but rather the central administration. The current structure seems problematic if it prevents NGOs and multilateral agencies from providing funds directly to local authorities and governments. 
The practice by official funding agencies of excluding the participation of national and local organizations in the post-disaster response goes a far way in explaining its failure. This was pointed out by Mr. Bonamy in our interview:

At the national level, you have capacities within the civil society, local organizations which could very well acquire these capacities for emergency response, but they are not. Then, you have to pose the problem of access to funding that allows the local organizations to develop these capacities. National organizations often have a great deal of difficulty to have access to these funds which can allow them, on the one hand, to prepare and, on the other hand, to respond. They are not very often eligible for funding from emergency donors 33.

National and local agencies are often more effective than international agencies, as I have argued in Chapter Four. Not only do they have a better knowledge of the reality on the ground, but also, they are more cost-effective management. There are problems related to the high costs associated with the payment of international consultants and expatriates to implement a project that can be reduced significantly by the employment of nationals. There are also problems related to unfamiliarity with local policies and official and unofficial practices and arrangements. During the institutional ethnography of GOAL, I observed the implementation of a rebuilding project in Turgeau in a neighborhood in the commune of Port-au-Prince. About USD 2.5 million was spent in the project, but not many houses were repaired or rebuilt. A GOAL's director implicitly expressed his uneasiness with the failure of the project to fully and efficiently realize its stated goals:

33 Interview with a former UN consultant in Haiti 
We were able to work on 80 houses. It is not much in an area that may have 2,500 houses. We were stuck on the issue of land rights. Perhaps $70 \%$ of the area has been declared out of bounds due to land issues. It was difficult. This has limited our interventions from small pockets at the accommodation level. And we made 80 houses which are validated by the engineers, good structure etc.... For these 80 houses it works, on the other hand it costs us a lot of money for 80 houses. I don't know if this is the solution for all our problems 34.

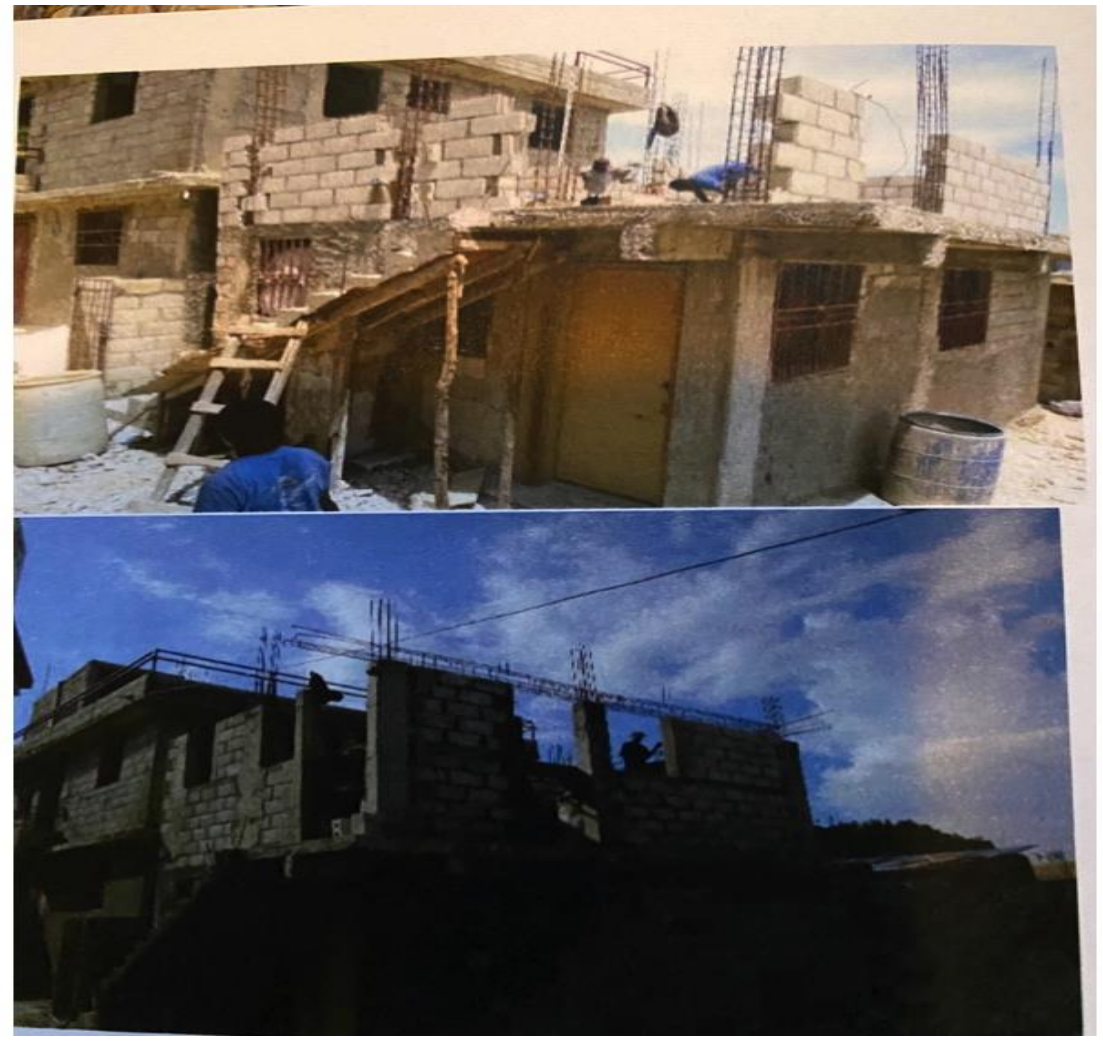

Figure 7.2: Homes built by GOAL in Turgeau, Port-au-Prince 
The issue of the land rights that he mentions is a very complicated one in Haiti. Many homeowners have no land title. While some people build on family land (without any land title), many often build on a piece of land that they rent from a landowner with the possibility for the homeowner to buy in the future if the landowner decides to sell. The law does not fully protect the homeowner against the landowner in case the homeowner is not able to purchase when the landowner decides to sell.

It becomes clear that the poor performance in efforts to implement the project and in the realization of its deliverables is a result of the lack of knowledge of the structural problems as they relate to land issues in Turgeau and the transactional cost of the project. Much of these could have been resolved by the participation of a local NGO familiar with land issues and where costs could have been significantly reduced. More houses would have been repaired or rebuilt.

\section{Relief and Sustainable Development}

In order to do so, sustainable development needs to be incorporated into emergency relief planning. There is a need to implement in disaster relief effort the coordinated sequential incorporation of rehabilitation and reconstruction in order to ensure sustainable recovery and resilience. This can be done through effective collaboration between donors and local institutions but also between international NGOs and local institutions, which encompass local governments, NGOs, and other local stakeholders, and agencies. Ideally, local institutions are more informed of the reality on the ground, the eventual challenges that the response may face, and how to solve those challenges. It also requires aid agencies and international NGOs to build local capacities and strengthen relationships with local 
institutions and organizations by showing a greater capacity to manage. Capacity building can be formed when aid agencies channel money through those organizations and when NGOs work jointly with them. The benefit of such an approach is that real issues will be tackled with fewer external resources, which will result in greater outcomes.

Also significant for rehabilitation and the reconstruction process is to attack the structural conditions that make people vulnerable in the first place. For example, it requires new housing models and styles that can resist an earthquake in the case of Haiti, a proper drainage system capable of mitigating the consequence of a flood, bridges and roads that are easy to make and to rebuild in the advent of a disaster, resilient healthcare based on prevention and costly effective care, and the development of an efficient social management system through a dynamic collaboration between NGOs and local government. Such social management requires agencies to work toward mitigating risks and prevent the next disaster.

I discussed the idea of linking relief with development in Chapter two. As difficult as such a linking may be to put into practice, there is considerable evidence of its feasibility. Fritz Dorvilier, sociologist and professor at Haiti State University, thinks that the two are complementary. He said:

We must reconcile the two. Education is a development factor. If we send a child to school, the child cannot learn if he is hungry, we cannot make this child a development actor tomorrow. He will not be able to graduate. He will drop out of school, or he will learn poorly, he will not be able to participate in development. But if there is an occasional help which provides a school canteen, then the child will be able to learn better in school. At that point we can reconcile humanitarian 
aid and development, we can reconcile the school canteen, the uniform, the shoes, and building a new school for children. So the schools that were degraded, destroyed by the earthquake, if we had humanitarian aid that builds those schools, even if it is occasional aid, it is humanitarian aid, of short duration, but the school, infrastructure will last, education will last for generations, etc. When there is a famine somewhere in the rural area and help is provided, instead of the population of this area to migrate to Port- au- Prince they stay since aid is provided to them. If the population migrates to Port-au-Prince, they will swell the slums, their vulnerability will increase, there will be violence, banditry, and insecurity. But if we provide some help to these people there, they will be able to cross the impasse, the impasse of famine. At that time we will give them food, seeds, and tools. It is humanitarian aid but at the same time, the children are trained, schools are built at the same time, we give them occasional help but at the same time we help to plant, we help them to develop small businesses, to develop skills in different areas. At that time, we reconcile humanitarian aid to development 35.

The political economist, Abnel Désamours, attempted to solve the issue differently. He considered not whether emergency relief and development can be linked, but rather how emergency relief can be provided in other ways to contribute to development.

I believe that the activities listed in the case of emergency interventions, these activities ... we can do humanitarian work at the same time as we do the structural. For example, when using cash for work for sanitation activities, I think that when

35 Interview with a Professor of Sociology at Haiti State University. 
spending huge funds on sanitation, I am not saying that sanitation activities are not important, but if with this money we use it either to facilitate the construction of these irrigation canals, or for the rehabilitation of watersheds to reduce our economic vulnerability if this money is used for this purpose we can reconcile emergency assistance and the long-term. What is the objective? It is to allow individuals to recover their livelihood following a disaster. When they are employed in such activities, they earn a little income, now the whole question is, what are we going to employ them for? Are we going to use them to solve problems that are likely to strengthen the economy, and which are likely to strengthen the productive apparatus, or reduce environmental vulnerability?36

The problem, of course, is that in order for relief to be provided in a way that can produce long-term outcomes, it requires international NGOs and funders to work with local agencies and authorities because of the inefficiencies and incapabilities of the central government to provide effective government oversight and facilitate necessary cooperation between the state and NGOs.

\section{State Inefficiency and Lack of Coordination}

In Chapter Five, I argued that for disaster aid to be effective, in the absence of an effective and efficient state, aid needs to be channeled through local government and organizations. There are strategies that can be pursued at the local level to ensure resilience, such as for NGOs and funders to work with local organizations and local authorities. Regardless of

36 Interview with a Professor of Political economics at Haiti State University. 
whether development NGOs are in charge of the intervention, it would be difficult for such intervention to be successful without the critical involvement and guidance of the state or the local government and authorities. Mr. Bonamy put it this way:

Other donors who are development donors like the European Commission, USAID, these donors have the contractual possibilities much more important in terms of amount and much more important in terms of duration, which can go up to four years, up to five years. And there you can effectively develop strategies that will allow an urban city like Port-au-Prince to develop something with the populations but also with the authorities, with the state. Because we cannot develop systems in an urban area like Port-au-Prince that can improve the resilience of urban populations without the necessary implications of the administrative authorities that manage things. 37

Mr. Bonamy's argument implies that sustainable intervention can be done through effective local administrations. The essential role of the state is to make such cooperation possible. The local administration needs to create the necessary infrastructure and make policies that facilitate the cooperation between local organizations/governments and NGOs38.

With effective cooperation between the local authorities and NGOs, both rehabilitation and reconstruction can occur simultaneously. There are multiple examples of successes resulting from such cooperation. A meaningful example of the successes following a disaster occurred when Typhoon Morakot hit Taiwan in August 2009, causing

37 Interview with a former UN consultant in Haiti

38 Ibid. 
major damages, including a serious landslide. As a result of a dynamic collaboration between NGOs and a capable state, an efficient post-disaster response was implemented. The collaboration allowed the successful task of reconstruction to begin two weeks after the disaster (Chern and Tsung Liu, 2014). Although in the case of Typhoon Morakot's post-disaster intervention, the response was done under the guidance of an effective state, there was a strong presence of the local governments in the management and implementation of the response.

Chern and Liu (2014) report that during the phase of reconstruction, the central government made the policy directives, prepared the budget, provided the land for the reconstruction, and undertook the reconstruction of public places, while the responsibility of the management of the reconstruction and decision on the policies for future maintenance and management was undertaken by the local governments. The NGOs were instructed to build private permanent housing. Under the coordination of the government, they built permanent houses by districts. The government decided on the timeline, the style for the housing reconstruction, and the organization was entrusted with implementing the work by districts.

All the issues with regard to rezoning, land acquisition and compensation, negotiation with landowners were cleared with the government to facilitate the building agencies' work. With such coordination, the rehabilitation and the reconstruction occurred rapidly. In the Tzu Chi Da-ai community, for example, with the coordination of the local government, an agency completed the first phase of a project by building more than 600 hundred houses within six months following the typhoon. 
Chern and Liu (2016) point out that two years after the catastrophic event, about 90 percent of the total required houses were already completed. All the other work of rehabilitation, such as road paving, streetlights, and running water, were implemented mainly by the government immediately after the construction was over. In addition to the government intervention, NGOs assisted in building disaster-resilient bridges, river management, and implementing industrial activities that created long-term employment opportunities for the residents.

Such collaboration was lacking in the post-disaster intervention in Haiti. The incapacities and ineffectual nature of the state prevented any chance at collaboration with NGOs, which is a necessary condition for success. Indeed, since the earthquake, the state has become even more ineffectual and less reliable as a partner. NGOs have resorted to replicating their efforts in response to new disasters. This acts to the detriment of recovery efforts, preventing and forestalling successful rehabilitation.

Another example of how state inefficiency and incapacity reduce NGOs' chances for success relates to the fact that state presence is almost nonexistent in many local communities, even when for the purpose of law enforcement. This has significant negative effects on the ability of NGOs to function. A high-ranking staff member at Compassion International emphasized this point by pointing out the organization's inability to build safer houses. This is because, in the face of the absence of the state, unregulated squatting and building is rampant, and creating serious exposure to risk and safety concerns. These could be resolved at the local level. He expressed his frustration in these terms:

The state is not a state that takes responsibility for enforcing construction norms and standards; there is not a construction plan. If there is something on paper, they 
do not apply it. Because of that, people build anywhere and anyhow. There is no inspection before once starts building, no local authority to tell you if you can build or not. People have built near the ravine, with no water, no road, no norms to follow. Which places the country in a situation of chaos? No matter what state, how it is built, or where it is built. The state does not have such control capacity. Everyone lives and expects anything, anytime, may happen" 39.

The solution here is to provide the capabilities at the local level, to local authorities. NGOs are not opposed to a form of oversight. Instead, they share the idea that in order to function effectively, it is imperative that they collaborate with and be guided by state policy and practice. Perhaps, in an ideal situation, this would be their preference. They are pointing out the problems posed by an ineffectual and inefficient state that is not present. Joseph Provost, the president of a U.S.-based charity that funds college education in Haiti, expressed his frustration by complaining about the lack of state guidance to direct the charity's interventions. There were no officials available who could point them to where the needs are. He complained that as a result, "people come out and do it on their own, and they come down saying we will help do this for you and the Haitians said go ahead, do it". The point is that, in the absence of an effective state presence, NGOs must depend on local participation.

He also expressed his deep frustration with corruption. Small charities (like Provost's Friend of Haiti), who do not have the same name, protection, or notoriety as the 'big NGOs,' find themselves without protection from the pervasive demands for bribery or

\footnotetext{
39 Interview with one of the Compassion International project directors.
} 
corrupt demands from officials. As an example, they are often forced to pay money under the table at customs to get their stuff, supplies, or aid packages that they bring for the country. This is another impediment.

The issues of incapacity, inefficiency, and corruption at all levels of government come with severe consequences relating to decisions for NGOs to operate in the country. In the absence of an effective and efficient state presence, some NGOs are finding ways to effectively and efficiently engage in good practices and projects with long-term positive outcomes that some NGOs are implementing. It is important to share a few examples of these as well.

\section{Between Frustration and Hope}

Despite frustrations that they face, NGOs are providing effective services in many areas, and this is providing hope for the future. Many are successfully implementing and running projects capable of producing long-term positive outcomes and increasing people's capabilities and resilience. One example is a school rebuilding project for at least thirty 
schools that were damaged by the earthquake that is funded by the Compassion International NGO.

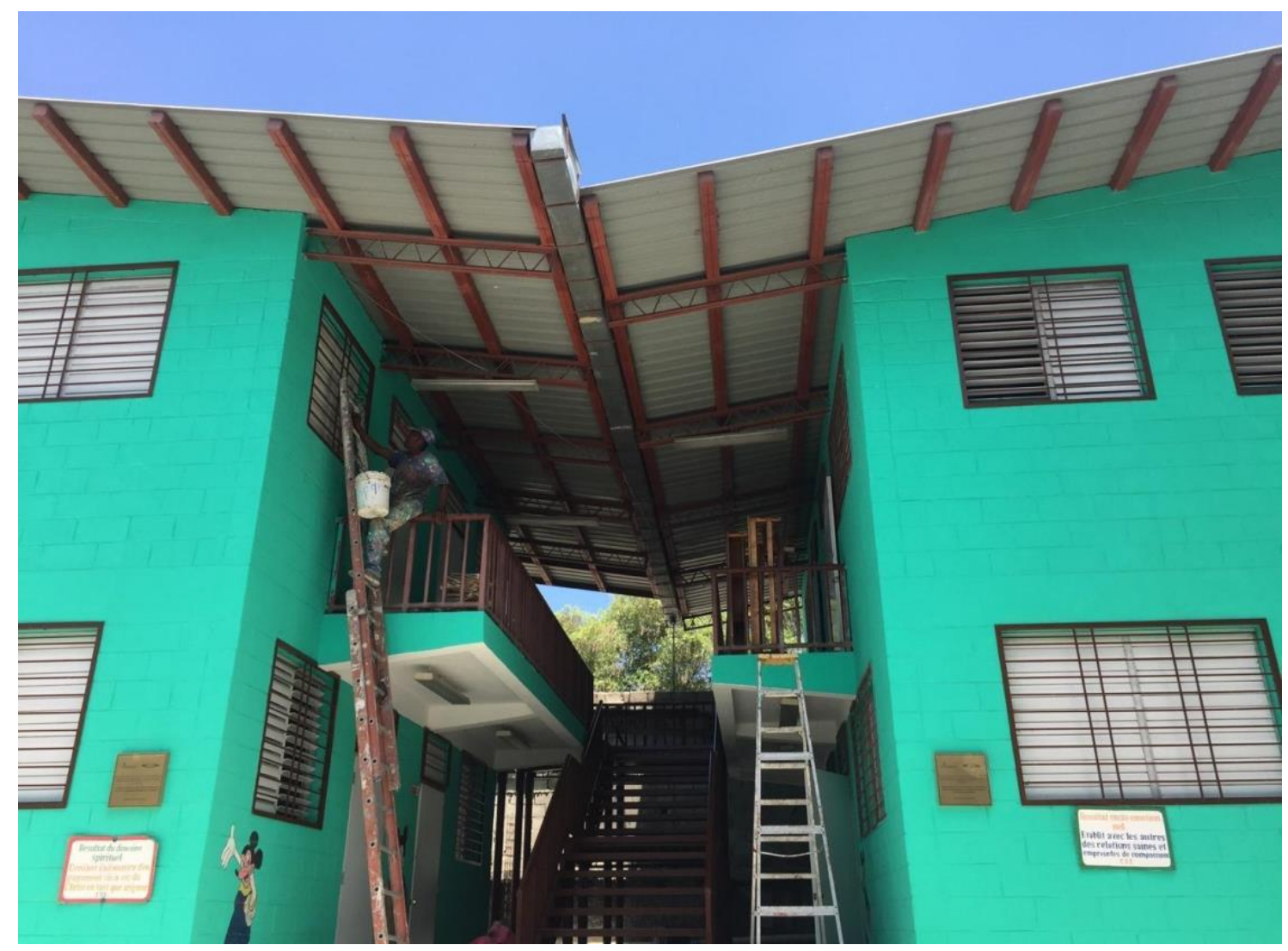

Figure 7.3: School of Eglise Baptiste de Salem40.

The decision was made, from the start to build school structures in ways that satisfy seismic standards and to be hurricane and cyclone resistant (See Figure 7.3). The structures can also be used as shelters in case of a potentially disastrous natural event. While not many

40 Earthquake and hurricane resistant structure built by Compassion International after the earthquake. Photo taken during my fieldwork in Haiti. According to a church leader I talked with, the structure is designated by the Haitian government as potential public shelter in case of a natural event. And it seems to be the case for all the other school structures built by Compassion International after the earthquake. 
schools have been rebuilt, this project is an example of good practices that can be replicated elsewhere.

Two other projects that I researched during my fieldwork provide similar examples of success and good practices that are sustainable by building the capacities of the community stakeholders. One that was previously mentioned was designed by Compassion International as an income-generating strategy, and the other as an emergency and disaster preparedness project implemented by the COOPI. These two case studies are presented below.

\section{Case Study One: Income Generation Activities (IGA)}

This program was designed to help beneficiaries stakeholders either to open small businesses or to expand a previous business by providing low-interest loans at twelve percent annual interest rates, "which was far better than the other IGA organizations where loan interest rates can reach as 40 percent". The program started in 2010 and ended in 2014. Initially, the program intended to provide over one million dollars in loans to a total of one thousand individuals. As requirements to apply for the program, applicants needed to take a basic business planning training offered by Compassion International and submit a business plan with the loan application. Approved applicants received the loan. The program trained approximately 1,250 individuals, provided more than 1.2 million USD, facilitated the creation of 453 businesses, and created possibly thousands of new jobs. The program stopped providing new loans in early 2014. 


\section{Discussion}

The Compassion International Income Generating Activities program directly attacks the root causes of people's material and financial vulnerabilities, which -- among other things -- are related to income depletion, unemployment, and lack of access to financial services. It resolves these problems by increasing its recipients' capacities by providing financial training, relatively long-term financial stability to recipients and their households, and creating jobs. Five years after the program ended, many of those small businesses still existed.

I interviewed the manager of the project. He praised the success of the program and pointed to its practice of working with the recipients, giving them advice on how to grow their business, and empowering women and young people. Many of the beneficiaries were young individuals.

So, I thought it was important for me to meet with some beneficiaries of the program and visit them in my efforts to evaluate the success of the program. I met with five beneficiaries who shared their assessment with me. In Figure 7.4, I present a show store that I visited. This business was created through a grant from the program. One loan recipient, for example, was able to use the earnings from his resuscitated business to rebuild his house, which had been damaged in the earthquake, through the program. After the earthquake, he lost his business, a tailor shop. With the loan from Compassion International, he was able to reopen his shop and later on to rebuild his house. I visited the shop. During our conversation, he shared with me that without this money, he would not 
have been able to get back on his feet. He wished that a program like this would continue so more people could benefit from it.

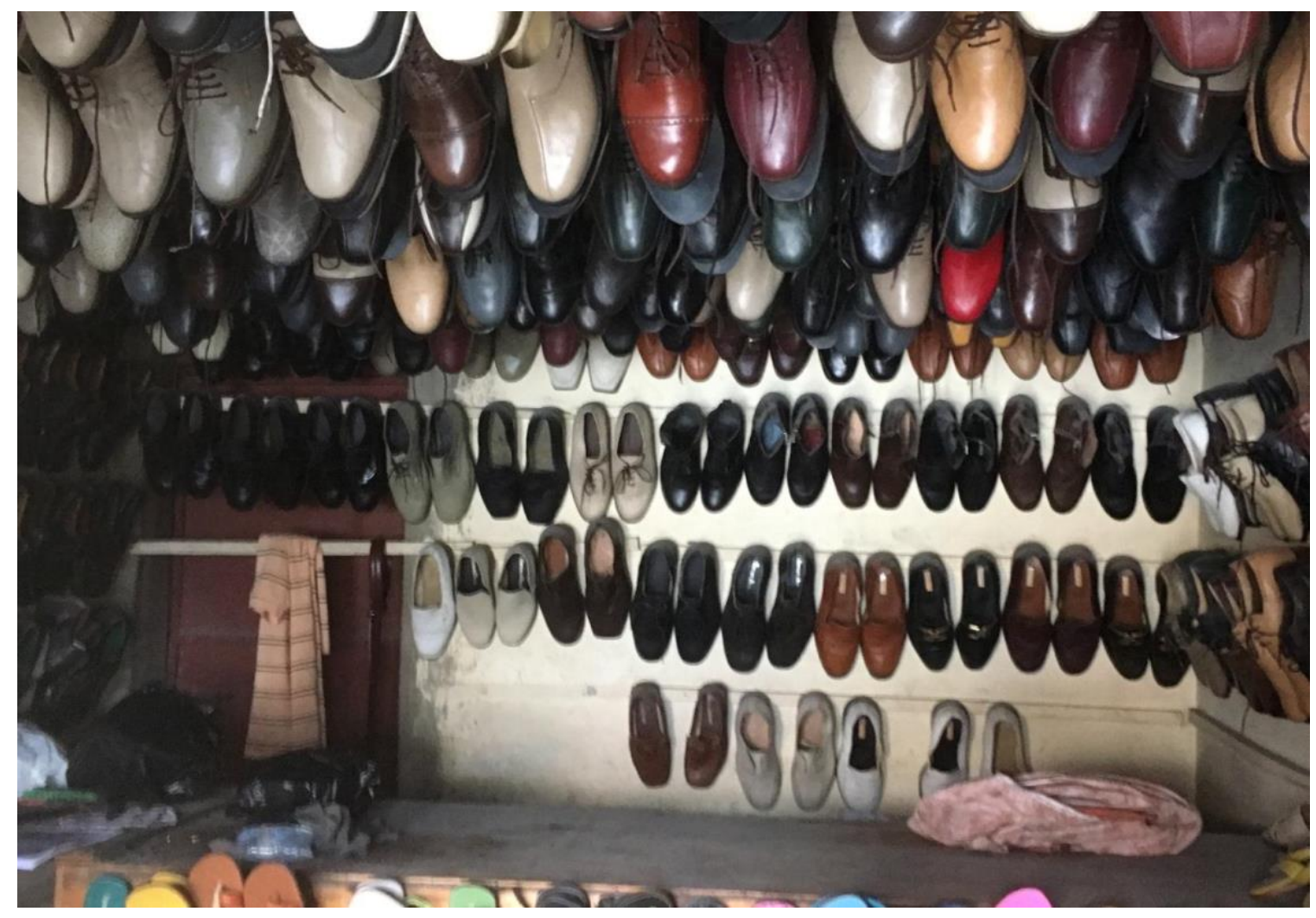

Figure 7.4: Shoe Shop of a Compassion International IGA program beneficiary.

The program was relatively successful despite facing many fundamental problems, particularly such as the management of the portfolio and accounting systems. The problems are largely because the organization had no history and background in this type of activity, nor in microfinance and did not have an existing organizational infrastructure to deliver these services. These problems were particularly evident when the program was first implemented.

In the wake of Hurricane Matthew in 2016, the program was reproduced in Les Cayes, the Southern part of the country, which was devastated by the hurricane. In the 
process, these problems were largely overcome by the time the project was successfully reproduced in Les Cayes.

\section{Case Study Two: Disaster Prevention and Preparedness}

Project: Enhancing physical and social capital at the neighborhood level for disaster preparedness, emergency reaction capacities, and preventive territorial management.

The objective of this project was to reduce the impact of disasters by improving collective infrastructures through small-scale mitigation works for Disaster Reduction Risks (DRR). The project was implemented in 2018 in Tabarre and Cité Soleil, neighborhoods of the greater Port-au-Prince that used to be part of the municipality of Delmas. In Cité Soleil, the project consisted of cleaning the drainage canals. In Tabarre, the project involved constructing walking bridges that linked neighborhoods that were inaccessible when it rains, "improving disaster preparedness response among the most vulnerable through disaster drills" (COOPI Project Report) and strengthening local government DRR capacity. The projects built more than twelve walking bridges and distributed emergency kits to many families. With the collaboration of the mayors and the municipality leaders, they established a disaster department in the municipality of Tabarre.

\section{Discussion}

As I have indicated in an earlier reference to this project, the lack of funding severely affected the successful implementation of one aspect of the project, forcing the substitution of the cleaning of the drainage canal system in Cité Soleil for the building of a new one. Where the project succeeded was in the construction of bridges, which aimed "at mitigating 
the population exposure to risks, by addressing difficulties in mobility, lack of knowledge and capacities of communities, public and private local actors on how to mitigate and respond to a natural disasters (COOPI Website) particularly, the bridges were built to facilitate the neighboring population to cross from one community to the next, which was difficult when it is raining and causes serious risk exposures.

More significant, however, was the organizational structure of the project rather than its content. First, the project involved the community in every aspect of its implementation. It utilized a grassroots strategy by working within the community, helping stakeholders to organize themselves and created a structure that had the potential to mitigate damages in case of an unfortunate event.

Secondly, the project developed a dynamic collaboration with the local government. The administrative structure for disaster prevention and mitigation is poorly organized in Haiti, especially at the municipality level. The chief administrator, with responsibility in the municipality for civil protection, is the mayor. COOPI, through this project, created a dynamic relationship with the commune's administrative leadership by providing them with the tools and resources to create a disaster department in the city, and by helping them to create a budget. The department undertook the task of working with the NGO in efforts to mitigate risks and intervene in the case of a catastrophic event. In my interview with Valentina, the country director of COOPI at the time of my fieldwork, she stressed this point: 
I say that mayors need to get involved in the process. The more the mayors get involved, the more positive the response, the stronger the civil perception, the structure, and so on. The less the mayors get involved the less it is structured.41

Thirdly, the project mobilized and empowered women in the community. These women formed an organization called the Regroupment des Femmes Professionelles en Construction (RFPCH) (Group of Professional Women in Construction). They were mobilized to participate in the construction of the bridges in Tabarre. After constructing the bridges, a committee was formed to ensure bridge maintenance. The committee integrated both men and women. Finally, the bridges were easy to repair and replace. In case of potential disaster, the community has the training to repair or replace damaged bridges without soliciting any outside help.

Working with local administration is not without challenges. However, I believe that collaboration between the local government and NGOs creates better opportunities to implement sustainable projects. The COOPI intervention in Tabarre, although modest in terms of funding, provides a good example of a replicable project.

\section{Summary}

In this chapter, I linked the failure of the intervention to the lack of capabilities of centralized government, state corruption, and the relative absence of state presence at the local level. This has resulted in conditions on which donors fund NGOs and the manner in which monies have been allocated that have produced an inherent inability of NGOs to

41 Interview with COOPI's Head of Mission in Haiti 
produce long-term positive outcomes. I used a Taiwan example of disaster management in the wake of the Morakot Typhoon to demonstrate the importance of state guidance and local government involvement in disaster management. While the management of the Morakot Typhoon was done through an effective and capable state, it, however, provided an example of what was needed for a successful rehabilitation. Then, I discussed what was lacking in the case of Haiti post-disaster management and the problems NGOs faced in their efforts. After a discussion of the problems. I provide two examples of effective practices that could be replicated through case studies of two projects implemented by two different NGOs. 


\section{Conclusion}

The primary argument of this dissertation is that disasters occur as a result of the absence of policies and practices of sustainable development that reduce vulnerabilities and build resilience. In the previous chapters, I outlined the research objectives and presented and analyzed my research findings. In Chapter one, I laid out the research problem; I described the research methods and designs. In Chapter two, I addressed the conceptual and theoretical framework of the research. Three main areas of focus, which formed the backbone of my study, and which developed my conceptual and analytical framework,

were: disaster aid/relief, NGOs, and development. Before I addressed the question of disaster aid, I established my theoretical perspective on disasters, which is grounded in a neo-Marxist political economy approach. This perspective that draws heavily on the examination of disasters in the Third World views as epiphenomena produced out of broader structural, social, economic, and political conditions (Blaikie, 1994; Blaikie et al. 1994; Cannon, 1994; Handyman \& Handyman; Hewitt, 1983; 1997; Hilhorst, 2004; Hilhorst \& Bankoff, 2004; 2006; Lavell, 1994; Oliver-Smith, 2003).

Also, in Chapter two, I explored the rise of NGOs as a powerful economic force through a historical analysis. This rise coincides with the development of neoliberalism. I argued that dramatic increases in poverty in the Global South were directly tied to the effects of neoliberal policies and practices spread throughout the Third World. The rise in NGOs is explained by the failure of both the market as well as central and local governments to cater to the generalized needs of the population. I examined this failure from the perspective of the scholarly critiques of economic development. I employed Amartya Sen's perspective that equates development to freedom. In this regard, I added 
Hintzen's perspective that, while agreeing with Sen's argument, proposed that such freedom can be realized only under conditions of effective democracy and good governance. I combined these approaches with Anderson and Woodrow's understanding of development as the process by which vulnerabilities are reduced and capacities increased (Anderson \& Woodrow, 1998). It is this latter approach that primarily informs my dissertation.

In Chapter three, I provided a critical analysis of the application of neoliberalism in Haiti and its social and economic implications. Haiti's reliance on NGOs is mainly a consequence of the implementation of neoliberal policies during the 1980s and 1990s. I demonstrated that these policies contributed to the weakening of the state -- the condition that led to an influx of NGOs in the country.

In Chapter four, I looked at the social, economic, and political conditions of Haiti. The country has been described as weak and inefficient as a result of its failure to implement policies for effective development. This has led to intense vulnerabilities among its population. I also attempt to understand "the case of Haiti" as a country with prolonged and recurrent political crises. Through the lens of Trouillot's perspective that the state has acted against the interests of the nation, I argued that the essential problem of Haiti is that the state is destroying the nation. I articulate how this conflict between state and the nation has taken form in the decades preceding the earthquake.

In Chapter five, I laid out the intensity of the commitments that were made by the international community to rebuild and develop the country. I argued that the commitments expressed were not realized on the ground. Billions of dollars were channeled through 
NGOs for disaster relief. However, the population remains even more vulnerable than before the earthquake.

Chapter six focused on new vulnerabilities that have been created as a consequence of the incapacity of the state and its reliance on NGOs. It supports a claim made in Chapter Two that even well-intentioned relief efforts may intensify preexisting vulnerabilities and introduce new ones. In the chapter, I demonstrated the goals that were set by the International Donors' Conference had not been materialized in the rebuilding of Haiti; I pictured some major government buildings that have yet to be repaired or rebuilt, which can serve as an indicator of unrealized commitments. I also referred to the system and practice of public health delivery, particularly in Port-au-Prince and the construction of a new slum in Port-au-Prince as examples of exacerbated vulnerabilities in the postearthquake period.

Chapter Seven highlights the fact that relief efforts have continued in a process that I termed "unending relief." Then, I argued that for relief efforts to be successful, NGOs must incorporate development goals into aid delivery and intervention. The best way to do so is for NGOs to collaborate with local governments and organizations efficiently. I conclude the chapter with two case studies of NGO projects that underline positive practices and approaches.

My research informs broad debates about NGOs' capabilities to provide successful disaster relief. The case of Haiti raises doubt about the capacities of NGOs to conduct massive relief efforts in the wake of a disaster. My understanding is that, while they have occasionally succeeded in this regard, they are incapable of catering to the task of rehabilitation and reconstruction. These problems are exacerbated under conditions that 
characterize a weak state such as Haiti, particularly given the dependence of the state on NGOs to cater to the well-being and fundamental needs of the population.

When considering the political infrastructure of international aid that favors channeling money through NGOs, I argue that for NGOs to produce positive and long-term outcomes, they need to provide aid in a manner that can build resilience to future disasters. In this context, building disaster-resilient communities have become a centerpiece of my argument. I also argue that this should be a central part of development goals. Resilience should be built into the efforts of NGOs if they aim to deliver aid and aid relief following a disaster successfully.

The research findings allow me to critically analyze the extent to which disaster resilience was built into the post-quake NGO-provided relief in Haiti. The findings show that the Haitian population has become more vulnerable than before and, consequently, less resilient because of the failure to build resilience into their disaster intervention.

A fundamental contribution to this research is that it proposes a collective strategy between NGOs and local governments to ensure better delivery of disaster aid. This is a call for devolution, a process where the local government takes the direction and ownership of their own development. Devolution is a matter of public policy. It requires the central government to concede more responsibility to the local government to be able to control their development, directly negotiate with NGOs, and collaboratively implement programs and projects as they relate to their own community needs and development goals. The case study of COOPI in Chapter Six offers a good example of how a dynamic collaboration between the NGOs and the local government can bring about positive outcomes. 
Another important finding of my dissertation relates to community development. The study suggests community development as the best way to build resilient communities. Community development encompasses appropriate municipal infrastructure such as trash pick-up, road clearance, road construction, public housing, environmental policy, work and credit access, development of risk reduction and disaster awareness, creation of a robust public health care system, and the like. The population can respond to disasters through community development to mitigate risks throughout the community. My dissertation also includes the indicators of resilience, which is mentioned in Chapter Two. Community development may reduce vulnerabilities and increase community resilience to disasters. In this way, the population would benefit considerably when NGOs articulate their interventions toward community improvement.

I advise against overgeneralizing the conclusion of this research to include developed countries. In developed countries, the states have the capacity to intervene more efficiently in the wake of a disaster. In addition, in developed countries, households share risks through private insurance markets, which are willing to take risks associated with disasters. They also share risks through government-run disaster assistance programs, which often help individuals and households affected by disasters (Dore \& Etkin, 2003). Besides, they usually have savings and safety nets that allow them to build even stronger capacities for recovery in the wake of a disaster. However, the results of this research may be applied to any developing country that relies on NGOs for assistance following a calamity. 


\section{References Cited}

Addison, T. (2000). 'Aid Conflict,' in Tarp (ed). Pp. 392-408.

Allen, Katrina (2003). Vulnerability Reduction and Community-based Approach: A Phillipines Study In Pelling Mark (2003). Natural Disasters and Development in a Globalizing World. Routledge.

ALNA (2006). Evaluating Humanitarian Action Using the OECD-DAC Criteria: An ALNAP Guide for Humanitarian Agencies. Overseas Development Institute, London.

ALNAP (2010). Haiti Earthquake Response: Country Analysis.

Ahmed, S. \& Potter David M. (2006). NGOs in International Politics. Kumarian Press.

Anderson, M. (1995). Vulnerability to disaster and sustainable Development: A general Framework for Assessing Vulnerability, in C. Munasinghe (ed) Disaster Prevention for Sustainable Development. World Bank, Washington, DC.

Anderson, M. \& Woodrow, P. (1999). Rising from the Ashes: Development Strategies in Times of Disasters. Westview Press London.

Anderson, M. B. (1996). Do No Harm: Supporting Local Capacities for Peace Through Aid, Cambridge: Collaborative Effort for Development Action.

Arsht, Adrienne (2014). Urbanization in Latin America. Atlantic Council.

Arthur, Charles (2002). In Focus Haiti: A Guide to the People, Politics and Culture. Latin America Bureau. Research and Action.

Bellegarde-Smith et. al (2015). Haiti and Its Occupation by the United States in 1915: Antecedents and Outcomes. Journal of Haitian Studies. Vol. 21, No. 2, Special Issue on the US Occupation of Haiti, 1915-1934, pp. 10-43.

Bankoff, Greg ( (2008). The Historical Geography of Disaster: Vulnerability and Local Knowledge in Bankoff, Greg, Frerks George, and Hilhorst, Dorothea (2008). Mapping Vulnerability: Disasters, Development, and People. Earthscan.

Black, A. \& Evans (1999). Flood Damage in UK: New Insights for Insurance Industry. Dundee: University of Dundee Press.

Blaikie, P.; Cannon T.; Davis, I. and Wisner, B. (1994). At Risk: Natural Hazards, People's Vulnerability, and Disaster. Second ed. Routledge, London and New York. 
Bolt, B. A. (1978). Earthquake: A Primer. San Francisco. W.H. Freeman.

Breslin, Paul. (2008). The First Epic of the New World: How Shall it Be Written. Pp 223249, In Tree of Liberty: Cultural Legacies of the Haitian Revolution in the Atlantic World. Ed. Garraway Doris L. University of Virginia Press.

Bradshaw, Sarah (2014). Engendering Development and Disasters. Disasters, 30(1): 1938, Overseas Development Institute.

Bradshaw, S. and M. Fordham (2013) Women and Girls in Disasters. Report Produced for the Department for International Development, Britain.

Buchanan-Smith, M. (1993). A Review of OXFAM's Approach to Relief Food Distribution in Samburu and Turkana Districts of Kenya, 1992/93: The Entitlements System, OXFAM.

Buchanan-Smith M. \& Simon Maxwell (1994). Linking Relief and Development: An Introduction and Overview. IDS Bulletin.

Brinkerhoff, D. W., \& Goldsmith, A. A. (1988). The Challenge of Administrative Reform in Post-Duvalier Haiti: Efficiency, Equity and the Prospects for Systemic Change. International Review of Administrative Sciences, 54, 89-114.

Brunsma, David L., Overfelt, David, \& Picou, J. Steven (2010). The Sociology of Katrina: Perspectives on a Modern Catastrophe. Rowman \& Littlefield Publishers, INC.

Bush, Jennifer (1995). The Role of Food Aid in Drought and Recovery: Oxfam's North Turkana (Kenya) Drought Relief Programme, 1992-94. Disasters. Volume 19, Issue 3, Pp 247-259.

Cederlöf, Gustav; Kingsbury, Donald V. (2019). "On PetroCaribe: Petropolitics, Energopower, and Post-Neoliberal Development in the Caribbean Energy Region". Political Geography. 72: 124-133.

Charles, Jean Max (2002). Psycho-sociological Analysis of Political Uprising and Violence in Haiti from (1986-1991). Thesis presented for the Title of License in Sociology, Haiti State University.

Charles, Jean Max (2020). The Slave Revolt that Changed the World and the Conspiracy Against it. The Haitian Revolution and the Conspiracy Against It. Journal of Black Study. Vol. 51 (4). 275-294. 
Chao, Li-Wei et al. (2012). A Comparison of EPI Sampling, Probability Sampling, and Compact Segment Sampling Methods for Micro and Small Enterprises. Journal of Development Economics. Vol. 98 (2012) 94- 107.

Christoplos, Ian (2003). Actor at Risk in Pelling, Mark (2003). Natural Disasters and Development in a Globalizing World. Routledge.

Christoplos, Ian (2006). Links Between Relief, Rehabilitation, and Development in the Tsunami Response: A Synthesis of Initial Findings. Overseas Development Institute.

Church, Jeen-Chuan \& Liu, Ching-Tsung (2014). Morakot Post-disaster Reconstruction Management Using Public and Private Resources for Disaster Prevention and Relief efforts. Journal of the Chinese Institute of Engineering.

Crémieux, Beaulieu (1996). Privatisation des Entreprises d'État en Haïti : Rapport de Mission. Centre Canadien d'Etude et de Coopération Internationale.

C-Span (2010). United Nations Haiti's Donors Conference. Sources: https://www.cspan.org/video/?292805-1/united-nations-haiti-donors-conference. Retrived on June 7, 2020.

Davis, Ian (2008). Progress in Analysis of Social Vulnerability and Capacity in Bankoff, Greg; Frerks, Georg Frerks; and Hilhorst, Dorothea (2008). Mapping Vulnerability: Disasters, Development \& the People. Earthscan.

Degnbol-Martinussen, John \& Engberg-Pedersen (2005). Aid: Understand National Development Cooperation. Zed Books Ltd. London. New York.

Delica-Willison, Zenaida and Willison, Robin (2008). Vulnerability Reduction: A task for the Vulnerable People Themselves in Bankoff, Greg; Frerks, Georg Frerks; and Hilhorst, Dorothea (2008). Mapping Vulnerability: Disasters, Development \& the People. Earthscan.

Desroches, \& al. (2011). Overview of the 2010 Haiti Earthquake. Earthquake Spectra, Volume 27, No. S1, pages S1-S21,

Dillon, E. M \& Drexler (2016). The Haitian Revolution and the Early United States: Histories, Textualities, Geographies. University of Pennsylvania Press.

Dore, Mohammed H.I. \& Etkin, David (2003). Natural Disasters Adaptive Capacity and Development in the twenty first Century in Pelling, Mark (2003). Natural Disasters and Development in a Globalizing. World. Routledge. 
Drabek, Anne Gordon (1987). Development Alternatives: The Challenge for NGOs: An Overview of the Issues. World Development, Vol 15.

Dreze, J. \& Sen, A. (1989). Hunger and Public Action. Clarendon Press. Oxford.

Dube, Ernest (2020). The Build-back-better Concept as a Disaster Risk Reduction Strategy for Positive Reconstruction and Sustainable Development in Zimbabwe: A Literature Study. International Journal of Disaster study Risk Reduction.

Duffield, Mark (2010). The Liberal Way of Development and the Development-Security Impasse: Exploring the Global Life-Chance Divide. Sage Publication. Vol. 41 (1) 53-76.

Dupuy, Alex (2005). Globalization, the World Bank, and the Haitian Economy in Knight, Franjklin W. \& Martinez-Vergne, Teresita (2005). Contemporary Caribbean Cultures and Societies in a Global Context. The University of Carolina Press.

Dupuy, Alex (2014). Haiti, From Revolutionary Slaves to Powerless Citizens: Essays on the Politics and Economics of Underdevelopment, 1804-1813.Roultledge.

Embassy of the Republic of Haiti in Washington DC (ERHW). Haiti at a Glance. https://www.haiti.org/haiti-at-a-glance/ Retrieved on June 6, 2020.

ECVMAS (2002). Enquête sur les Conditions de Vie des Ménages Après le Séisme (Survey on the Living Conditions of Households After the Earthquake) IHSI.

Etienne, Hadlaire (2010). Dilemmes et Enjeux des Privatisations des Entreprises Publiques pour l'Etat Haitien. Master Thesis. Quebec University at Montreal.

Escobar, Arturo (1995). Encountering Development: the making and unmaking of the third world. Princeton University Press.

Fatton, Robert (2007). The Root of Haitian Despotism. Lynne Rienner Publisher.

Fatton, Robert Jr. (2013). Michel-Rolph Trouillot's State Against Nation: A Critique of the Totalitarian Paradigm. Small Axe, Inc, Vol. 42.

Farmer Paul (2006). The Uses of Haiti. Common Courage Press. Third Ed. Canada.

Ferguson, James (1987). Papa Doc, baby Doc: Haiti and the Duvaliers. Basil Blackwell Ltd.

Ferguson, James (2006). Global Shadows: Africa in the Neoliberal World Order. Duke University Press. 
Fisher Henry W. (1998). Response to Disaster, Fact Versus Fiction: The Sociology of Disaster. University Press of America.

Galway Lindsay P., Corbett, Kitty K. \& Zeng, Leilei (2012). Where are the NGOs and why? The Distribution of Health and Development NGOs in Bolivia.

Globalization and Health.

GOH (2010). Haïti PDNA du Tremblement de Terre - Evaluation des Dommages, des Pertes et des Besoins Généraux et Sectoriels : Annexe du Plan d'Action pour le Relèvement et le Développement National d'Haïti. $G O H$.

Goldin, Ian (2016). The Pursuit of Development: Economic Growth, Social Change, and Ideas. Oxford University Press.

Grenier, Guillermo J. \& Morrow Betty H. (1997). Before the Storm: The Socio-Political Ecology of Miami in Peacock Gillis W., Morrow Betty H., Gladwin, Hugh (1997) Hurricane Andrew: Ethnicity, Gender and the Sociology of Disasters. Routledge: London. New York.

Grove, Kevin (2013). Insuring "Our Common Future": Dangerous Climate Change and the Biopolitics of Environmental Security. Geopolitics, 15:536-563.

Grove, K. (2013). Hidden Transcripts of Resilience: Power and Politics Jamaican Disaster Management. Resilience, 1(3): 193-209.

Grove, K. 2014. Agency, Affect, and the Immunological Politics of Disaster Resilience. Environment and Planning D: Society and Space. Vol. 32: 240-256.

Grünewald, F., and B. Renaudin. 2010. Etude en Temps Réel de la Gestion de la Crise en Haïti Après le Séisme du 12 Janvier 2010 : Mission du 9 au 23 février 2010. Mission Report, Delegation of Strategic of Affairs of the Ministry of Defense, Republic of France, 4 April.

Haddon, W., Suchman, E. A. \& Klein, D. (1964). Accident Research: Methods and Approaches. New York. Harper \& Row.

Haiti Libre (2013). Haiti - Economy: The Amount of Remittances in Haiti has Doubled in 10 Years. HaitiLibre.com

Heinl R. D. and Heinl N G. (2005). Written in the Blood: The Story of the Haitian People 1492-1995. University Press of America. Maryland.

Hejimans, Annelies (2008). From Vulnerability to Empowerment in Hilhorst, Dorothea (2008). Complexity and Diversity: Unlocking Social Domains Disaster Bankoff, 
Greg; Frerks, Georg Frerks; and Hilhorst, Dorothea (2008). Mapping Vulnerability: Disasters, Development \& the People. Earthscan.

Hejiman, A. \& Victoria, L. (2001). Citizenry-Based and Development-Oriented Disaster Response: Experience and Practice in Disaster Management of the Citizen Disaster Response Network in Philippines. Center for Disaster Preparedness. Manilla.

Hewitt, K. (1983). Interpretations of Calamities from the Viewpoints of Human Ecology, Allen and Unwin Inc, London.

Hewitt, K. (1995). Sustainable Disasters? Perspectives and Power in the Discourse of Calamity, in J. Crush (ed.) Power and Development., Routledge, London and New York, pp 115-28.

Hewitt, K. (1997). Regions at Risk: A Geographical Introduction to Disasters. Routledge

Heywood, Andrew (1994). Political Ideas and Concepts. An Introduction, London, Macmillan.

Huntington, Ellsworth. (1945). Mainsprings of Civilizations. New York: Wiley

Kuhn, T. D. (1962). The Structure of the Scientific Knowledge. Chicago University Press.

Haiti Info (1995). Privatization: What the Haitian People Can Expect? Haiti Info. Vol. 3, No. 10.

Hallward, Peter (2007). Damming the Flood: Haiti, Aristide and the Politics of Containment. London, Verso.

Heywood, Andrew (1994). Political Ideas: An Introduction. London, Macmillan.

Hintzen, Percy (1989). The Cost of Regime Survival: Racial Mobilization, Elite Domination and the Control of the State in Guyana and Trinidad. Cambridge University Press.

Hintzen, Percy (1995). Structural Adjustment and the New International Middle-Class" Transition. Vol 24. Pp 53-73.

Hintzen, Percy (2014). After modernization: Globalization and the African dilemma in Modernization as Spectacle in Africa. Pp. 2 - 39, in Peter J. Bloom, Takyiwaa Manuh, and Stephan Miescher(2014). Modernization as Spectacle in Africa. Eds. Indiana University Press. 
Hintzen, Percy (2018). Rethinking Identity, National Sovereignty and the State: Reviewing some Critical Contributions. Social Identities, 2018 Vol. 24, No. 1, $39-47$.

Hintzen, Percy (2018). Towards a New Democracy in the Caribbean: Local Empowerment and the New Global Order in Meeks, Brian \& Quinn, Kate (2018). Beyond Westminster in the Caribbean. Ian Randle Publishers.

Hintzen, Percy (2019). Precarity and the HIV/AIDS Pandemic in the Caribbean: Structural Stigma, Constitutionality, Legality in Development Practice. Global Public Health.

IFRC (2019). Country Acceleration Plan 2019 - Haiti - Haiti | Relief Web https://reliefweb.int/report/haiti/ifrc.

International Crisis Group (2009). Haiti 2009: Stability at Risk. Latin America and Caribbean Briefing $\mathrm{N}^{\circ} 19$ Port-au-Prince/Brussels.

ISDR (2004). Living with Risk: A Global Review of Disaster Reduction Initiatives. UN Publications.

Janse, Harmen \& Flier, Kees V. D. (2014). Cordaid's Post Disaster Shelter Strategy in Haiti: Linking Relief and Development. Open house International. Vol. 39. No 3.

Klarreich, Kathie \& Polman, Linda (2010). The NGO Republic of Haiti. The Nation.

Kreutzmann, H Schütte S (2011). Linking Relief and Development in Pakistanadministered Kashmir. Mountain Research and Development.

Lavell, A (1994). Prevention and Mitigation of Disasters in Central America: Vulnerability to Disasters at a local Level, in Varley A. Disasters, Development, and Environment, Wiley, Manchester, pp. 133-59.

Landman, T. \& Abraham, M. (2004). Evaluation of Nine Human Rights Organizations. The Hague : Ministry of Foreign Affairs.

Lebrun, Marc-Evens (2018). Pharmacie Ambulante, un Risque Majeur de Santé Publique en Haïti. Loop.

Le Nouvelliste (2009). Les Moulins d'Haïti : Première Entreprise Recensée. Le Nouvelliste.

Le Nouvelliste (2015). Un Recensement Dénombre plus de 70000 Agents dans la Fonction Publique Haïtienne. Le Nouvelliste. 
Leibenstein, H. (1957). Economic Backwardness and Economic Growth. Wiley. New York.

Lizarralde, Gonzalo (2002). Organizational Design, Performance and Evaluation of PostDisaster Reconstruction Projects. Research Gate.

Lewis, David (2003). NGOs, Organization Culture, and Institutional Sustainability. The Annals of the American Academy of Political and Social Science, Vol. 590, Rethinking Sustainable Development, pp. 212-226

MacFadden, David (2017). Haiti to Rebuild National Palace smashed in 2010 earthquake. AP News.

Malilay, J., Brogan, D., and Flanders, W. D. (1996). A Modified Cluster-Sampling Method for Post-Disaster Rapid Assessment of Needs. Bulletin of the World Health Organization 1996 ; 74(4): 399-405.

McEloy, Ann \& Townsend, Patricia K. (2015). Medical Anthropology in Ecological Perspective. 6 ed. Taylor \& Francis Group.

McMichael, Philip (2012). Development and Social Change: A Global Perspective. Sage.

Martinussen, John D \& Pedersen Poul E. (2005). Understanding International Development Cooperation. Zedbooks, London.

Meehan, Kevin (2004). Haiti's Predatory Republic: The Unending Transition to Democracy by Robert Fatton, Jr. (review). The Latin Americanist. Volume 48, Number 1, Fall 2004, pp. 92-95 (Review).

Microtrends (2020). Port-au-Prince, Haiti Metro Area Population 1950-2020. https://www.macrotrends.net/cities/21133/port-au-prince/population retrieved on June 7, 2020.

Mitlin, D. et al. (2005). 'Reclaiming Development? NGOs and the Challenges of Alternatives'. Background Paper for Third Manchester Conference on NGOs.

Mmembe, Achille (2017). Critique of Black Reason. Duke University Press.

Moral, Paul (1961). Le Paysan Haitien. Etude sur la Vie Rurale en Haiti. Ed. Fardin.

Mosel, Irina \& Levine, Simon (2014). Remaking the Case for Linking Relief, Rehabilitation and Development. Federal Ministry for Economic Cooperation and Development. 
Mother Earth Travel (MET) (2020). http://motherearthtravel.com/haiti/population.htm Retrieved on June 7, 2020.

Nwankwo, Ifeao C. K. (2008). "Charge with Sympathy for Haiti”: Harshening the Power of Blackness and Cosmopolitanism in the Wake of the Haitian Revolution. Pp 91113 in Tree of Liberty: Cultural Legacies of the Haitian Revolution. Virginia University Press, Virginia.

Nurkes, R. (1953). Problem of Capital Formation in Under-Developed Countries. Oxford University Press.

OECD (Organization for economic Cooperation and Development) (2004a). Assessment Framework for Coverage of Humanitarian Action in Peer Review (Paris: OECD).

Oakley, P. \& Floke, S. (1999a). The Danish NGOs Impact Study: A Review of Danish NGOs Activities in Developing Countries. Synthesis Report. Copenhagen: Danida, Ministry of Foreign Affairs.

(OSGSA, 2010). Interim Haiti Recovery Mission: Background Information. http://www.lessonsfromhaiti.org/lessons-from-haiti/interim-haiti-recoverycommission/ Retrieved on June 7, 2020.

O’Loughlin, K. F., James, Lander F. (2003). Caribbean Tsunamis: A 500 years from 1498-1998. Springer Science.

Oliver-Smith, Anthony (2008). Theorizing Vulnerability in Bankoff, Greg; Frerks, Georg; Hilhorst Dorothea (2008). A Globalized World: A political Ecological Perspective in Mapping Vulnerability: Disasters, Development, \& the People. Earthscan.

Oliver-Smith, A. and Hoffman Susanna M. (2001). Theorizing Disasters: Nature, Power, and Culture in Hoffman, Susanna M. and Oliver-Smith, Antony (2001). Catastrophe and Culture: The Anthropology of Disasters. School of American Press Research. New Mexico.

Olopade, D. (2014). The Bright Continent: Breaking Rules and Making Change in Modern Africa. Houghton: Mifflin Harcourt.

Ong, Aihwa (1999). Flexible Citizenship: The Cultural Logics of Transnationality. Durham, N.C.: Duke University.

Otto, Ralf and L., Weingärtner (2013). Linking Relief and Development: More Than Old Solutions for Old Problems? Channel Research on Behalf of the Dutch Ministry of Foreign Affairs. IOB. 
Ozrerdeem, A. (2003). Manifestation of Unresolved Development Challenges in Pelling (2004) Natural Disasters and Development in a Globalizing World. Routledge.

Passport Health (2015). What Do I Need to Know About Cholera in Haiti?

https://www.passporthealthusa.com/2015/05/cholera-outbreak-in-haiti-protectyourself/1/7.

Pierre-Charles, Gerard (1973). Radiographie d'une Dictature : Haiti et Duvalier. Nouvelle Optique. Montreal.

Pierre Etienne, Sauveur (1997). Haiti : L'Invasion des ONGs. Les Editions CIDIHCA.

Pierre-Louis, Francois. (2011). Earthquakes, Nongovernmental Organizations, and Governance in Haiti. Journal of Black Studies, Vol. 42, No 2, pp. 186-202.

Peet, R. \& Hartwick, E. (2009). The Theories of Development: Contentions, Arguments, Alternatives. The Guilford Press, New York. London.

Polanyi, Karl (1957). The Great Transformation: The Political and Economic Origins of Our Time. Beacon Press.

Quarantelli, E L (1985). What is a Disaster? the need for Clarification and Conceptualization in Research, in Solomom S. (ed) Disasters and Mental Health Selected Contemporary Perspectives., US Government Printing Office, Washington, DC.

Quarantelli, E L (1991). More and Worse Disasters in the Future, Paper Presented at the UCLA International Conference on the Impact of Natural Disasters: Agenda for Future Action, Los Angeles, California, 10-12 July.

Rahnema, Majid \& Bawtree, Victoria (1997). The Post Development Reader. ZedBooks.

Ramet, Valerie (2012). Linking Relief, Rehabilitation and Development: Towards more Effective Aid. European Union Parliament, Policy Briefing.

Ramachandran, Vijaya \& Walz, Julie (2015). Haiti: Where has all the Money Gone? Journal of Haitian Studies, Vol. 21. No 1. Pp. 26-65.

Reid, Julian (2012). The Neoliberal Subject: Resilience and the Art of Living Dangerously. Pp143-165. Wiley.

Reimann, Kim D. (2006). A View from the Top: International Politics, Norms and the Worldwide Growth of NGOs. Political Science Faculty Publications. 
Reinhardt, Thomas (2005). 200 Hundred Years of Forgetting: Hushing up the Haitian Revolution. Vol. 35, No. 4.

Rencoret, Nicole (2006). Evaluating Humanitarian Action Using the OECD-DAC Criteria. ALNAP.

Reno, William (1999). Warlord Politics and African States. Boulder: Lynne Rienner Publishers.

Riddell, Roger C. (2007). Does Foreign Aid Really Work? Oxford University Press.

Riddell et al. (1997). Searching for Impact and Methods. NGO Evaluation Synthesis Study, Vol. 2 Department for International Development Cooperation. Ministries for Foreign Affairs of Finland.

Robert, Maguire (2008). The Roots of Haitian Despotism by Robert Fatton. Journal of Haitian Studies. Book Review.

Rostow, W (1960). The Stages of Economic Growth: A Non-Communist Manifesto, Cambridge. University Press. Cambridge.

Ross, J.; Maxwell, S. \& Buchanan-Smith M. (1994). Linking relief and Development. Institute of Development.

Sajinés, Javier (2007). The Nation: An Imagined Community. Cultural Studies. Vol. 21, Nos. 23 March/May 2007, pp. 295308.

Salamon, L. The Rise of the Non-Profit Sector. Foreign Affairs, Vol. 73, N0 4.

Salt, Julian E. (2003). The Insurance Industry: Can it Cope with Catastrophe? In Pelling Mark (2003). Natural Disasters and Development in a globalizing World. Routledge.

Scherer, J. (1912). Great Earthquakes in the Island of Haiti. Bulletin of the Seismological Society of America (1912) 2 (3): 161-180.

Schiller, Nina Glick \& Fouron, Georges (2001). Georges Wake up Laughing: LongDistance Nationalism and the Search for Home. Duke University Press.

Schipper, Lisa \& Pelling, Mark (2006). Disaster Risk, Climate Change and International Development: Scope for, and Challenges to, Integration. Disasters, 30(1): 19-38 Overseas Development Institute.

Schuller, Mark (2007). Invasion of Infusion? Understanding the Role of NGOs in Contemporary Haiti. Journal of Haitian Studies, Vol. 13.2 
Schuller, Mark. (2009). Gluing globalization: NGOs as Intermediaries in Haiti. Political Anthropology Review, Vol. 32, No 1, pp 84-104.

Schuller, Mark (2012). Killing with Kindness: Haiti, International Aid, and NGOs. Rutgers University Press.

Sen, Amartya (1999). Development as Freedom. Anchor Books, New York.

Singh, R. \& Barton-Dock, M. (2015). Haiti: Toward a New Narrative. Washington, DC: World Bank Group.

Sirleaf, E. J. (1993). "From Disaster to Development" in K. Cahill (ed.) A Framework for Survival: Health, Human Rights and Humanitarian Assistance in conflicts and Disasters, New York: Basic Books and the Council of Foreign Relations.

Shigetomi, Schinichi (2002). The State and the NGOs: Perspective from Asia. Institute of Southeast Asian Studies.

Smith Bronte (2013). The Role of Vegetation in Catastrophic Floods. A Spatial Analysis. University of Wollongong.

Smith, Brian (1998). "Nonprofit Organizations in International Development: agent of empowerment or Preservers of stability," in Powell, W. and Clemens E. (1998) Private Action and the Public Good, Ed, 212-27. New Haven, CT Yale University Press.

Strauss, A., \& Corbin, J. (1998). Basics of Qualitative Research: Techniques and Procedures for Developing Grounded Theory. Thousand Oaks, CA: Sage Publications, Inc.

Strudsholm, Tina (2016). Using Mixed Methods to Facilitate Complex, Multiphased Health Research. International Journal of Qualitative Methods.

Solovieve, S. L. (1978). Tsunamis. In UNESCO, pp118-39.

Tarp, Finn (2000). Foreign Aid and Development: Lessons Learnt and Directions for the Future. Routledge. New York.

Terry Eagleton (1991). Ideology. An Introduction. London.

Thompson, Chris \& Croke, Jacky (2013). Geomorphic Effects, Flood Power, and Channel Competence of a Catastrophic Flood in Confined and Unconfined Reaches of the Upper Lockyer Valley, Southeast Queensland, Australia. Research Gate. 
Thorbecke, Erik. (2006). The Evolution of the Development Doctrine and the Role of Foreign Aid. United Nations University.

Toblin, J. (1977). Disaster Prevention and Control in Earth Sciences. Impact of Science on Society, vol. 27, pp131-39.

Todoroki, Emiko, Vaccani, Matteo, \& Noor, Wameek (2009). The Canada-Caribbean Remittance Corridor: Fostering Formal Remittances to Haiti and Jamaica through Effective Regulation. The World Bank.

Trouillot, Michael-Rolph (2001). "The Anthropology of the State in the Age of Globalization: Close Encounters of the Deceptive Kind. Current Anthropology.

Twigg, John (2009). Characteristics of a Disaster-Resilient Community. Latitude Graphic Design.

United Nations (1987). Our Common Future: Report of the World Commission on Environment and Development. Commission on Environment.

United Nations (2002). Johannesburg Declaration on Sustainable Development. United Nations.

United Nations (2004). Living with Risk: A Global Review of Disaster Reductions Initiatives. International Strategy for Disaster Reduction (ISDR).

United Nations Department of Economic and Social Affairs, Statistical Office (1976). Population of capital and Cities of 100, 000 and More Inhabitants. Demographic Yearbook 1975. New York. pp. 253-279.

United Nations (2005). Investing in Development: A Practical Plan to Achieve the Millennium Development Goals. Earthscan.

United Nations (2010). Towards a New Future for Haiti. UN Chronicle.

United Nations (2017). Report of the Secretary-General on the United Nations Stabilization Mission in Haiti. United Nations Security Council.

UNDP (2015) A Cuban Model for a Resilient Caribbean. United Nations Development Programmes.\%20Cuban\%20model\%20for\%20a\%20resilient\%20Caribbean $\% 20$ $\%$ 20UNDP.htm

UNDP (2019). Inequalities in Human Development in the 21st Century Briefing: Note for Countries on the 2019 Human Development Report (Haiti). UNDP.org. 
Verner, Dorte (2007). The Haitian People: Demographics, Poverty, and Socioeconomic Outcomes and Risks, in Social Resilience and State Fragility in Haiti. The World Bank.

Ward, Patrick S. \& Shively Gerald E. (2017) Disaster Risk, Social Vulnerability, and Economic Development. Disasters, Overseas Development Institute.

Wilentz, Amy (2019). The Other Notre-Dame Was Not Rebuilt: Perhaps France should Help Haiti, its Former Colony, Rebuild the Cathedral Lost in the 2010 Earthquake. The Atlantic.

West, Madeline (2014). Community Water and Sanitation Alternatives in Peri-Urban Cochabamba: Progressive Politics or Neoliberal Utopia? Master Thesis. School of International Development Studies. Faculty of Social Sciences University of Ottawa.

World Bank (1995). Working with NGOs A Practical Guide to Operational Collaboration between the World Bank and Non-Governmental Organizations. Operations Policy Department, World Bank, pp.7-9.

World Bank (1996): Country Assistance Strategy of the World Bank Group for the Republic of Haiti. The World Bank Group.

World Bank (1998). Haiti: The Challenge of Poverty Reduction. Report No 17242-HA

World Bank (2002). 'Haiti: Country Assistance Evaluation'. Washington, DC: Operations Evaluation Department, The World Bank.

World Bank (2003). Poverty and Climate Change: Reducing the Vulnerability of the Poor through Adaptation. The World Bank.

World Bank (2007). The Haitian People: Demographics, Poverty, and Socioeconomic Outcomes and Risks in Social Resilience. The World Bank.

World Bank. (2018, April 2). The World Bank in Haiti. Overview. Retrieved from http://www.worldbank.org/en/ country/haiti/overview.

World Bank (2020). https://www.worldbank.org/en/country/haiti/overview. Retrieved on June 7, 2020.

World Population (2020). http://worldpopulationreview.com/countries/haiti-population . Retrieved on June 2020.

World Bank (2020). GDP Growth (annual \%) - Haiti. Worldbank.org. 
Wisner, Ben (2008). Assessment of Capability and Vulnerability in Bankoff, Greg; Frerks, Georg Frerks; and Hilhorst, Dorothea (2008). Mapping Vulnerability: Disasters, Development \& the People. Earthscan.

World Statistical Data (2019). https://populationstat.com/haiti/port-au-prince. Retrived on June 6, 2020.

Zanotti, Laura (2010). Cacophonies of Aid, Failed State-building and NGOs in Haiti: Setting the Stage for Disaster, Envisioning the Future: Third World Quarterly, Vol.31(5), pp.755. 


\section{Appendix}

\section{Household Survey in Port-au-Prince, Haiti}

Objectif of the Survey : Answer the question: To what extent was disaster resilience built into the post-quake NGOprovided relief in Haiti?

\section{Part I: Demographic and General Context of the City}

\begin{tabular}{|c|c|}
\hline A. Location & \\
\hline $\begin{array}{l}\text { A1. Municipality/Commune } \\
\text { (__ })\end{array}$ & 1=Delmas $\quad 2=\mathrm{P}-\mathrm{au}-\mathrm{P} \quad 3=$ Carrefour \\
\hline \multicolumn{2}{|l|}{ A2. Name of the commune } \\
\hline \multicolumn{2}{|l|}{ A3. Address : } \\
\hline $\begin{array}{l}\text { A4. Do you agree to participate in the survey? } \\
\text { (__ ) }\end{array}$ & $\begin{array}{l}1=\text { Agree } \\
2=\text { Decline (If declined take the GPS coordinates and end of the } \\
\text { survey) }\end{array}$ \\
\hline
\end{tabular}

\section{B. Household information}

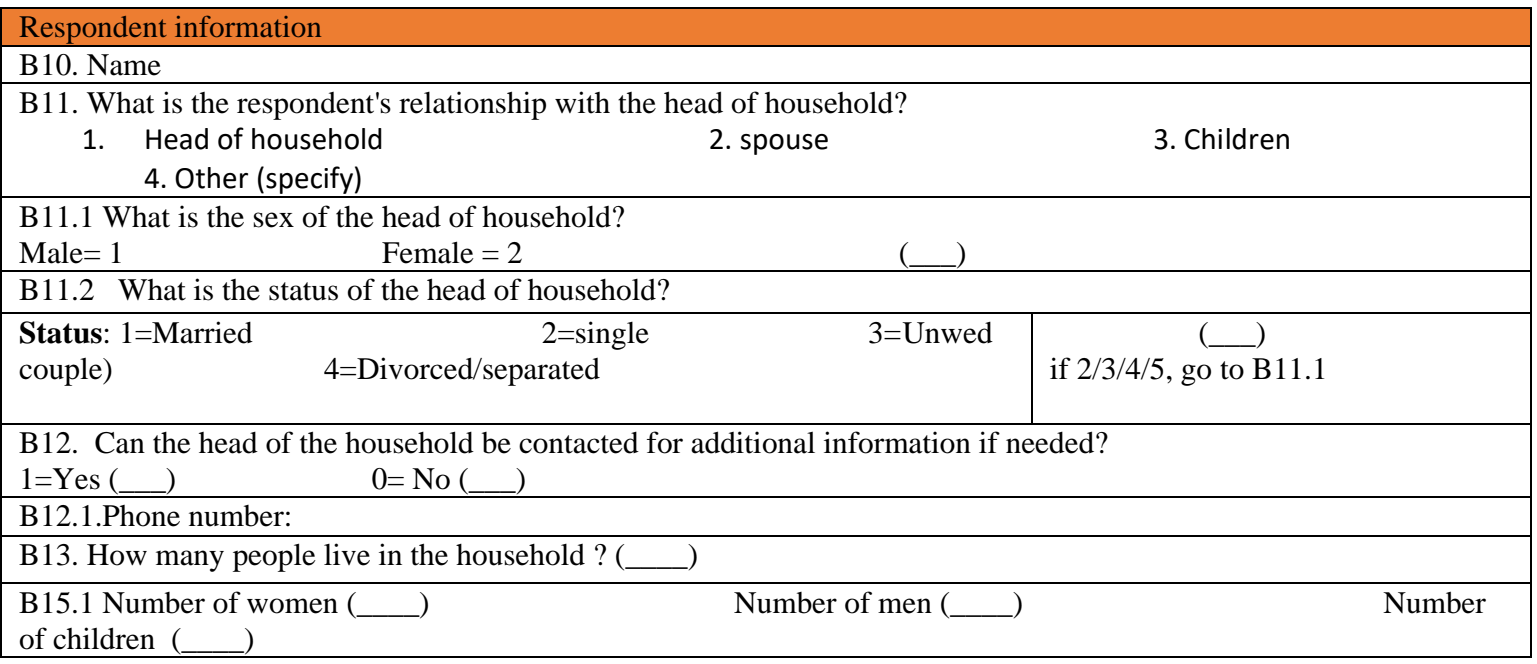




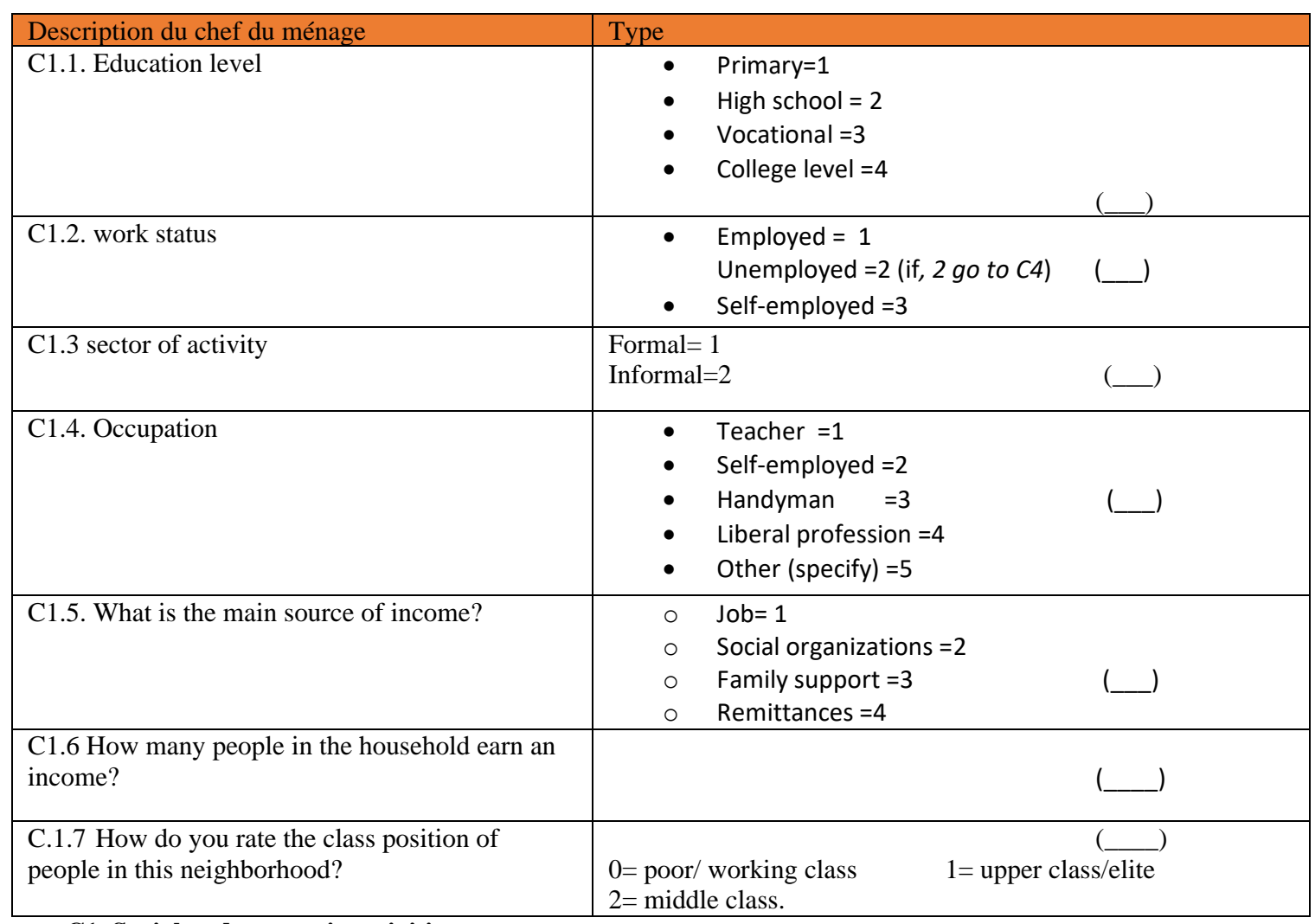

\section{C1. Social and economic activities}

\section{Part II. Risks Identified and Frequencies}

\section{Damages / life perturbation}

D1. Have you exposed to the January 12, 2010 earthquake? (__ ).

D1.1 How many times have you been exposed to natural disasters (earthquake, cyclone or flood, etc.) during your life? (_)

D2. How do you evaluate the losses resulting from the earthquake of January 12, 2010 (read the response modalities)

$0=$ No loss at all; $1=$ some losses ; 2 = much losses ; $\quad 3=$ lost everything

D3. Did you lose any members of your household during the 2010 earthquake?

$$
1=\text { Yes (_) ; } \quad 0=\mathrm{No}(\ldots) \text { (if no, go to D3.2) }
$$

D3.1. if 1 how many? (_ $)$;

D3.2. Did you (or any member of the household) lose your job after the January 12, 2010 earthquake?

$1=$ Yes ; (_ $\quad 0=$ No $\left(\_\right)$

D4. Is there anyone in your household who has long-term health problems as a result of the 2010 earthquake? $1=$ Yes ; (_ $) \quad 0=\mathrm{No}\left({ }^{\prime}\right)$

D.5 What is the threat of natural disasters most feared by people in your community?

Earthquake $=1 ; \quad$ Hurricane $=2$ Tropical Storm $\quad$ Landslide $=4$; Flood $=4$;

Epidemic $=5$

Other $($ Explain $)=6 ; \quad$ Do not know $=7$

D.6. How do you evaluate the financial losses resulting from January 12, 2010? 


\begin{tabular}{|c|c|}
\hline $\begin{array}{r}\text { a) } \\
1=25 \% \\
2=50 \% \\
3=75 \% \\
4=\text { Tout }\end{array}$ & $\begin{aligned} \text { b) income } \\
1=25 \% \\
2=50 \% \\
3=75 \% \\
4=\text { Tout }\end{aligned}$ \\
\hline
\end{tabular}

\section{Part III: Recuperation et intervention}

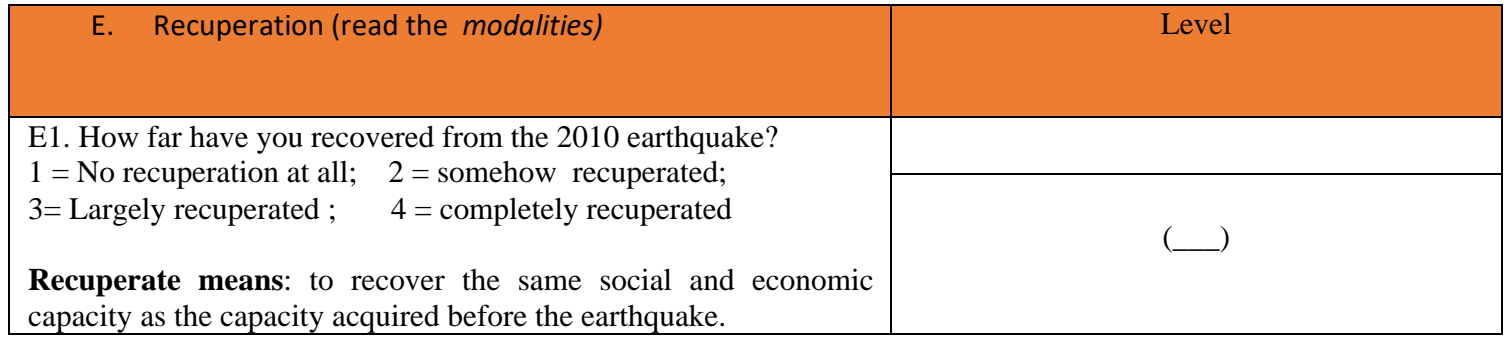

\section{Impact of the Intervention}

E2. Before the earthquake of January 12, 2010, what was the main source of household income
E3. How is this main source of income affected by the earthquake?

$1=$ Totally or almost totally affected (more than 70\%)

$2=$ more or less affected $(40 \%-70 \%)$

$3=$ Not very affected (less than $40 \%$ ) $4=$ Not affected $(0 \%)$

\begin{tabular}{|c|c|}
\hline a. (_) & $4=$ Not affected $(0 \%)$ \\
\hline
\end{tabular}

Code

$1=$ Salary/work

$2=$ permanent (with regular salary)

3 = Manufacture / sale of handicrafts

$4=$ Sale of prepared food

$5=$ Trade and services

$6=$ Transportation
E4. Currently, What is the main source of income (activity) of the household?
E5. Currently, how much of your total income does this source represent? (The total must not be greater than $100 \%$ )
$7=$ Domestic

services

$8=$ Tourism / Hotel /

Restaurant

9 = Construction

(bricklayer, carpenter)

10 Remittances

$11=$ Other

$99=$ No other sources 


\begin{tabular}{|c|c|c|}
\hline F. Intervention & & Agents \\
\hline $\begin{array}{l}\text { F1. F1. Who has contributed much to your recovery? } \\
\begin{array}{ll}1=\text { NGOs } ; & 2=\text { Gov. } ; \quad \text { Remittances }=3 ;\end{array}\end{array}$ & 4=None (go to F3) & $(\ldots)$ \\
\hline $\begin{array}{l}\text { F2. How did you use the assistance? } \\
1=\text { Food expenses } \quad 2=\text { for access to basic services. } \\
3=\text { Pay for education } \\
\text { rebuild house } \\
5=\text { Recapitalization } \\
\text { (specify) }\end{array}$ & $\begin{array}{l}4=\text { repair or } \\
6=\text { other }\end{array}$ & $\begin{array}{l}(\ldots) \\
([) \\
([)\end{array}$ \\
\hline
\end{tabular}

F3. How do you evaluate your socio-economic situation?

$1=$ Worse than before the January 12, 2010 earthquake

$2=$ Same as before the earthquake of January 12, 2010 (go to $\mathrm{G})$

$3=$ Better than before the earthquake of January 12, 2010 (go to $\mathrm{G})$

F4. After the earthquake, was your household affected by a negative event? (name in order of importance the 3 main shocks or events that affected you)

1. (_)

2. (_)

3. (_)

1= Landslide

$2=$ Flood

a family member

$3=$ Insecurity/Kidnapping

4= Fire/looting during political uprising

equipment and tool prices

5 =Land spoliation

food prices

$6=$ Illness or accident of a member of the household

7 = Deportation of a family member from abroad

affected at all
$8=$ death of

$10=$ Rising

$11=$ Rising

$12=$ Other

$13=$ Not

\section{Part IV. Resilience Assessment}

I define resilience as the social, economic and environmental arrangements that allow a community or country to resist natural events and rebound when they occur. These arrangements include appropriate municipal infrastructure, environmental protection, a robust public health system and women's integration, increased financial capacity, education promotion and disaster awareness, as well as to reduce risks, prepare for and respond to disasters. 
Based on this definition and the socio-economic and environmental conditions of Haiti, this research will assess the level of resilience based on seven key indicators: infrastructure, reforestation, public health, disaster awareness, financial resources, integration of the problematic women, risk reduction and preparedness.

\begin{tabular}{|c|c|c|c|c|}
\hline \multicolumn{3}{|c|}{$\begin{array}{l}\text { SECTION G: STRATEGIES FOR } \\
\text { SURVIVAL }\end{array}$} & & \\
\hline \multicolumn{2}{|c|}{$\begin{array}{l}\text { G1- } \\
\text { Since the earthquake, did one member of your household } \\
\text { for lack of financial means take any of the following } \\
\text { actions to cope with the shocks mentioned above? } \\
\text { (It is necessary mention the modalities of answer) }\end{array}$} & & $\begin{array}{l}\text { G1.1 } \\
1=\text { Yes (Go to next } \\
\text { question) } \\
0=\text { No (go to G2.2) }\end{array}$ & $\begin{array}{l}\text { G1.2 } \\
1=\text { No, } \\
\text { because I did } \\
\text { not run out of } \\
\text { food } \\
2=\text { No, } \\
\text { because I have } \\
\text { already sold } \\
\text { these assets or } \\
\text { conducted this } \\
\text { activity in the } \\
\text { past } 12 \\
\text { months and } \\
\text { cannot } \\
\text { continue } \\
\text { doing so } \\
3=\text { Not } \\
\text { applicable }\end{array}$ \\
\hline \multicolumn{2}{|c|}{$\begin{array}{l}\text { 1. Sold household goods (radio, furniture, television, } \\
\text { jewelry etc.) }\end{array}$} & & L & L \\
\hline \multicolumn{3}{|l|}{ 2. Spent his savings } & 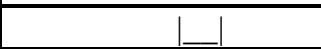 & 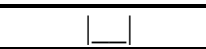 \\
\hline \multicolumn{3}{|c|}{$\begin{array}{l}\text { 3. Sent the household members to eat elsewhere (at a } \\
\text { family's house) }\end{array}$} & I & | \\
\hline \multicolumn{2}{|c|}{ 4. Bought food on credit or borrowed food } & & & $I$ \\
\hline \multicolumn{2}{|l|}{ 5. Borrowed money } & & & 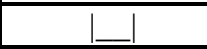 \\
\hline \multicolumn{3}{|c|}{ 6. Putting children in less expensive schools } & & $=$ \\
\hline \multicolumn{3}{|c|}{$\begin{array}{l}\text { 7. Has sold productive goods or means of transport (sewing } \\
\text { machine, carpentry tools cart, mechanical toolboxes, } \\
\text { generators, motorcycle car, etc.) }\end{array}$} & & 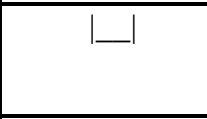 \\
\hline \multicolumn{2}{|c|}{ 8. Redraw kids from school } & & & $=$ \\
\hline \multicolumn{5}{|c|}{ 9. Reduced health (including drugs) and education costs } \\
\hline \multicolumn{5}{|c|}{ 10. Sold his house or a piece of land } \\
\hline \multicolumn{5}{|c|}{ 11. Beg (for food or money on the street) } \\
\hline \multicolumn{3}{|c|}{ 12. Migration of a member or the entire household } & & | \\
\hline \multicolumn{2}{|l|}{$\begin{array}{l}\text { 13. Other } \\
\text { (specify).. }\end{array}$} & & & | \\
\hline \multicolumn{5}{|l|}{ Resilience } \\
\hline $\begin{array}{l}\text { G2. Resilience } \\
\text { indicators }\end{array}$ & $\begin{array}{l}\text { G2.1. Evaluate the level of } \\
\text { improvement of the sub- } \\
\text { indicators. (If } 0 \text { or no } \\
\text { improvement, go to next } \\
\text { question) } \\
0=\text { no improvement at all } \\
1=\text { Slightly improve } \\
2=\text { Average level of } \\
\text { improvement } \\
\text { 3. Great improvement } \\
\text { Key question: Have you } \\
\text { noticed any improvement in }\end{array}$ & \multicolumn{3}{|c|}{$\begin{array}{l}\text { G2.2 Resilience distribution in percentage } \\
\text { If there is an improvement, who do you attribute } \\
\text { this improvement to? } \\
1 \text { = Gov. ; } 2 \text { = NGOs; } 3=\text { Other (explain) }\end{array}$} \\
\hline
\end{tabular}




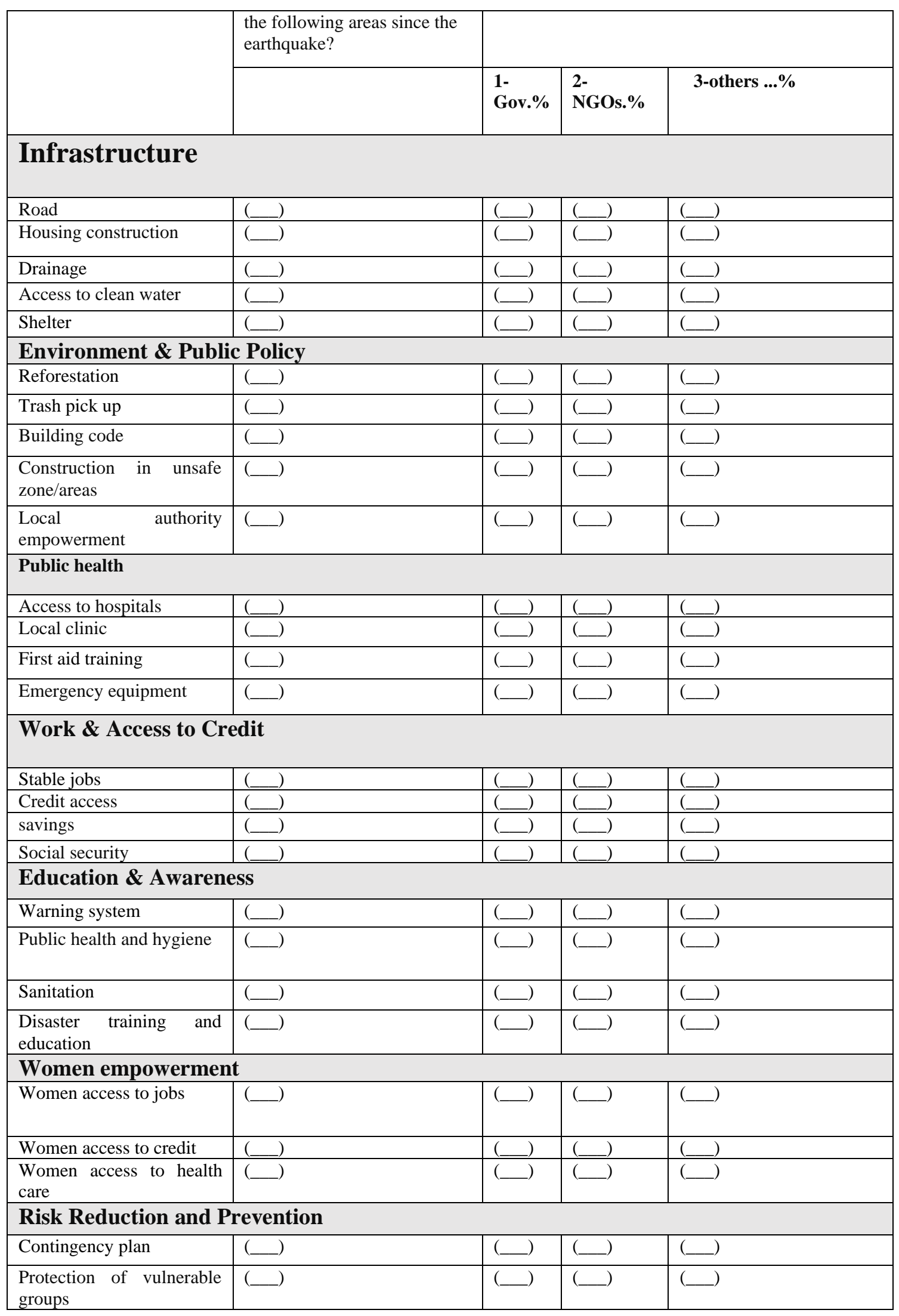




\begin{tabular}{|c|c|c|c|c|}
\hline $\begin{array}{l}\text { Emergency/rapid } \\
\text { intervention }\end{array}$ & $(\square)$ & $(\ldots)$ & $(\ldots)$ & $(\ldots)$ \\
\hline \multicolumn{5}{|c|}{$\begin{array}{l}\text { People's perception on the effectiveness of other countries to help in case of natural } \\
\text { disasters }\end{array}$} \\
\hline $\begin{array}{l}\text { According to your } \\
\text { opinion on } \\
\text { development, which of } \\
\text { these countries do you } \\
\text { think is the most } \\
\text { developed }\end{array}$ & $\begin{array}{l}\text { if a new natural disaster hits } \\
\text { Haiti, which of these } \\
\text { countries do you think might } \\
\text { be more effective in helping } \\
\text { the country? }\end{array}$ & $\begin{array}{l}\text { What is you } \\
\text { on the level } \\
\text { of these cou } \\
\text { protection } \\
\text { natural dis } \\
\text { Haiti? } \\
\mathrm{A}=\text { Favorab } \\
\mathrm{B}=\text { a little } \mathrm{f} \\
\mathrm{C}=\text { no supp }\end{array}$ & $\begin{array}{l}\text { opinion } \\
\text { support } \\
\text { tries for } \\
\text { against } \\
\text { ters in } \\
\text { orable } \\
t \text { at all }\end{array}$ & $\begin{array}{l}\text { Which of these countries would } \\
\text { you like to see helping in the } \\
\text { event of a disaster? }\end{array}$ \\
\hline$(\ldots)$ & $(\ldots)$ & $(\ldots)$ & & $(\ldots)$ \\
\hline \multicolumn{4}{|c|}{$\begin{array}{ll}1=\text { USA } & 2=\text { Canada } \\
4=\text { China } & \end{array}$} & $3=$ European Union \\
\hline \multicolumn{5}{|l|}{ Comments : } \\
\hline
\end{tabular}

Take the GPS coordinates, thank the respondent and end of the survey! 
VITA

\section{JEAN MAX CHARLES}

\section{EDUCATION}

1994-1999

1994-2002

2006-2009

2019-2020

2012-2015

2014-2020

2016-2019

2019-2020

2019-2020
Diplomas in Law

Haiti State University

School of Law and Economics

Port-au-Prince, Haiti

B.A. in Anthropology and Sociology

Haiti State University,

Port-au-Prince, Haiti

M.A. in Sociology

Florida International University

Boca Raton, Florida

Certificate in Theology and Ministry

Princeton University

Connecticut

Adjunct Professor of Sociology

Brown Mackie College

Miami, Florida

Doctoral Student

Florida International University

Miami, Florida

Teaching Assistant

Florida International University

Miami, Florida

Fulbright US Scholar

Haiti

Lecturer

Department of Human Sciences

Haiti State University

Port-au-Prince, Haiti 


\section{PUBLICATIONS}

Charles, Jean Max (2020). The Slave Revolt that Changed the World and the Conspiracy Against it: The Haitian Revolution and the Conspiracy Against. Journal of Black Studies.

Charles, Jean Max (2006). Voyage Inédit, Introduction in Lespérance, Jude (2016). Voyage Inédit. Amazon.

Charles, Jean Max (2001). (Sous-Développement et Mentalité Religieuse en Haiti) Underdevelopment and Religious Mentality in Haiti, Council of Gospel Churches, Haiti.

Charles, Jean Max (2001). (Ambivalence Cuturelle et Sous-Développement en Haiti) Cultural Ambivalence and Underdévelopment) in Haiti, Council of Gospel Churches, Haiti.

Charles, Jean Max (2012). Racial Conspiracy and the Transnational Impact of the Haitian Revolution: A Study of Race in a Global Context in The Failure of Ignorance. L'Oliver, New Jersey, Volume 23, Number One. 